\title{
ФЕДЕРАЛЬНАЯ СЛУЖБА ГОСУДАРСТВЕННОЙ СТАТИСТИКИ
}

\section{жИЛИщнОЕ Х0з:ЙСТВО В РоссиИ}

ОФИЦИАЛЬНОЕ ИЗДАНИЕ

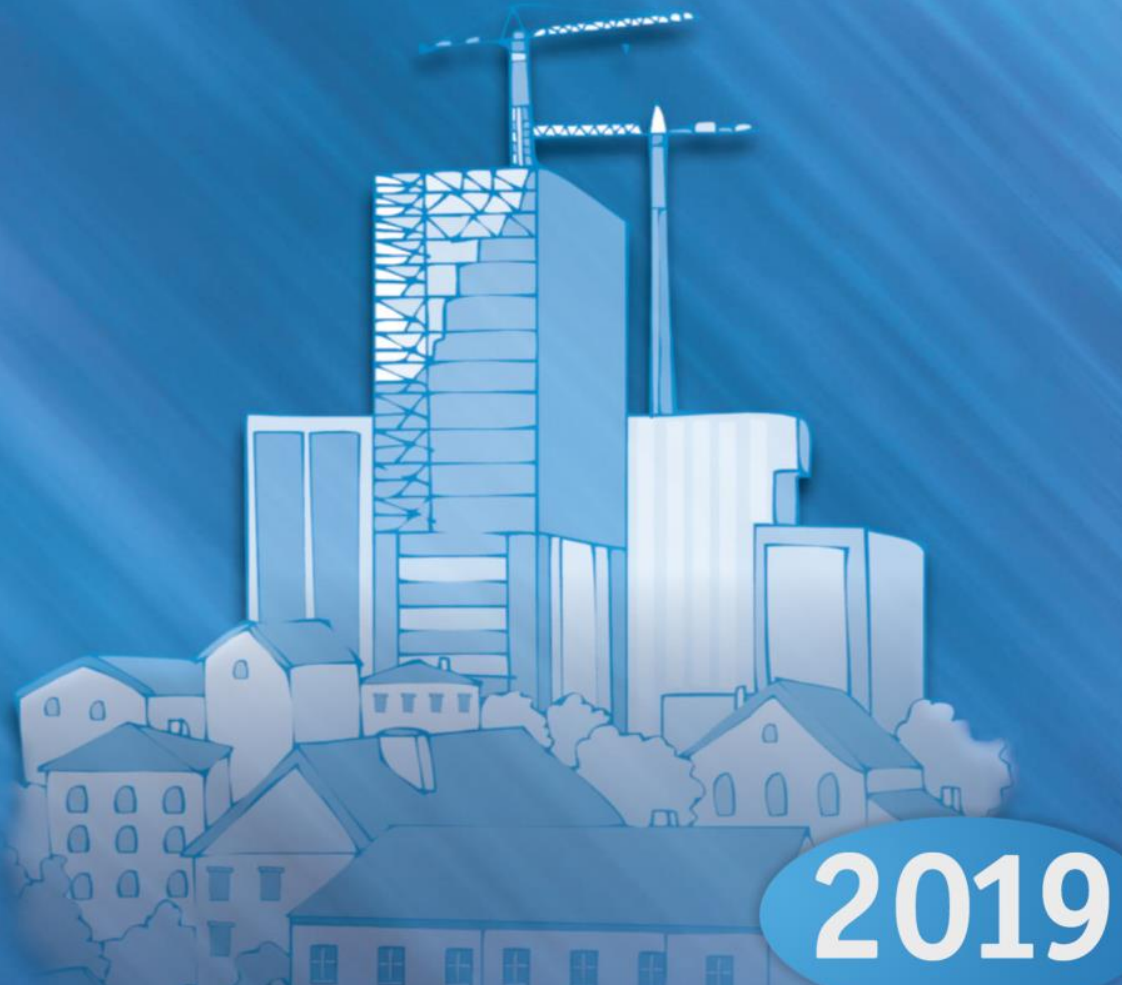


ФЕДЕРАЛЬНАЯ СЛУЖБА ГОСУДАРСТВЕННОЙ СТАТИСТИКИ (Росстат)

\section{ЖИЛИЩНОЕ ХОЗЯЙСТВО \\ В РОССИИ 2019}

Статистический сборник 
УДК 31:332.8(470)

ББК 65.051.5(2Poc)

Ж72

Редакционная коллегия:

И.Д. Масакова - Председатель редакционной коллегии

Н.А. Власенко - Заместитель председателя редакционной коллегии

И.В. Безрукавая, О.В. Борисова, Ю.А. Давыдова, Е.Е. Дехтяр, Л.Г. Ершкова, Д.С. Луконин, Г.Н. Ромашкина, М.А. Рязанова

Жилищное хозяйство в России. 2019: Стат. сб./ Росстат. -

Ж72 М., 2019. - 78 c.

ISBN 978-5-89476-475-7

В сборнике представлены основные показатели, характеризующие наличие и развитие жилищного хозяйства в Российской Федерации.

Для высшего управленческого персонала, руководителей и работников предприятий и организаций, научных, предпринимательских и банковских кругов, профессорско-преподавательского состава, аспирантов и студентов экономических вузов, других заинтересованных пользователей.

УДК 31:332.8(470) ББК 65.051.5(2Poc)

ISBN 978-5-89476-475-7

() Федеральная служба государственной статистики, 2019

E-mail: stat@gks.ru http://www.gks.ru 


\section{ПРЕДИСЛОВИЕ}

Статистический сборник содержит информацию о развитии жилищного хозяйства в Российской Федерации за 2010 - 2018 годы. Сборник издается с 2002 г. с периодичностью один раз в три года.

При подготовке сборника в разделах по жилищно-коммунальному хозяйству использованы данные, получаемые органами государственной статистики от юридических лиц, оказывающих жилищно-коммунальные услуги, федеральных органов государственной власти, имеющих жилищный фонд, принадлежащий на праве собственности Российской Федерации, органов государственной власти субъекта Российской Федерации, имеющих жилищный фонд, принадлежащий на праве собственности субъектам Российской Федерации, органов местного самоуправления, министерств и ведомств Российской Федерации.

В сборнике публикуются статистические данные, характеризующие жилищный фонд, его благоустройство, техническое состояние, распределение по формам собственности. Представлены данные о работах по ремонту и содержанию жилищного фонда. Сведения о работе сетей водоснабжения, теплоснабжения и канализации. О строительстве жилья и коммунальных объектов, объемах инвестиций, направленных на строительство новых и реконструкцию и модернизацию существующих объектов жилищно-коммунальной сферы, фринансово-экономическом состоянии организаций жилищно-коммунального хозяйства и энергосбережении в жилищно-коммунальном хозяйстве. Приводятся сведения о жилищных условиях населения и о реформе жилищно-коммунального хозяйства (субсидии, компенсации населению, дотации, цены на жилищно-коммунальные услуги), а также о первичном и вторичном рынках жилья. Представлены данные о реализации проектов и программ в сфере жилищнокоммунального хозяйства.

Данные по жилищному фонду с 2015 - 2018 годы сформированы не по полному кругу единиц учета, в связи с отсутствием нормативно-правового акта,устанавливающего порядок государственного учета жилищного фонда в Российской Федерации, в том числе его государственного технического учета (включая техническую инвентаризацию).

В связи с переходом с 1 января 2017 года на новые редакции общероссийских классификаторов видов экономической деятельности (ОКВЭД2) ОК 029-2014 и продукции по видам экономической деятельности (ОКПД2) ОК 034-2014 описание структуры российской экономики представлено в сборнике в соответствии с группировками этих классификаторов, которые разработаны Минэкономразвития России во исполнении «Плана мероприятий по формированию методологии систематизации и кодирования информации, а также совершенствованию и актуализации общероссийских классификаторов, реестров и информационных ресурсов».

ОКВЭД2 и ОКПД2 приняты и введены в действие приказом Росстандарта от 31.01.2014 № 14-ст (с изменениями).

Данные за 2018 год в ряде случаев являются предварительными.

Статистическая информация в разрезе субъектов Российской Федерации выделена в отдельное электронное приложение.

С 2016 г. статистический сборник «Жилищное хозяйство в России» издается только в электронном виде для размещения на официальном Интернет-сайте Росстата (http://www.gks.ru) в рубрике «Публикации». 


\section{ОТВЕТСТВЕННЫЕ ЗА РАЗДЕЛЫ СБОРНИКА}

Основные социально-экономические показатели

Состояние жилищного фонда

Жилищные условия населения

Строительство и рынок жилья

Инвестиции и финансовое состояние жилищно-коммунального хозяйства

Реализация программ в сфере жилищнокоммунального хозяйства

Международные сравнения
Л.Г. Ершкова

Г.С. Горнов

Г.С. Горнов

Г.Н. Ромашкина

А.М. Шадрин

С.Ю. Никитина

В.М. Тугушева

Е.А. Тарасенко

Е.Б. Фролова

Г.Н. Кириллова

А.М. Шадрин

И.В. Безрукавая

Г.Н. Кириллова

Г.С. Горнов

К.К. Зацепа

Г.Н. Кириллова

Е.Б. Фролова

В.М. Тугушева

А.М. Шадрин

К.Г. Оксенойт
Телефоны

(495) 607-4981

607-4981

607-4981

607-4262

607-4761

607-2605

$607-4761$

$607-4450$

$607-4801$

607-4447

$607-4761$

$607-2191$

607-4447

$607-4981$

$607-4686$

$607-4447$

$607-4801$

$607-4761$

$607-4761$

$607-4085$

\section{СОКРАЩЕНИЯ}

\begin{tabular}{llll} 
тыс. & - тысяча & кг & - килограмм \\
млн & - миллион & га & - гектар \\
млрд & - миллиард & кВт·ч & - киловатт - час \\
трлн & - триллион & Гкал & - гигакалория \\
м & - метр & г. & - год \\
м $^{2}$ & - квадратный метр & долл. - доллар \\
м $^{3}$ & - кубический метр & руб. & - рубль \\
пог. м & - погонный метр & р. & - раз \\
км & - километр & шт. & - штука \\
км & - квадратный километр & экз. & - экземпляр \\
\multicolumn{3}{r}{ В сборнике приняты условные обозначения: }
\end{tabular}

- явление отсутствует;

... данных не имеется;

0,0 значение показателя меньше единицы измерения.

В отдельных случаях незначительные расхождения между итогом и суммой слагаемых объясняются округлением данных. 


\section{СОДЕРЖАНИЕ}

Предисловие

\section{1. ОСНОВНЫЕ СОЦИАЛЬНО-ЭКОНОМИЧЕСКИЕ ПОКАЗАТЕЛИ}

1.1. Основные социально-экономические показатели

\section{2. СОСТОЯНИЕ ЖИЛИЩНОГО ФОНДА}

\section{Жилищный фонд}

2.1. Жилищный фонд

2.2. Распределение жилищного фонда по формам собственности

2.3. Распределение жилищного фонда по формам собственности (диаграмма)

2.4. Аварийный жилищный фонд

2.5. Распределение числа жилых домов (индивидуально-определенных зданий), числа многоквартирных жилых домов и общей площади жилых помещений по годам постройки в 2018 г.

2.6. Распределение числа жилых домов (индивидуально-определенных зданий), числа многоквартирных жилых домов и общей площади жилых помещений по материалу стен в 2018 г.

2.7. Распределение числа жилых домов (индивидуально-определенных зданий), числа многоквартирных жилых домов и общей площади жилых помещений по проценту износа в 2018 г.

\section{3. ЖИЛИЩНЫЕ УСЛОВИЯ НАСЕЛЕНИЯ}

\section{Обеспеченность населения жильем}

3.1. Численность населения Российской Федерации

3.2. Общая площадь жилых помещений, приходящаяся в среднем на одного жителя

3.3. Предоставление гражданам жилых помещений

3.4. Характеристика жилых квартир по числу комнат

\section{Благоустройство жилищного фонда}

3.5. Благоустройство жилищного фонда

3.6. Удельный вес общей площади жилых помещений, оборудованной одновременно водопроводом, водоотведением (канализацией), отоплением, горячим водоснабжением, газом или напольными электроплитами (график)

\section{Состояние инфраструктуры жилищного хозяйства}

3.7. Водоснабжение населенных пунктов ................................................ 19

3.8. Среднесуточный отпуск воды в расчете на одного жителя (график) ......... 20

3.9. Канализация населенных пунктов ...................................................... 20

3.10. Теплоснабжение населенных пунктов ................................................. 21

3.11. Наличие и состояние основных фондов организаций видов экономической деятельности, относящихся к жилищно-коммунальному хозяйству В $2010-2016$ гг.

3.12. Видовая структура основных фондов организаций видов экономической деятельности, относящихся к жилищно-коммунальному хозяйству в $2010-2016$ гг.

3.13. Наличие и состояние основных фондов организаций видов экономической деятельности, относящихся к жилищно-коммунальному хозяйству 
3.14. Структура наличия основных фондов коммерческих организаций (без учета субъектов малого предпринимательства) жилищнокоммунального хозяйства Российской Федерации по видам экономической

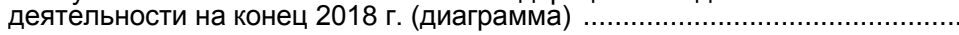

3.15. Видовая структура основных фондов организаций видов экономической деятельности, относящихся к жилищно-коммунальному хозяйству

3.16. Видовая структура основных фондов коммерческих организаций жилищно-коммунального хозяйства по видам экономической деятельности на конец 2018 г. (диаграмма)

\section{Благоустройство городских поселений}

3.17. Основные показатели внешнего городского благоустройства

\section{4. СТРОИТЕЛЬСТВО И РЫНОК ЖИЛЬЯ}

\section{Строительство жилья и коммунальных объектов}

4.1. Ввод в действие жилых домов

4.2. Индексы ввода в действие жилых домов (график)

4.3. Ввод в действие жилых домов организациями различных форм собственности и населением

4.4. Ввод в действие жилых домов в расчете на 1000 человек населения (график)

4.5. Ввод в действие жилых домов в городской и сельской местности

4.6. Темпы роста (снижения) ввода в действие жилых домов (диаграмма) ....

4.7. Строительство жилых домов по типам зданий (без жилых домов, построенных индивидуальными застройщиками)

4.8. Число построенных квартир и их средний размер

4.9. Средняя фактическая стоимость строительства одного квадратного метра общей площади жилых помещений во введенных в эксплуатацию жилых домах

4.10. Жилые дома, находящиеся в незавершенном строительстве .

4.11. Ввод в действие объектов коммунального хозяйства.

\section{Рынок жилья}

4.12. Оценка домохозяйствами состояния занимаемого ими жилого помещения по наличию и числу детей в возрасте до 18 лет ....

4.13. Распределение домохозяйств по намерению и источникам денежных средств для улучшения своих жилищных условий в 2018 г.

4.14. Оценка домохозяйствами состояния занимаемого ими жилого помещения в 2018 г.

4.15. Жилищные условия домохозяйств, имеющих детей в возрасте до 18 лет.

4.16. Предполагаемые источники денежных средств на покупку (строительство) жилья.

4.17. Приватизация жилищного фонда

4.18. Число зарегистрированных прав граждан и юридических лиц на жилые помещения на основании договоров купли-продажи.

4.19. Жилищные кредиты, предоставленные кредитными организациями физическим лицам 


\section{5. ИНВЕСТИЦИИ И ФИНАНСОВОЕ СОСТОЯНИЕ ЖИЛИЩНО-КОММУНАЛЬНОГО ХОЗЯЙСТВА}

\section{Инвестиции в жилищно-коммунальное хозяйство}

5.1. Инвестиции в жилые здания и помещения.

5.2. Инвестиции в основной капитал, направленные на развитие видов экономической деятельности, относящихся к коммунальному хозяйству ..

5.3. Индексы фризического объема инвестиций в основной капитал, направ-ленные на развитие видов экономической деятельности, относящихся к коммунальному хозяйству

\section{Финансовое состояние организаций жилищно-коммунального хозяйства}

5.4. Основные финансовые показатели работы организаций по виду экономической деятельности «Управление эксплуатацией жилого фонда» в $2010-2016$ гг.

5.5. Основные финансовые показатели работы организаций по виду экономической деятельности «Управление эксплуатацией жилого фонда за вознаграждение или на договорной основе»

5.6. Расходы консолидированного бюджета Российской Федерации на жилищно-коммунальное хозяйство.

5.7. Задолженность по финансовым обязательствам организаций, осуществляющих деятельность по управлению эксплуатацией жилого фонда

5.8. Структура суммарной задолженности организаций по виду экономической деятельности «Управление эксплуатациеи жилого фонда» в $2010-2016$ гг.

5.9. Структура суммарной задолженности организаций по виду экономической деятельности «Управление эксплуатацией жилого фонда за вознаграждение или на договорной основе»

5.10. Структура кредиторской задолженности организаций по виду экономической деятельности «Управление эксплуатацией жилого фонда» в $2010-2016$ гг.

5.11. Структура кредиторской задолженности организаций по виду экономической деятельности «Управление эксплуатацией жилого фонда за вознаграждение или на договорной основе»

5.12. Структура дебиторской задолженности организаций по виду экономической деятельности «Управление эксплуатацией жилого фонда» в $2010-2016$ гг.

5.13. Структура дебиторской задолженности организаций по виду экономической деятельности «Управление эксплуатацией жилого фонда за вознаграждение или на договорной основе»

5.14. Финансовые вложения организаций по виду экономической деятельности «Управление эксплуатацией жилого фонда» в $2010-2016$ гг.

5.15. Финансовые вложения организаций по виду экономической деятельности «Управление эксплуатацией жилого фонда за вознаграждение или на договорной основе»

\section{6. РЕАЛИЗАЦИЯ ПРОГРАММ В СФЕРЕ ЖИЛИЩНО-КОММУНАЛЬНОГО ХОЗЯЙСТВА}

6.1. Основные показатели государственной программы «Обеспечение доступным и комфортным жильем и коммунальными услугами граждан Российской Федерации»

6.2. Общая площадь капитально отремонтированных многоквартирных жилых домов и общие затраты на капитальный ремонт многоквартирных жилых домов 
6.3. Число многоквартирных жилых домов, в которых проведен капитальный ремонт и требующих капитального ремонта

6.4. Улучшение жилищных условий по отдельным категориям граждан

6.5. Улучшение жилищных условий участников Великой Отечественной войны

\section{Реформа жилищно-коммунального хозяйства}

6.6. Оплата населением жилищно-коммунальных услуг

6.7. Структура коммунальных платежей населения в 2018 г. (диаграмма) ........

6.8. Удельный вес расходов на оплату жилищно-коммунальных услуг в потребительских расходах домашних хозяйств .

6.9. Удельный вес расходов на оплату жилищно-коммунальных услуг в потребительских расходах домашних хозяйств в зависимости от уровня среднедушевых располагаемых ресурсов.

6.10. Индексы потребительских тарифов на отдельные группы и виды жилищно-коммунальных услуг .

6.11. Индексы потребительских тарифов (диаграмма)

6.12. Средние потребительские тарифы на отдельные виды жилищнокоммунальных услуг

6.13. Расходы на реализацию мер социальной поддержки граждан по обязательствам субъектов Российской Федерации и муниципальных образований на оплату жилья и коммунальных услуг в 2018 г.

6.14. Предоставление гражданам социальной поддержки по оплате жилого помещения и коммунальных услуг.

6.15. Среднемесячный размер социальной поддержки на одного пользователя (диаграмма)

6.16. Предоставление гражданам субсидий на оплату жилого помещения и коммунальных услуг

6.17. Среднемесячный размер субсидий на семью (диаграмма)

\section{Энергосбережение в жилищно-коммунальном хозяйстве}

6.18. Затраты организаций коммунального комплекса на мероприятия по энергосбережению.

6.19. Экономия, полученная организациями коммунального комплекса от проведенных мероприятий по энергосбережению

6.20. Число многоквартирных домов и квартир, оснащенных приборами учета потребляемых коммунальных ресурсов .

6.21. Объем отпуска коммунальных услуг, счет за которые выставлен по показаниям приборов учета

6.22. Удельный вес объема отпуска коммунальных услуг, счет за которые выставлен по показаниям приборов учета, в общем объеме отпуска коммунальных услуг

\section{7. МЕЖДУНАРОДНЫЕ СРАВНЕНИЯ}

7.1. Индексы физического объема платных услуг населению

7.2. Ввод в действие жилых домов

7.3. Число построенных квартир

7.4. Средний размер построенных квартир

7.5. Жилые помещения по видам благоустройства .................................... 70

Методологические пояснения 


\section{1. ОСНОВНЫЕ СОЦИАЛЬНО-ЭКОНОМИЧЕСКИЕ ПОКАЗАТЕЛИ}

\section{1. ОСНОВНЫЕ СОЦИАЛЬНО-ЭКОНОМИЧЕСКИЕ ПОКАЗАТЕЛИ}

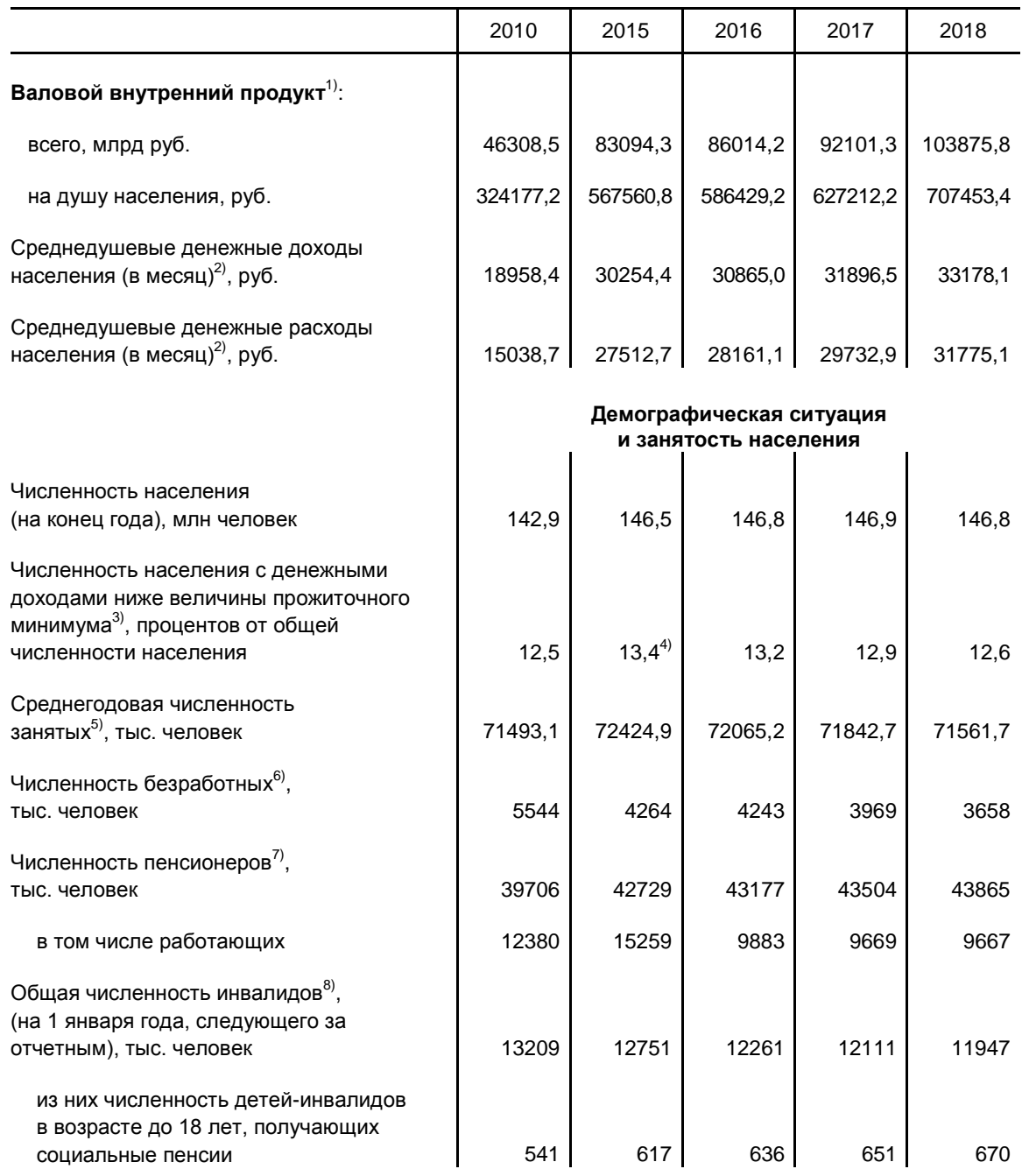


Продолжение табл.1.1

\begin{tabular}{l|l|l|l|l|l}
\hline & 2010 & 2015 & 2016 & 2017 & 2018 \\
\hline
\end{tabular}

\section{Жилищные условия населения}

Общая площадь жилых помещений:

$$
\text { всего, млн м² }
$$

в среднем на одного жителя, м²

Удельный вес общей площади, оборудованной одновременно водопроводом, канализацией, отоплением, горячим водоснабжением, газом или напольными электроплитами, процентов

Удельный вес аварийного жилищного фонда в общей площади всего жилищного фонда ${ }^{9)}$, процентов

Введено в действие жилых домов, млн м² общей площади жилых помещений

$$
\begin{aligned}
& \text { всего } \\
& \text { в том числе населением }
\end{aligned}
$$

Число приватизированных жилых помещений, тыс.

Число семей, состоявших на учете в качестве нуждающихся в жилых помещениях

всего, тыс.

в процентах от числа семей ${ }^{10}$

Число семей, получивших жилые помещения и улучшивших жилищные условия:

всего, тыс.

в процентах от числа семей, состоявших

\begin{tabular}{|c|c|c|c|c|}
\hline \multicolumn{5}{|c|}{ Жилищные условия и оплата жилья } \\
\hline 3231 & 3581 & 3653 & 3708 & 3780 \\
\hline 22,6 & 24,4 & 24,9 & 25,2 & 25,8 \\
\hline 62 & 66 & 66 & 67 & 67 \\
\hline 0,6 & 0,5 & 0,6 & 0,7 & 0,7 \\
\hline 58,4 & 85,3 & 80,2 & 79,2 & 75,7 \\
\hline 25,5 & 35,2 & 31,8 & 33,0 & 32,4 \\
\hline 885 & 449 & 225 & 165 & 95 \\
\hline 2821 & 2612 & 2542 & 2458 & 2364 \\
\hline 6 & 5 & 5 & 4 & 4 \\
\hline 244 & 135 & 129 & 123 & 99 \\
\hline 9 & 5 & 5 & 5 & 4 \\
\hline
\end{tabular}
на учете в качестве нуждающихся в жилых помещениях 
Продолжение табл.1.1

\begin{tabular}{l}
\hline \\
Численность лиц, страдающих тяжелыми \\
формами хронических заболеваний, \\
получивших жилое помещение \\
вне очереди, тыс. человек \\
Численность детей-сирот и детей, \\
оставшихся без попечения родителей, \\
получивших жилое помещение, \\
тыс. человек \\
Оплата жилья и коммунальных услуг
\end{tabular}

Удельный вес расходов на оплату жилого помещения и коммунальных услуг в потребительских расходах домашних хозяйств, процентов

Индекс физического объема,

в процентах к предыдущему году:

жилищно-коммунальные услуги

жилищные услуги

коммунальные услуги

Уровень возмещения населением затрат по предоставлению услуг, процентов

$$
\begin{aligned}
& \text { жилищно-коммунальных } \\
& \text { жилищных услуг } \\
& \text { коммунальных услуг }
\end{aligned}
$$

Начислено (предъявлено) жилищнокоммунальных платежей населению, млрд руб.

Фактически оплачено жилищно-

\begin{tabular}{|c|c|c|c|c|}
\hline 2010 & 2015 & 2016 & 2017 & 2018 \\
\hline 1,5 & 2,3 & 2,1 & 2,0 & 1,8 \\
\hline 10,6 & 19,1 & 20,4 & 23,1 & 22,9 \\
\hline 9,2 & 9,5 & 10,1 & 9,7 & 9,6 \\
\hline 104,7 & 98,7 & 100,2 & 103,4 & 100,7 \\
\hline 106,0 & 98,1 & 101,6 & 110,3 & 102,5 \\
\hline 103,5 & 99,6 & 99,5 & 101,0 & 99,9 \\
\hline 90 & 94 & 94 & 95 & 94 \\
\hline 85 & 96 & 99 & 99 & 99,6 \\
\hline 91 & 93 & 93 & 93 & 92 \\
\hline 1384,3 & 2126,6 & 2337,4 & 2501,1 & 2632,7 \\
\hline 1289,1 & 1990,8 & 2190,4 & 2392,5 & 2511,4 \\
\hline
\end{tabular}
коммунальных платежей населением, млрд руб. 
Продолжение табл.1.1

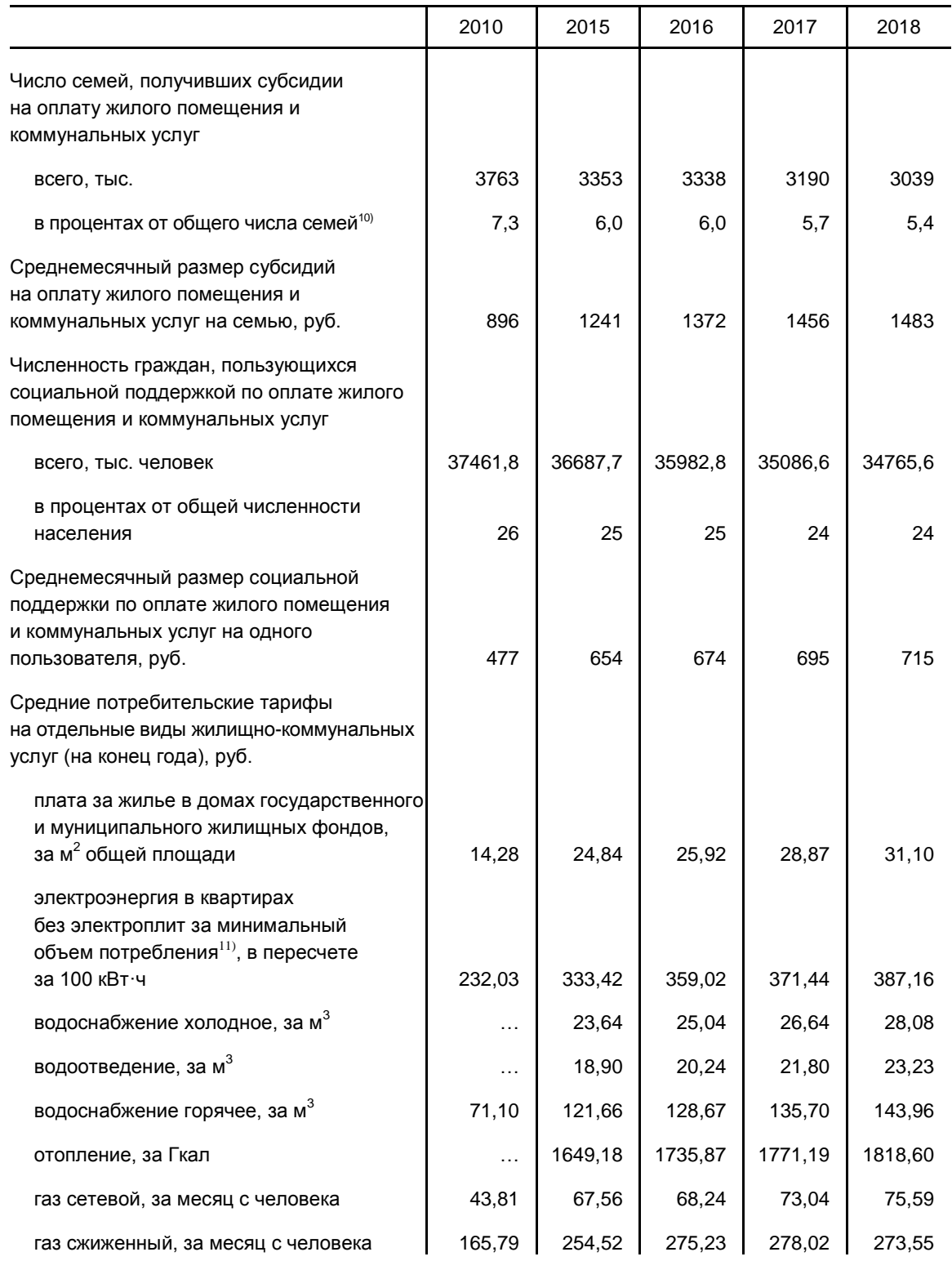


Продолжение табл.1.1

\begin{tabular}{|c|c|c|c|c|c|}
\hline & 2010 & 2015 & 2016 & 2017 & 2018 \\
\hline \multicolumn{6}{|c|}{$\begin{array}{l}\text { Индексы потребительских цен (тарифов) } \\
\text { (декабрь к декабрю предыдущего года), } \\
\text { процентов }\end{array}$} \\
\hline продовольственные товары & 112,9 & 114,0 & 104,6 & 101,1 & 104,7 \\
\hline непродовольственные товары & 105,0 & 113,7 & 106,5 & 102,8 & 104,1 \\
\hline услуги & 108,1 & 110,2 & 104,9 & 104,4 & 103,9 \\
\hline \multicolumn{6}{|l|}{ в том числе: } \\
\hline жилищно-коммунальные услуги & 113,0 & 110,1 & 105,4 & 104,6 & 103,7 \\
\hline жилищные услуги & 107,9 & 112,1 & 105,5 & 104,8 & 103,2 \\
\hline коммунальные услуги & 115,3 & 109,1 & 105,3 & 104,6 & 104,1 \\
\hline
\end{tabular}

1) Данные, начиная с 2011 г. несопоставимы с данными за предыдущие годы в связи с тем, что содержат изменения, связанные с внедрением международной методологии оценки жилищных услуг, производимых и потребляемых собственниками жилья; оценкой потребления основного капитала исходя из его текущей рыночной стоимости; согласованием данных об экспорте и импорте с данными платежного баланса, разработанного по методологии 6 издания «Руководство МВФ по платежному балансу и международной инвестиционной позиции» (РПБ6); включением оценки услуг домашних работников (домашней прислуги).

2) Начиная с 2010 г. данные приведены с учетом Чеченской Республики; с 2015 г. с учетом Республики Крым и г. Севастополя. С 2015 года расчет произведен в соответствии с Методологическими положениями по расчету показателей денежных доходов и расходов населения, утвержденными приказом Росстата от 2.07 .2014 № 465 с изменениями от 20.11.2018.

3) Оценка на основе материалов выборочных обследований домашних хозяйств и макроэкономического показателя среднедушевых денежных доходов населения. Данные за 2010 г. рассчитаны с использованием величины среднедушевого денежного дохода населения, определенной в соответствии с Методикой расчета баланса денежных доходов и расходов населения (постановление Госкомстата России от 16.07.1996 № 61); данные за 2015 - 2018 гг. - в соответствии с Методологическими положениями по расчету показателей денежных доходов и расходов населения (приказ Росстата от 02.07.2014 № 465 с изменениями от 20.11.2018 № 680).

4) За 2015 г. - без учета сведений по Республике Крым и г. Севастополю.

5) Данные рассчитаны в соответствии с актуализированной методикой расчета баланса трудовых ресурсов и оценки затрат труда. 2010 г. - данные пересчитаны с учетом итогов ВПН-2010.

6) По итогам выборочных обследований рабочей силы (по методологии МОТ). До 2017 г. данные по населению в возрасте 15 - 72 лет, с 2017 г. - по населению в возрасте 15 лет и старше.

7) Состоящих на учете в системе Пенсионного фонда Российской Федерации, 2000 г. - в органах социальной защиты населения; данные приведены по состоянию на 1 января года, следующего за отчетным. Снижение численности работающих пенсионеров с 1 января 2016 г. обусловлено вступлением в силу Федерального закона от 29 декабря 2015 г. № 385-Ф3 «О приостановлении действия отдельных положений законодательных актов Российской Федерации, внесении изменений в отдельные законодательные акты Российской Федерации и особенностях увеличения страховой пенсии, фиксированной выплаты к страховой пенсии и социальных пенсий», предусматривающих не индексацию пенсий работающим пенсионерам.

8) В общую численность инвалидов включаются лица, состоящие на учете и получающие пенсию в системе Пенсионного фонда Российской Федерации, Министерстве обороны Российской Федерации, Министерстве внутренних дел Российской Федерации, Федеральной службе безопасности Российской Федерации, Федеральной службе исполнения наказаний Минюста России, начиная с 2017 г. - с учетом лиц, состоящих на учете в системе Следственного комитета Российской Федерации и Генеральной прокуратуры Российской Федерации, начиная с 2018 г. приведены данные из федеральной государственной информационной системы «Федеральный реестр инвалидов»; без учета данных по г. Байконуру.

9) С 2015 г. данные по аварийному жилищному фонду представляет Минстрой России.

10) 2015 - 2018 гг. - показатель рассчитан исходя из ориентировочной оценки числа семей, основанной на данных Всероссийской переписи населения 2010 года о среднем размере частных домохозяйств.

11) 2010 г. - электроэнергия в квартирах без электроплит. 


\section{2. СОСТОЯНИЕ ЖИЛИЩНОГО ФОНДА}

\section{ЖИлИщНЫЙ ФОНД}

\section{1. жилищный ФОНд}

(на конец года; общая площадь жилых помещений; миллионов квадратных метров)

\begin{tabular}{l|r|r|r|r|r}
\hline & 2010 & 2015 & 2016 & 2017 & 2018 \\
\hline Жилищный фонд - всего & $\mathbf{3 2 3 1}$ & $\mathbf{3 5 8 1}$ & $\mathbf{3 6 5 3}$ & $\mathbf{3 7 0 8}$ & $\mathbf{3 7 8 0}$ \\
$\quad$ в том числе: & & & & & \\
государственный & 139 & 116 & 127 & 103 & 106 \\
муниципальный & 321 & 206 & 192 & 182 & 176 \\
частный & 2765 & 3232 & 3306 & 3395 & 3469 \\
$\quad$ из него в собственности граждан & 2657 & 3118 & 3190 & 3286 & 3363 \\
Городской жилищный фонд & $\mathbf{2 3 3 3}$ & $\mathbf{2 6 1 2}$ & $\mathbf{2 6 6 9}$ & $\mathbf{2 7 0 9}$ & $\mathbf{2 7 7 6}$ \\
в том числе: & & & & & \\
государственный & 121 & 105 & 116 & 93 & 96 \\
муниципальный & 256 & 154 & 143 & 134 & 131 \\
частный & 1951 & 2328 & 2384 & 2455 & 2522 \\
из него в собственности граждан & 1872 & 2234 & 2286 & 2364 & 2432 \\
Сельский жилищный фонд & 898 & 970 & 984 & $\mathbf{1 0 0 0}$ & $\mathbf{1 0 0 4}$ \\
$\quad$ в том числе: & & & & & \\
государственный & 17 & 11 & 11 & 10 & 10 \\
муниципальный & 66 & 52 & 49 & 48 & 46 \\
частный & 814 & 904 & 922 & 940 & 947 \\
из него в собственности граждан & 785 & 884 & 903 & 922 & 931 \\
\hline
\end{tabular}

2.2. РАСПРЕДЕЛЕНИЕ ЖИЛИЩНОГО ФОНДА ПО ФОРМАМ СОБСТВЕННОСТИ (на конец года; общая площадь жилых помещений; в процентах)

\begin{tabular}{l|r|r|r|r|r}
\hline & 2010 & 2015 & 2016 & 2017 & 2018 \\
\hline Жилищный фонд, находящийся & & & & & \\
в собственности & & & & & \\
государственной & 4,3 & 3,2 & 3,5 & 2,8 & 2,8 \\
муниципальной & 10,0 & 5,7 & 5,3 & 4,9 & 4,7 \\
частной & 85,6 & 90,2 & 90,5 & 91,5 & 91,8 \\
$\quad$ из нее в собственности граждан & 82,2 & 87,1 & 87,3 & 88,6 & 89,0 \\
\hline
\end{tabular}




\section{3. РАСПРЕДЕЛЕНИЕ ЖИЛИЩНОГО ФОНДА ПО ФОРМАМ СОБСТВЕННОСТИ на КОНец 2018 г.}

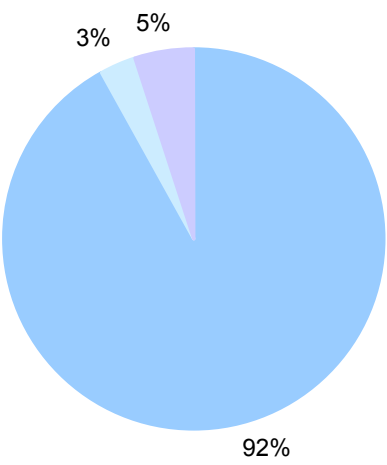

Частный жилищный фонд - 3469,2 млн м²

Государственный жилищный фронд - 106,0 млн м²

Муниципальный жилищный фонд - 176,2 млн м²

2.4. АВАРИЙНЫЙ жИлИщнЫЙ ФОНД'

(на конец года; общая площадь жилых помещений)

\begin{tabular}{l|r|r|r|r|r}
\hline & \multicolumn{1}{|c|}{2010} & \multicolumn{1}{c|}{2015} & 2016 & \multicolumn{1}{c}{2017} & \multicolumn{1}{c}{2018} \\
\hline Аварийный жилищный фонд, тыс. м & 20460,4 & 19625,0 & 22722,9 & 24575,8 & 25473,8 \\
$\begin{array}{l}\text { Удельный вес аварийного жилищного фонда } \\
\text { в общей площади всего жилищного фонда, } \\
\text { процентов }\end{array}$ & 0,6 & 0,5 & 0,6 & 0,7 & 0,7 \\
\hline
\end{tabular}

1) С 2015 г. по данным Минстроя России.

2.5. РАСПРЕДЕЛЕНИЕ ЧИСЛА ЖИЛЫХ ДОМОВ (ИНДИВИДУАЛЬНООПРЕДЕЛЕННЫХ ЗДАНИЙ), ЧИСЛА МНОГОКВАРТИРНЫХ ЖИЛЫХ ДОМОВ И ОБЩЕЙ ПЛОЩАДИ ЖИЛЫХ ПОМЕЩЕНИЙ ПО ГОДАМ ПОСТРОЙКИ В 2018 r.

\begin{tabular}{l|r|r|r|r|r}
\hline & \multicolumn{5}{|c}{ Годы постройки } \\
\cline { 2 - 6 } & \multicolumn{1}{|c|}{ до 1920 } & $1921-1945$ & $1946-1970$ & $1971-1995$ & после 1995 \\
\hline Число жилых домов (индивидуально- & & & & & \\
определенных зданий) & 722317 & 1599084 & 7225682 & 4935506 & 3640801 \\
Число многоквартирных жилых домов & 103572 & 160115 & 958589 & 1217665 & 263805 \\
Общая площадь жилых помещений, тыс. м² & 75160 & 136117 & 965419 & 1434885 & 1121452 \\
\hline
\end{tabular}


2.6. РАСПРЕДЕЛЕНИЕ ЧИСЛА ЖИЛЫХ ДОМОВ (ИНДИВИДУАЛЬНООПРЕДЕЛЕННЫХ ЗДАНИЙ), ЧИСЛА МНОГОКВАРТИРНЫХ ЖИЛЫХ ДОМОВ И ОБЩЕЙ ПЛОЩАДИ ЖИЛЫХ ПОМЕЩЕНИЙ ПО МАТЕРИАЛУ СТЕН В 2018 Г.

\begin{tabular}{|c|c|c|c|c|c|c|c|c|}
\hline & \multicolumn{8}{|c|}{ Материал стен } \\
\hline & камень & кирпич & панели & блоки & дерево & монолит & $\begin{array}{l}\text { смешан- } \\
\text { ный } \\
\text { материал }\end{array}$ & $\begin{array}{c}\text { другие } \\
\text { материаль }\end{array}$ \\
\hline $\begin{array}{l}\text { Число жилых домов } \\
\text { (индивидуально- }\end{array}$ & & & & & & & & \\
\hline $\begin{array}{l}\text { определенных зданий) } \\
\text { Число } \\
\text { многоквартирных }\end{array}$ & 639210 & 4012884 & 212075 & 776084 & 9408380 & 64489 & 1274591 & 1750739 \\
\hline $\begin{array}{l}\text { жилых домов } \\
\text { Общая площадь жилых } \\
\text { помещений, тыс. м² }\end{array}$ & 56504 & 1408686 & 294639 & $\begin{array}{l}148706 \\
246568\end{array}$ & $\begin{array}{l}987344 \\
656114\end{array}$ & 17131 & $\begin{array}{l}124070 \\
161821\end{array}$ & 120648 \\
\hline
\end{tabular}

2.7. РАСПРЕДЕЛЕНИЕ ЧИСЛА ЖИЛЫХ ДОМОВ (ИНДИВИДУАЛЬНООПРЕДЕЛЕННЫХ ЗДАНИЙ), ЧИСЛА МНОГОКВАРТИРНЫХ ЖИЛЫХ ДОМОВ И ОБЩЕЙ ПЛОЩАДИ ЖИЛЫХ ПОМЕЩЕНИЙ ПО ПРОЦЕНТУ ИЗНОСА В 2018 Г.

\begin{tabular}{l|c|c|c|c}
\hline & \multicolumn{3}{|c}{ Процент износа } \\
\cline { 2 - 5 } & от 0 до 30 & от 31 до 65 & от 66 до 70 & свыше 70 \\
\hline \multirow{2}{*}{$\begin{array}{l}\text { Число жилых домов (индивидуально- } \\
\text { определенных зданий) }\end{array}$} & & & & \\
Число многоквартирных жилых домов & 942433 & 1360766 & 231371 & 101065 \\
Общая площадь жилых помещений, & & 8624410 & 1445856 & 516610 \\
тыс. м & & & & \\
\hline
\end{tabular}




\section{3. ЖИЛИЩНЫЕ УСЛОВИЯ НАСЕЛЕНИЯ}

\section{ОБЕСПЕЧЕННОСТЬ НАСЕЛЕНИЯ ЖИЛЬЕМ}

3.1. ЧИСЛЕННОСТЬ НАСЕЛЕНИЯ РОССИЙСКОЙ ФЕДЕРАЦИИ

(на конец года)

\begin{tabular}{c|c|c|c|c|c}
\hline \multirow{2}{*}{ Годы } & $\begin{array}{c}\text { Все население, } \\
\text { млн человек }\end{array}$ & \multicolumn{2}{|c|}{ в том числе } & \multicolumn{2}{|c}{$\begin{array}{c}\text { В общей численности населения, } \\
\text { процентов }\end{array}$} \\
\cline { 3 - 6 } & & $\begin{array}{c}\text { городское } \\
\text { население }\end{array}$ & $\begin{array}{c}\text { сельское } \\
\text { население }\end{array}$ & $\begin{array}{c}\text { городское } \\
\text { население }\end{array}$ & $\begin{array}{c}\text { сельское } \\
\text { население }\end{array}$ \\
\hline 2010 & 142,9 & 105,4 & 37,5 & 74 & 26 \\
2015 & 146,5 & 108,6 & 37,9 & 74 & 26 \\
2016 & 146,8 & 109,0 & 37,8 & 74 & 26 \\
2017 & 146,9 & 109,3 & 37,6 & 74 & 26 \\
2018 & 146,8 & 109,5 & 37,3 & 75 & 25 \\
\hline
\end{tabular}

\section{2. ОБЩАЯ ПЛОЩАДЬ ЖИЛЫХ ПОМЕЩЕНИЙ, ПРИХОДЯЩАЯСЯ В СРЕДНЕМ НА ОДНОГО ЖИТЕЛЯ}

(квадратных метров)

\begin{tabular}{l|r|r|r|r|r}
\hline & 2010 & 2015 & 2016 & 2017 & 2018 \\
\hline Общая площадь жилых помещений, & & & & & \\
приходящаяся в среднем на одного & & & & & \\
жителя - всего & 22,6 & 24,4 & 24,9 & 25,2 & 25,8 \\
в городской местности & 22,1 & 24,0 & 24,5 & 24,8 & 25,4 \\
в сельской местности & 24,0 & 25,6 & 26,1 & 26,6 & 26,9 \\
\hline
\end{tabular}

\section{3. ПРЕДОСТАВЛЕНИЕ ГРАЖДАНАМ ЖИЛЫХ ПОМЕЩЕНИЙ}

\begin{tabular}{|c|c|c|c|c|c|}
\hline & 2010 & 2015 & 2016 & 2017 & 2018 \\
\hline $\begin{array}{l}\text { Число семей, состоявших на учете } \\
\text { в качестве нуждающихся в жилых } \\
\text { помещениях (на конец года), тыс. } \\
\text { в процентах от числа всех семей } \\
\text { Число семей, получивших жилые } \\
\text { помещения и улучшивших жилищные } \\
\text { условия за год, тыс. } \\
\text { в процентах от числа семей, состоявших } \\
\text { на учете в качестве нуждающихся } \\
\text { в жилых помещениях }\end{array}$ & $\begin{array}{r}2821 \\
6\end{array}$ & $\begin{array}{r}2612 \\
5\end{array}$ & $\begin{array}{r}2542 \\
5\end{array}$ & $\begin{array}{r}2458 \\
4\end{array}$ & $\begin{array}{r}2364 \\
4\end{array}$ \\
\hline
\end{tabular}


3.4. ХАРАКТЕРИСТИКА ЖИЛЫХ КВАРТИР ПО ЧИСЛУ КОМНАТ

\begin{tabular}{l|r|r|r|r|r}
\hline & 2010 & \multicolumn{1}{|c|}{2015} & \multicolumn{1}{c|}{2016} & \multicolumn{1}{c|}{2017} & \multicolumn{1}{c}{2018} \\
\hline Число квартир - всего, млн & 60,1 & 64,0 & 64,9 & 65,9 & 66,9 \\
$\quad$ в том числе: & & & & & \\
однокомнатных & 14,1 & 15,4 & 15,8 & 16,2 & 16,6 \\
двухкомнатных & 23,9 & 24,9 & 25,2 & 25,5 & 25,7 \\
трехкомнатных & 17,4 & 18,2 & 18,4 & 18,6 & 18,7 \\
четырехкомнатных и более & 4,7 & 5,2 & 5,3 & 5,3 & 5,4 \\
Общая площадь квартир - всего, млн м & 3182 & 3494 & 3566 & 3647 & 3723 \\
в том числе: & & & & & \\
однокомнатных & 472 & 538 & 557 & 579 & 594 \\
двухкомнатных & 1128 & 1206 & 1226 & 1247 & 1260 \\
трехкомнатных & 1107 & 1189 & 1209 & 1230 & 1244 \\
четырехкомнатных и более & 479 & 540 & 545 & 571 & 586 \\
Средний размер одной квартиры, & & & & & \\
м общей площади жилых помещений & 52,9 & 54,6 & 54,9 & 55,3 & 55,7 \\
однокомнатной & 33,4 & 35,0 & 35,2 & 35,7 & 35,8 \\
двухкомнатной & 47,2 & 48,3 & 48,6 & 48,9 & 49,1 \\
трехкомнатной & 63,4 & 65,2 & 65,6 & 66,1 & 66,4 \\
четырехкомнатной и более & 102,0 & 104,5 & 105,6 & 106,9 & 107,9 \\
\hline
\end{tabular}

\section{БЛАГОУСТРОЙСТВО ЖИЛИЩНОГО ФОНДА}

\section{5. БЛАГОУСТРОЙСТВО ЖИЛИЩНОГО ФОНДА}

(на конец года; в процентах)

\begin{tabular}{|c|c|c|c|c|c|c|c|}
\hline & \multicolumn{7}{|c|}{ Удельный вес общей площади, оборудованной } \\
\hline & $\begin{array}{c}\text { водопро- } \\
\text { водом }\end{array}$ & $\begin{array}{c}\text { водоотве- } \\
\text { дением } \\
\text { (канализа- } \\
\text { цией) }\end{array}$ & $\begin{array}{l}\text { отопле- } \\
\text { нием }\end{array}$ & $\begin{array}{c}\text { ваннами } \\
\text { (душем) }\end{array}$ & $\begin{array}{c}\text { газом } \\
\text { (сетевым, } \\
\text { сжижен- } \\
\text { ным) }\end{array}$ & $\begin{array}{c}\text { горячим } \\
\text { водо- } \\
\text { снабже- } \\
\text { нием }\end{array}$ & $\begin{array}{c}\text { напольны- } \\
\text { ми электри- } \\
\text { ческими } \\
\text { плитами }\end{array}$ \\
\hline \multicolumn{8}{|l|}{ Жилищный фонд } \\
\hline 2010 & 78 & 74 & 83 & 67 & 69 & 65 & 19 \\
\hline 2015 & 81 & 77 & 85 & 69 & 67 & 68 & 22 \\
\hline 2016 & 82 & 77 & 86 & 70 & 66 & 69 & 23 \\
\hline 2017 & 82 & 78 & 86 & 70 & 67 & 69 & 23 \\
\hline 2018 & 83 & 78 & 86 & 71 & 66 & 70 & 23 \\
\hline \multicolumn{8}{|c|}{ Городской жилищный фонд } \\
\hline 2010 & 89 & 87 & 92 & 81 & 67 & 80 & 25 \\
\hline 2015 & 91 & 89 & 92 & 82 & 64 & 81 & 27 \\
\hline 2016 & 91 & 89 & 92 & 82 & 64 & 82 & 29 \\
\hline 2017 & 91 & 89 & 93 & 82 & 64 & 82 & 29 \\
\hline 2018 & 91 & 89 & 93 & 82 & 64 & 82 & 29 \\
\hline \multicolumn{8}{|c|}{ Сельский жилищный фонд } \\
\hline 2010 & 48 & 39 & 60 & 29 & 75 & 25 & 4 \\
\hline 2015 & 57 & 45 & 67 & 34 & 74 & 33 & 6 \\
\hline 2016 & 58 & 47 & 68 & 35 & 74 & 34 & 6 \\
\hline 2017 & 59 & 48 & 68 & 36 & 73 & 35 & 7 \\
\hline 2018 & 61 & 50 & 69 & 38 & 74 & 38 & 7 \\
\hline
\end{tabular}




\section{6. УДЕЛЬНЫЙ ВЕС ОБЩЕЙ ПЛОЩАДИ ЖИЛЫХ ПОМЕЩЕНИЙ, ОБОРУДОВАННОЙ ОДНОВРЕМЕННО ВОДОПРОВОДОМ, ВОДООТВЕДЕНИЕМ (КАНАЛИЗАЦИЕЙ), ОТОПЛЕНИЕМ, ГОРЯЧИМ ВОДОСНАБЖЕНИЕМ, ГАЗОМ ИЛИ НАПОЛЬНЫМИ ЭЛЕКТРОПЛИТАМИ} (в процентах)

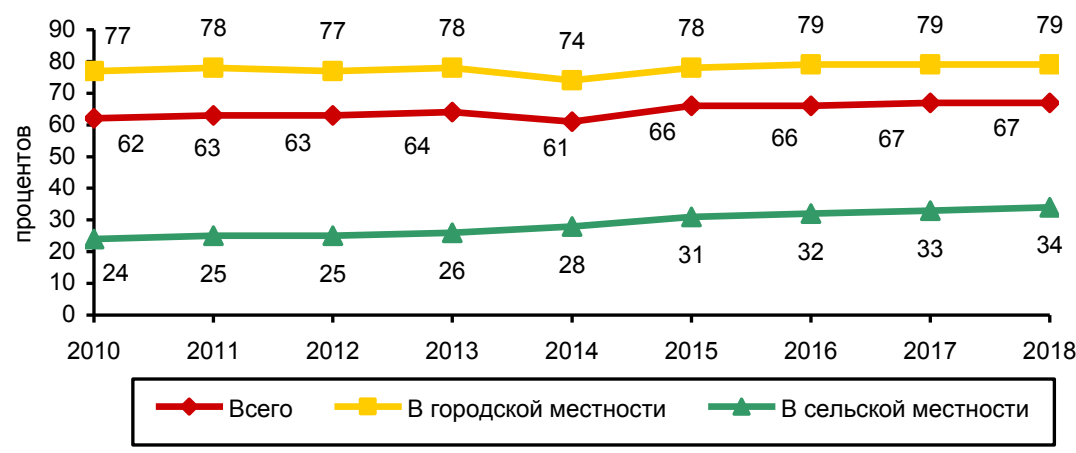

СОСТОЯНИЕ ИНФРАСТРУКТУРЫ ЖИЛИЩНОГО ХОЗЯЙСТВА

3.7. ВОДОСНАБЖЕНИЕ НАСЕЛЕННЫХ ПУНКТОВ

\begin{tabular}{l|r|r|r|r|r}
\hline & 2010 & 2015 & 2016 & 2017 & 2018 \\
\hline Число централизованных систем & & & & & \\
водоснабжения, единиц & 51962 & 53223 & 52852 & 53098 & 53561 \\
$\quad$ в том числе: & & & & & \\
в городской местности & 6907 & 7169 & 7582 & 7666 & 7872 \\
$\quad$ в сельской местности & 45055 & 46054 & 45270 & 45432 & 45689 \\
Одиночное протяжение уличной & & & & & \\
водопроводной сети (на конец года), & 344,9 & 372,2 & 374,1 & 378,1 & 379,0 \\
тыс. км & & & & & \\
$\quad$ в том числе: & 145,9 & 152,9 & 155,4 & 157,1 & 158,3 \\
в городской местности & 198,9 & 219,3 & 218,7 & 221,1 & 220,7 \\
в сельской местности & & & & & \\
Установленная производственная & 89,5 & 92,2 & 89,5 & 90,7 & 91,2 \\
мощность водопроводов, млн м ${ }^{3}$ в сутки & & & & & \\
в том числе: & 72,1 & 70,7 & 70,6 & 71,3 & 71,8 \\
в городской местности & 17,4 & 21,5 & 19,0 & 19,4 & 19,4 \\
в сельской местности & & & & & \\
Уличная водопроводная сеть, & 147,7 & 165,5 & 168,2 & 169,5 & 169,9 \\
нуждающаяся в замене, тыс. км & 65,6 & 72,7 & 74,2 & 73,9 & 74,7 \\
в городской местности & 82,1 & 92,8 & 94,0 & 95,6 & 95,3 \\
в сельской местности & 42,8 & 44,5 & 45,0 & 44,8 & 44,8 \\
в процентах ко всему протяжению & 170,0 & 84,8 & 74,4 & 64,4 & 65,7 \\
Число аварий водопровода, тыс. & 84,0 & 43,3 & 38,8 & 33,6 & 34,9 \\
в городской местности & 86,0 & 41,5 & 35,6 & 30,8 & 30,8 \\
в сельской местности & & &
\end{tabular}




\section{8. СРЕДНЕСУТОЧНЫЙ ОТПУСК ВОДЫ В РАСЧЕТЕ НА ОДНОГО ЖИТЕЛЯ}

(литров)

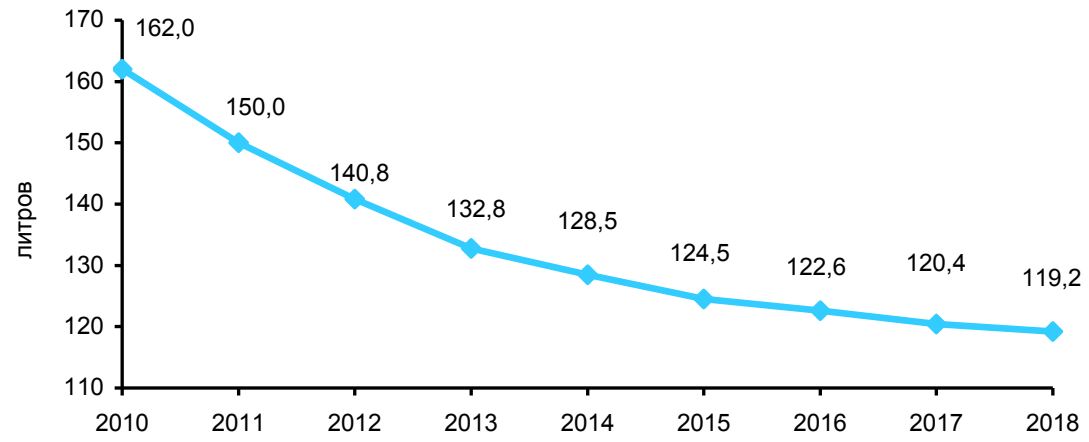

3.9. КАНАЛИЗАЦИЯ НАСЕЛЕННЫХ ПУНКТОВ

\begin{tabular}{|c|c|c|c|c|c|}
\hline & 2010 & 2015 & 2016 & 2017 & 2018 \\
\hline $\begin{array}{l}\text { Число централизованных систем } \\
\text { водоотведения (канализации) }\end{array}$ & 7906 & 7759 & 7804 & 7784 & 7789 \\
\hline в том числе: & & & & & \\
\hline в городской местности & 3075 & 2949 & 2978 & 3054 & 3160 \\
\hline в сельской местности & 4831 & 4810 & 4826 & 4730 & 4629 \\
\hline $\begin{array}{l}\text { Одиночное протяжение уличной } \\
\text { канализационной сети (на конец года) }\end{array}$ & & & & & \\
\hline $\begin{array}{l}\text { тыс. км } \\
\text { в том числе: }\end{array}$ & 76,5 & 81,0 & 81,7 & 82,8 & 83,6 \\
\hline в городской местности & 61,1 & 63,9 & 64,3 & 65,2 & 66,3 \\
\hline в сельской местности & 15,4 & 17,1 & 17,4 & 17,5 & 17,3 \\
\hline $\begin{array}{l}\text { Использование мощности очистных } \\
\text { сооружений канализации - всего, } \\
\text { процентов }\end{array}$ & 53,6 & 46,3 & 46,7 & 46,4 & 45,0 \\
\hline в городской местности & 55,4 & 47,8 & 48,4 & 48,1 & 46,6 \\
\hline в сельской местности & 23,7 & 20,9 & 19,8 & 20,5 & 19,3 \\
\hline $\begin{array}{l}\text { Установленная пропускная способность } \\
\text { очистных сооружений - всего, } \\
\text { тыс. м³ в сутки }\end{array}$ & 57922,2 & 56176,0 & 56035,4 & 55874,4 & 56017,7 \\
\hline В городской местности & 54574,9 & 53076,4 & 52792,6 & 52479,9 & 52737,0 \\
\hline в сельской местности & 3347,3 & 3099,6 & 3242,8 & 3394,4 & 3280,7 \\
\hline $\begin{array}{l}\text { Уличная канализационная сеть, } \\
\text { нуждающаяся в замене, тыс. км }\end{array}$ & 28,6 & 35,3 & 36,8 & 37,0 & 37,1 \\
\hline в городской местности & 23,9 & 29,3 & 30,3 & 30,6 & 30,9 \\
\hline в сельской местности & 4,7 & 6,0 & 6,5 & 6,4 & 6,3 \\
\hline в процентах ко всему протяжению & 37,4 & 43,6 & 45,0 & 44,7 & 44,4 \\
\hline Число аварий канализации, тыс. & 39,2 & 37,2 & 31,3 & 31,8 & 25,4 \\
\hline в городской местности & 32,9 & 23,4 & 17,3 & 19,1 & 13,7 \\
\hline в сельской местности & 6,3 & 13,8 & 14,0 & 12,6 & 11,7 \\
\hline
\end{tabular}


3.10. ТЕПЛОСНАБЖЕНИЕ НАСЕЛЕННЫХ ПУНКТОВ

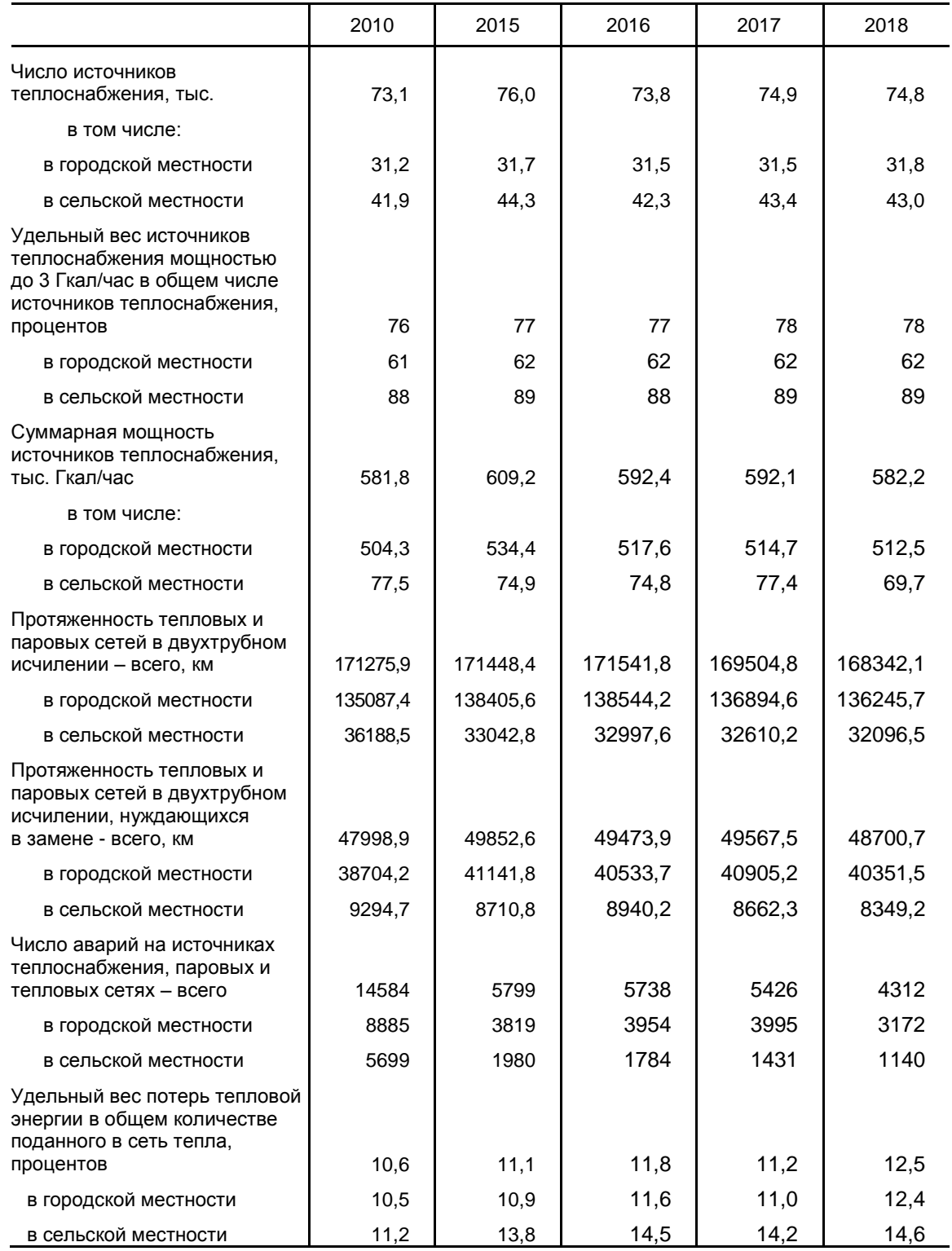




\subsection{1. НАЛИЧИЕ И СОСТОЯНИЕ ОСНОВНЫХ ФОНДОВ ОРГАНИЗАЦИЙ ВИДОВ ЭКОНОМИЧЕСКОЙ ДЕЯТЕЛЬНОСТИ, ОТНОСЯЩИХСЯ К ЖИЛИЩНО-КОММУНАЛЬНОМУ ХОЗЯЙСТВУ в 2010 - 2016 гг. 1); 2)}

\begin{tabular}{|c|c|c|c|}
\hline & 2010 & 2015 & 2016 \\
\hline $\begin{array}{l}\text { Наличие основных фондов (на конец года; } \\
\text { по полной учетной стоимости) - всего, млрд руб. } \\
\text { в том числе: }\end{array}$ & 2267,0 & 3679,9 & 3904,2 \\
\hline распределения электроэнергии и торговли электроэнергией & 279,5 & 705,1 & 684,7 \\
\hline управления эксплуатацией жилого фонда & 108,0 & 107,6 & 104,9 \\
\hline производства и распределения газообразного топлива & 215,1 & 426,4 & 460,2 \\
\hline $\begin{array}{l}\text { производства, передачи и распределения пара и горячей } \\
\text { воды (тепловой энергии) }\end{array}$ & 718,9 & 1032,8 & 1120,9 \\
\hline сбора, очистки и распределения воды & 685,9 & 1037,5 & 1128,0 \\
\hline управления эксплуатацией нежилого фронда & 39,9 & 116,9 & 127,7 \\
\hline сбора сточных вод, отходов и аналогичной деятельности & 191,8 & 232,5 & 253,8 \\
\hline предоставления персональных услуг & 27,9 & 21,1 & 24,0 \\
\hline $\begin{array}{l}\text { Степень износа основных фондов (на конец года), } \\
\text { процентов }\end{array}$ & 47,9 & 40,2 & 42,4 \\
\hline распределения электроэнергии и торговли электроэнергией & 42,9 & 39,5 & 42,6 \\
\hline управления эксплуатацией жилого фонда & 41,3 & 34,1 & 38,5 \\
\hline производства и распределения газообразного топлива & 44,8 & 33,8 & 39,5 \\
\hline $\begin{array}{l}\text { производства, передачи и распределения пара и горячей } \\
\text { воды (тепловой энергии) }\end{array}$ & 49,2 & 45,0 & 46,1 \\
\hline сбора, очистки и распределения воды & 52,6 & 42,2 & 42,0 \\
\hline управления эксплуатацией нежилого фонда & 46,1 & 22,5 & 23,7 \\
\hline сбора сточных вод, отходов и аналогичной деятельности & 42,8 & 34,8 & 43,4 \\
\hline предоставления персональных услуг & 34,9 & 40,6 & 42,5 \\
\hline $\begin{array}{l}\text { Коэффициент обновления (ввод в действие основных } \\
\text { фондов в процентах от наличия основных фондов } \\
\text { на конец года; по полной учетной стоимости) }\end{array}$ & 7,7 & 7,0 & 7,5 \\
\hline распределения электроэнергии и торговли электроэнергией & 9,7 & 8,9 & 12,4 \\
\hline управления эксплуатацией жилого фонда & 8,0 & 2,7 & 2,7 \\
\hline производства и распределения газообразного топлива & 8,5 & 6,9 & 7,8 \\
\hline $\begin{array}{l}\text { производства, передачи и распределения пара и горячей } \\
\text { воды (тепловой энергии) }\end{array}$ & 6,7 & 6,3 & 7,1 \\
\hline сбора, очистки и распределения воды & 7,2 & 5,8 & 4,9 \\
\hline управления эксплуатацией нежилого фронда & 3,4 & 9,4 & 14,5 \\
\hline сбора сточных вод, отходов и аналогичной деятельности & 9,2 & 10,9 & 6,0 \\
\hline предоставления персональных услуг & 12,1 & 6,7 & 6,2 \\
\hline
\end{tabular}


Продолжение табл. 3.11

\begin{tabular}{|c|c|c|c|}
\hline & 2010 & 2015 & 2016 \\
\hline $\begin{array}{l}\text { Коэффициент выбытия (ликвидация основных фондов, } \\
\text { в процентах от наличия основных фондов на начало года; } \\
\text { по полной учетной стоимости): }\end{array}$ & 0,4 & 0,4 & 0,8 \\
\hline распределения электроэнергии и торговли электроэнергией & 0,5 & 0,4 & 2,5 \\
\hline управления эксплуатацией жилого фонда & 1,0 & 0,5 & 0,7 \\
\hline производства и распределения газообразного топлива & 0,5 & 0,4 & 0,3 \\
\hline $\begin{array}{l}\text { производства, передачи и распределения пара и горячей } \\
\text { воды (тепловой энергии) }\end{array}$ & 0,5 & 0,6 & 0,6 \\
\hline сбора, очистки и распределения воды & 0,2 & 0,2 & 0,3 \\
\hline управления эксплуатацией нежилого фонда & 0,7 & 0,3 & 0,5 \\
\hline сбора сточных вод, отходов и аналогичной деятельности & 0,3 & 0,5 & 0,3 \\
\hline предоставления персональных услуг & 0,7 & 0,5 & 0,4 \\
\hline $\begin{array}{l}\text { Удельный вес полностью изношенных основных фондов, } \\
\text { процентов }\end{array}$ & 18,8 & 13,0 & 14,0 \\
\hline распределения электроэнергии и торговли электроэнергией & 15,0 & 10,2 & 10,2 \\
\hline управления эксплуатацией жилого фонда & 6,5 & 7,3 & 8,7 \\
\hline производства и распределения газообразного топлива & 12,7 & 8,0 & 9,3 \\
\hline $\begin{array}{l}\text { производства, передачи и распределения пара и горячей } \\
\text { воды (тепловой энергии) }\end{array}$ & 23,0 & 12,9 & 15,3 \\
\hline сбора, очистки и распределения воды & 24,2 & 19,6 & 19,1 \\
\hline управления эксплуатацией нежилого фонда & 18,3 & 4,4 & 5,7 \\
\hline сбора сточных вод, отходов и аналогичной деятельности & 5,4 & 8,5 & 11,1 \\
\hline предоставления персональных услуг & 4,7 & 8,8 & 11,8 \\
\hline
\end{tabular}

1) По коммерческим организациям (без субъектов малого предпринимательства).

2) В соответствии с Общероссийским классификатором видов экономической деятельности (ОКВЭД-2007) ОК 029-2007. 


\subsection{2. ВИДОВАЯ СТРУКТУРА ОСНОВНЫХ ФОНДОВ ОРГАНИЗАЦИЙ ВИДОВ ЭКОНОМИЧЕСКОЙ ДЕЯТЕЛЬНОСТИ, ОТНОСЯЩИХСЯ К ЖИЛИЩНО-КОММУНАЛЬНОМУ ХОЗЯЙСТВУ в 2010 - 2016 гг. 1); 2)} (на конец года; в процентах к итогу)

\begin{tabular}{|c|c|c|c|}
\hline & 2010 & 2015 & 2016 \\
\hline $\begin{array}{l}\text { Все основные фонды } \\
\text { из них: }\end{array}$ & 100 & 100 & 100 \\
\hline здания & 16,1 & 15,4 & 15,5 \\
\hline сооружения & 61,8 & 62,9 & 61,5 \\
\hline машины и оборудование & 15,3 & 18,2 & 18,2 \\
\hline $\begin{array}{l}\text { транспортные средства } \\
\text { из них по организациям: }\end{array}$ & 4,7 & 2,3 & 2,4 \\
\hline $\begin{array}{l}\text { распределения электроэнергии и торговля } \\
\text { электроэнергией }\end{array}$ & 100 & 100 & 100 \\
\hline \multicolumn{4}{|l|}{ из них: } \\
\hline здания & 13,8 & 10,3 & 11,1 \\
\hline сооружения & 49,1 & 54,7 & 47,2 \\
\hline машины и оборудование & 29,9 & 32,3 & 31,9 \\
\hline транспортные средства & 1,7 & 1,3 & 1,3 \\
\hline $\begin{array}{l}\text { управления эксплуатацией жилого фонда } \\
\text { из них: }\end{array}$ & 100 & 100 & 100 \\
\hline здания & 64,2 & 56,6 & 53,2 \\
\hline сооружения & 18,8 & 28,7 & 30,8 \\
\hline машины и оборудование & 8,9 & 8,2 & 9,4 \\
\hline транспортные средства & 5,0 & 5,1 & 5,1 \\
\hline $\begin{array}{l}\text { производства и распределения газообразного } \\
\text { топлива }\end{array}$ & 100 & 100 & 100 \\
\hline \multicolumn{4}{|l|}{ из них: } \\
\hline здания & 8,9 & 7,9 & 7,8 \\
\hline сооружения & 78,2 & 79,5 & 79,3 \\
\hline машины и оборудование & 8,4 & 8,4 & 8,8 \\
\hline транспортные средства & 3,2 & 3,3 & 3,3 \\
\hline $\begin{array}{l}\text { производства, передачи и распределения пара } \\
\text { и горячей воды (тепловой энергии) }\end{array}$ & 100 & 100 & 100 \\
\hline \multicolumn{4}{|l|}{ из них: } \\
\hline здания & 15,8 & 16,2 & 16,7 \\
\hline сооружения & 61,1 & 57,2 & 56,1 \\
\hline машины и оборудование & 19,9 & 24,0 & 24,4 \\
\hline транспортные средства & 1,3 & 1,6 & 1,5 \\
\hline
\end{tabular}


Продолжение табл. 3.12

\begin{tabular}{|c|c|c|c|}
\hline & 2010 & 2015 & 2016 \\
\hline сбора, очистки и распределения воды & 100 & 100 & 100 \\
\hline \multicolumn{4}{|l|}{ из них: } \\
\hline здания & 10,0 & 10,0 & 10,2 \\
\hline сооружения & 79,8 & 79,1 & 78,9 \\
\hline машины и оборудование & 8,0 & 9,3 & 9,3 \\
\hline транспортные средства & 1,1 & 1,0 & 1,0 \\
\hline управления эксплуатацией нежилого фонда & 100 & 100 & 100 \\
\hline \multicolumn{4}{|l|}{ из них: } \\
\hline здания & 46,9 & 74,8 & 69,3 \\
\hline сооружения & 36,1 & 10,3 & 13,7 \\
\hline машины и оборудование & 9,7 & 8,4 & 10,4 \\
\hline транспортные средства & 2,6 & 2,8 & 2,6 \\
\hline $\begin{array}{l}\text { сбора сточных вод, отходов } \\
\text { и аналогичной деятельности }\end{array}$ & 100 & 100 & 100 \\
\hline \multicolumn{4}{|l|}{ из них: } \\
\hline здания & 11,1 & 14,2 & 14,7 \\
\hline сооружения & 36,0 & 56,0 & 55,1 \\
\hline машины и оборудование & 15,0 & 17,1 & 17,0 \\
\hline транспортные средства & 36,2 & 11,2 & 11,7 \\
\hline предоставления персональных услуг & 100 & 100 & 100 \\
\hline \multicolumn{4}{|l|}{ из них: } \\
\hline здания & 53,8 & 44,3 & 42,0 \\
\hline сооружения & 16,1 & 16,9 & 12,4 \\
\hline машины и оборудование & 18,7 & 22,7 & 21,3 \\
\hline транспортные средства & 5,3 & 7,7 & 7,0 \\
\hline
\end{tabular}

1) По коммерческим организациям (без субъектов малого предпринимательства).

2) В соответствии с Общероссийским классификатором видов экономической деятельности (ОКВЭД-2007) ОК 029-2007. 


\subsection{3. НАЛИЧИЕ И СОСТОЯНИЕ ОСНОВНЫХ ФОНДОВ ОРГАНИЗАЦИЙ ВИДОВ ЭКОНОМИЧЕСКОЙ ДЕЯТЕЛЬНОСТИ, ОТНОСЯЩИХСЯ К ЖИЛИЩНО-КОММУНАЛЬНОМУ ХОЗЯЙСТВУ');2)}

Наличие основных фондов (на конец года;
по полной учетной стоиости) - всего, млрд руб.
в том числе:
распределения электроэнергии
управления эксплуатацией жилого фонда за вознаграждение
или на договорной основе
производства и распределения газообразного топлива
производства, передачи и распределения пара и горячей воды;
кондиционирования воздуха
забора, очистки и распределения воды
управления эксплуатацией нежилого фонда за вознаграждение
или на договорной основе
сбора и обработки сточных вод
деятельности по предоставлению прочих персональных услуг

Степень износа основных фондов (на конец года), процентов

в том числе:

распределения электроэнергии

управления эксплуатацией жилого фонда за вознаграждение или на договорной основе

производства и распределения газообразного топлива

производства, передачи и распределения пара и горячей воды; кондиционирования воздуха

забора, очистки и распределения воды

управления эксплуатацией нежилого фонда за вознаграждение или на договорной основе

сбора и обработки сточных вод

деятельности по предоставлению прочих персональных услуг

Коэффициент обновления (ввод в действие основных фондов в процентах от наличия основных фондов на конец года; по полной учетной стоимости)

в том числе:

распределения электроэнергии

управления эксплуатацией жилого фонда за вознаграждение или на договорной основе

производства и распределения газообразного топлива

производства, передачи и распределения пара и горячей воды; кондиционирования воздуха

забора, очистки и распределения воды

управления эксплуатацией нежилого фонда за вознаграждение или на договорной основе

сбора и обработки сточных вод

деятельности по предоставлению прочих персональных услуг

\begin{tabular}{|c|c|}
\hline 2017 & 2018 \\
\hline 3923,0 & 4175,5 \\
\hline 506,9 & 548,1 \\
\hline 80,5 & 80,5 \\
\hline 538,3 & 595,6 \\
\hline 1242,1 & 1312,1 \\
\hline 1206,1 & 1276,2 \\
\hline 152,1 & 137,1 \\
\hline 166,0 & 187,5 \\
\hline 31,0 & 38,4 \\
\hline 42,8 & 43,0 \\
\hline 48,2 & 50,9 \\
\hline 41,3 & 43,1 \\
\hline 37,9 & 33,3 \\
\hline 47,4 & 48,0 \\
\hline 42,1 & 42,9 \\
\hline 26,5 & 27,8 \\
\hline 27,8 & 27,8 \\
\hline 44,5 & 42,2 \\
\hline 7,1 & 8,2 \\
\hline 6,4 & 11,5 \\
\hline 3,6 & 6,5 \\
\hline 7,1 & 11,6 \\
\hline 7,8 & 7,9 \\
\hline 5,9 & 5,9 \\
\hline 16,8 & 7,6 \\
\hline 6,3 & 6,3 \\
\hline 5,6 & 15,6 \\
\hline
\end{tabular}


Продолжение табл. 3.13

Коэффициент выбытия (ликвидация основных фондов, в процентах от наличия основных фондов на начало года; по полной учетной стоимости):

в том числе:

распределения электроэнергии

управления эксплуатацией жилого фонда за вознаграждение или на договорной основе

производства и распределения газообразного топлива

производства, передачи и распределения пара и горячей воды; кондиционирования воздуха

забора, очистки и распределения воды

управления эксплуатацией нежилого фонда за вознаграждение или на договорной основе

сбора и обработки сточных вод

деятельности по предоставлению прочих персональных услуг

Удельный вес полностью изношенных основных фондов, процентов

в том числе:

распределения электроэнергии

управления эксплуатацией жилого фонда за вознаграждение или на договорной основе

производства и распределения газообразного топлива

производства, передачи и распределения пара и горячей воды; кондиционирования воздуха

забора, очистки и распределения воды

управления эксплуатацией нежилого фонда за вознаграждение или на договорной основе

сбора и обработки сточных вод

деятельности по предоставлению прочих персональных услуг

\begin{tabular}{|c|c|}
\hline 2017 & 2018 \\
\hline 0,3 & 0,4 \\
\hline 0,4 & 0,6 \\
\hline 1,5 & 0,8 \\
\hline 0,3 & 0,3 \\
\hline 0,5 & 0,6 \\
\hline 0,2 & 0,2 \\
\hline 0,1 & 0,7 \\
\hline 0,2 & 1,0 \\
\hline 0,6 & 0,3 \\
\hline 15,3 & 14,1 \\
\hline 15,2 & 17,3 \\
\hline 13,4 & 13,7 \\
\hline 10,8 & 10,2 \\
\hline 16,5 & 12,1 \\
\hline 18,8 & 18,8 \\
\hline 5,5 & 4,9 \\
\hline 6,8 & 6,6 \\
\hline 11,6 & 7,5 \\
\hline
\end{tabular}

1) По коммерческим организациям (без субъектов малого предпринимательства).

2) В соответствии с Общероссийским классификатором видов экономической деятельности (ОКВЭД-2) ОК 029-2014. 


\subsection{4. СТРУКТУРА НАЛИЧИЯ ОСНОВНЫХ ФОНДОВ КОММЕРЧЕСКИХ ОРГАНИЗАЦИЙ (БЕЗ УЧЕТА СУБЪЕКТОВ МАЛОГО ПРЕДПРИНИМАТЕЛЬСТВА) ЖИЛИЩНО-КОММУНАЛЬНОГО ХОЗЯЙСТВА РОССИЙСКОЙ ФЕДЕРАЦИИ ПО ВИДАМ ЭКОНОМИЧЕСКОЙ ДЕЯТЕЛЬНОСТИ На конец 2018 г.} (в процентах)

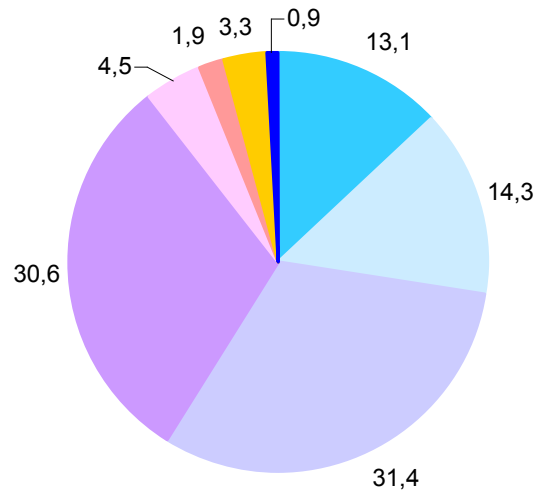

Распределение электроэнергии

Производство и распределение газообразного топлива

Производство, передача и распределение пара и горячей воды; кондиционирование воздуха Забор, очистка и распределение воды

Сбор и обработка сточных вод

Управление эксплуатацией жилого фонда за вознаграждние или на договорной основе Управление эксплуатацией нежилого фонда за вознаграждние или на договорной основе

口Деятельность по предоставлению прочих персональных услуг

\subsection{5. ВИДОВАЯ СТРУКТУРА ОСНОВНЫХ ФОНДОВ ОРГАНИЗАЦИЙ ВИДОВ ЭКОНОМИЧЕСКОЙ ДЕЯТЕЛЬНОСТИ, ОТНОСЯЩИХСЯ К ЖИЛИЩНО-КОММУНАЛЬНОМУ ХОЗЯЙСТВУ ${ }^{1) ; 2)}$}

(на конец года; в процентах к итогу)

\begin{tabular}{l|rr}
\hline & 2017 & 2018 \\
\hline Bсе основные фонды & $\mathbf{1 0 0}$ & $\mathbf{1 0 0}$ \\
из них: & 15,4 & 14,6 \\
здания & 63,8 & 64,3 \\
сооружения & 16,4 \\
машины и оборудование & 1,8 & 16,9 \\
транспортные средства & 1,8 \\
из них по организациям: & $\mathbf{1 0 0}$ \\
распределения электроэнергии & 100 \\
из них: & 10,3 \\
здания & 46,2 & 10,2 \\
сооружения & 43,9
\end{tabular}


Продолжение табл. 3.15

\begin{tabular}{|c|c|c|}
\hline & 2017 & 2018 \\
\hline машины и оборудование & 28,4 & 29,2 \\
\hline транспортные средства & 1,4 & 1,4 \\
\hline $\begin{array}{l}\text { управления эксплуатацией жилого фонда } \\
\text { за вознаграждение или на договорной основе }\end{array}$ & 100 & 100 \\
\hline \multicolumn{3}{|l|}{ из них: } \\
\hline здания & 53,4 & 53,0 \\
\hline сооружения & 25,2 & 25,6 \\
\hline машины и оборудование & 12,3 & 12,8 \\
\hline транспортные средства & 6,9 & 7,4 \\
\hline $\begin{array}{l}\text { производства и распределения газообразного топлива } \\
\text { из них: }\end{array}$ & 100 & 100 \\
\hline здания & 7,2 & 6,7 \\
\hline сооружения & 80,3 & 81,8 \\
\hline машины и оборудование & 8,6 & 8,2 \\
\hline транспортные средства & 3,2 & 3,1 \\
\hline $\begin{array}{l}\text { производства, передачи и распределения пара } \\
\text { и горячей воды; кондиционирование воздуха }\end{array}$ & 100 & 100 \\
\hline \multicolumn{3}{|l|}{ из них: } \\
\hline здания & 17,1 & 16,5 \\
\hline сооружения & 57,0 & 58,1 \\
\hline машины и оборудование & 23,5 & 23,4 \\
\hline транспортные средства & 1,5 & 1,6 \\
\hline забора, очистки и распределения воды & 100 & 100 \\
\hline \multicolumn{3}{|l|}{ из них: } \\
\hline здания & 9,9 & 9,6 \\
\hline сооружения & 79,0 & 78,4 \\
\hline машины и оборудование & 9,5 & 10,4 \\
\hline транспортные средства & 1,1 & 1,1 \\
\hline $\begin{array}{l}\text { управления эксплуатацией нежилого фонда } \\
\text { за вознаграждение или на договорной основе }\end{array}$ & 100 & 100 \\
\hline \multicolumn{3}{|l|}{ из них: } \\
\hline здания & 72,6 & 73,1 \\
\hline сооружения & 11,3 & 10,9 \\
\hline машины и оборудование & 10,0 & 12,4 \\
\hline транспортные средства & 2,0 & 1,7 \\
\hline сбора и обработки сточных вод & 100 & 100 \\
\hline \multicolumn{3}{|l|}{ из них: } \\
\hline здания & 7,5 & 7,1 \\
\hline сооружения & 80,9 & 81,4 \\
\hline машины и оборудование & 8,5 & 8,5 \\
\hline транспортные средства & 2,6 & 2,8 \\
\hline $\begin{array}{l}\text { деятельности по предоставлению прочих персональных услуг } \\
\text { из них: }\end{array}$ & 100 & 100 \\
\hline здания & 47,1 & 48,4 \\
\hline сооружения & 11,9 & 12,3 \\
\hline машины и оборудование & 20,0 & 28,4 \\
\hline транспортные средства & 5,1 & 4,5 \\
\hline
\end{tabular}

1) По коммерческим организациям (без субъектов малого предпринимательства).

2) В соответствии с Общероссийским классификатором видов экономической деятельности (ОКВЭД-2) ОК 029-2014. 


\subsection{6. ВИДОВАЯ СТРУКТУРА ОСНОВНЫХ ФОНДОВ КОММЕРЧЕСКИХ ОРГАНИЗАЦИЙ ЖИЛИЩНО-КОММУНАЛЬНОГО ХОЗЯЙСТВА ПО ВИДАМ ЭКОНОМИЧЕСКОЙ ДЕЯТЕЛЬНОСТИ На КОНец 2018 г. ${ }^{1)}$}

(в процентах)

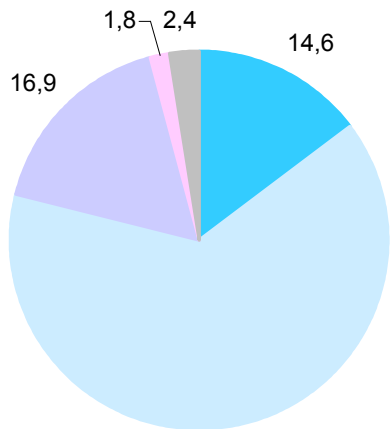

Здания

Сооружения

Машины и оборудование

Транспортные средства

Другие виды основных фондов

64,3

\footnotetext{
1) Без субъектов малого предпринимательства.
}

\section{БЛАГОУСТРОЙСТВО ГОРОДСКИХ ПОСЕЛЕНИЙ}

\subsection{7. ОСНОВНЫЕ ПОКАЗАТЕЛИ ВНЕШНЕГО ГОРОДСКОГО БЛАГОУСТРОЙСТВА}

(на конец года)

\begin{tabular}{|c|c|c|c|c|c|}
\hline & 2010 & 2015 & 2016 & 2017 & 2018 \\
\hline \multicolumn{6}{|l|}{$\begin{array}{l}\text { Общая площадь городских земель } \\
\text { в пределах городской черты }\end{array}$} \\
\hline всего, тыс. га & 8595 & 9184 & 9270 & 9308 & 9584 \\
\hline в том числе застроенная & 3260 & 3529 & 3557 & 3586 & 3674 \\
\hline $\begin{array}{l}\text { в процентах от общей площади } \\
\text { Общая площадь зеленых насаждений в пределах } \\
\text { городской черты }\end{array}$ & 38 & 38 & 38 & 39 & 38 \\
\hline всего, тыс. га & 2144 & 2332 & 2372 & 2259 & 2267 \\
\hline в процентах от общей площади & 25 & 25 & 26 & 24 & 24 \\
\hline $\begin{array}{l}\text { Из общей площади зеленых насаждений - } \\
\text { площадь насаждений общего пользования, }\end{array}$ & & & & & \\
\hline $\begin{array}{l}\text { тыс. га } \\
\text { Число специальных автомобилей, используемых } \\
\text { для уборки территорий и вывоза коммунальных }\end{array}$ & 212 & 238 & 250 & 250 & 243 \\
\hline 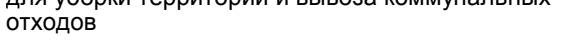 & 63094 & 76408 & 77393 & 84973 & 87780 \\
\hline $\begin{array}{l}\text { Общая протяженность улиц, проездов, } \\
\text { набережных, тыс. км } \\
\text { в том числе: }\end{array}$ & 241 & 254 & 257 & 259 & 262 \\
\hline замощенных частей & 171 & 188 & 190 & 191 & 194 \\
\hline из них с усовершенствованным покрытием & 141 & 148 & 151 & 152 & 154 \\
\hline в процентах от общей протяженности & 58 & 58 & 59 & 59 & 59 \\
\hline освещенных частей & 160 & 172 & 176 & 179 & 183 \\
\hline в процентах от общей протяж & 66 & 68 & 69 & 69 & 70 \\
\hline
\end{tabular}




\section{4. СТРОИТЕЛЬСТВО И РЫНОК ЖИЛЬЯ}

\section{СТРОИТЕЛЬСТВО ЖИЛЬЯ И КОММУНАЛЬНЫХ ОБЪЕКТОВ}

\section{1. ВВОД В ДЕЙСТВИЕ ЖИЛЫХ ДОМОВ}

\begin{tabular}{c|c|c|c|c|c}
\hline Годы & $\begin{array}{c}\text { Всего, млн м } \\
\text { общей площади } \\
\text { жилых помещений }\end{array}$ & \multicolumn{3}{|c|}{ в том числе } & \multicolumn{2}{|c|}{$\begin{array}{c}\text { Удельный вес в общем вводе жилых } \\
\text { домов, построенных, процентов }\end{array}$} \\
\cline { 3 - 6 } & $\begin{array}{c}\text { населением за } \\
\text { счет собственных } \\
\text { и привлеченных } \\
\text { средств }\end{array}$ & $\begin{array}{c}\text { жилищно- } \\
\text { строительными } \\
\text { кооперативами }\end{array}$ & $\begin{array}{c}\text { населением за } \\
\text { счет собственных } \\
\text { и привлеченных } \\
\text { средств }\end{array}$ & $\begin{array}{c}\text { жилых домов } \\
\text { жилищно- } \\
\text { строительных } \\
\text { кооперативов }\end{array}$ \\
\hline 2010 & 58,4 & 25,5 & 0,3 & 43,7 & 0,6 \\
2015 & 85,3 & 35,2 & 0,6 & 41,2 & 0,7 \\
2016 & 80,2 & 31,8 & 1,0 & 39,6 & 1,2 \\
2017 & 79,2 & 33,0 & 0,8 & 41,6 & 1,0 \\
2018 & 75,7 & 32,4 & 0,4 & 42,9 & 0,5 \\
\hline
\end{tabular}

\section{2. ИНДЕКСЫ ВВОДА В ДЕЙСТВИЕ ЖИЛЫХ ДОМОВ}

$$
(1990=100)
$$

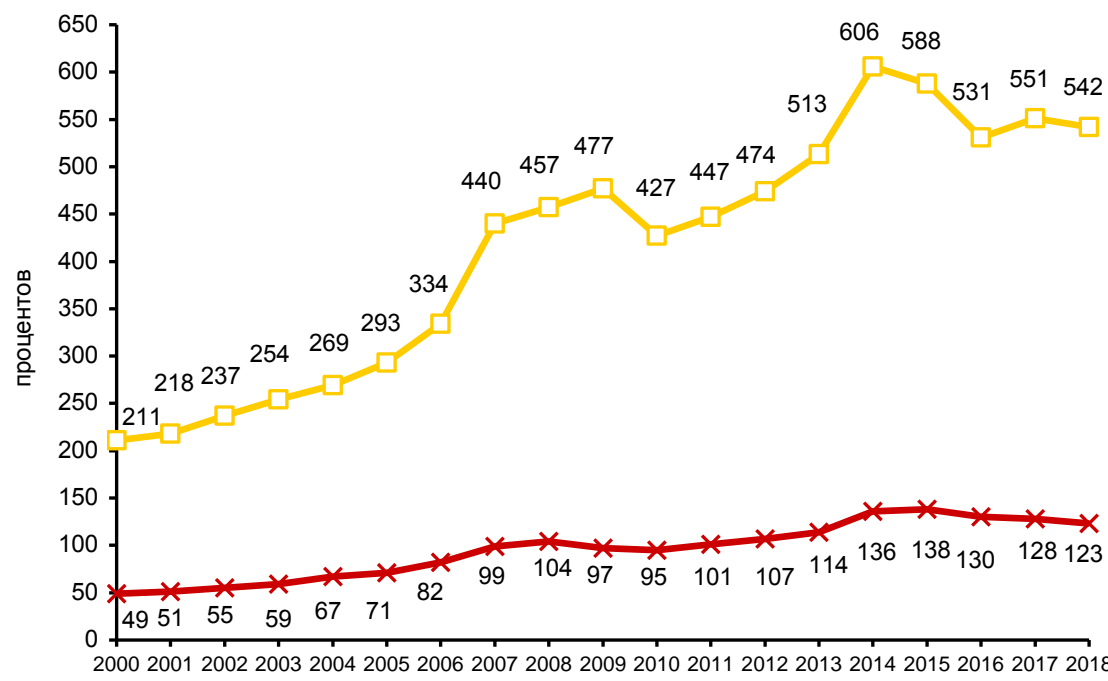




\section{3. ВВОД В ДЕЙСТВИЕ ЖИЛЫХ ДОМОВ ОРГАНИЗАЦИЯМИ РАЗЛИЧНЫХ ФОРМ СОБСТВЕННОСТИ И НАСЕЛЕНИЕМ \\ (миллионов квадратных метров общей площади жилых помещений)}

\begin{tabular}{|c|c|c|c|c|c|}
\hline & 2010 & 2015 & 2016 & 2017 & 2018 \\
\hline $\begin{array}{l}\text { Введено - всего } \\
\text { в том числе: } \\
\text { организациями всех фрорм } \\
\text { собственности }\end{array}$ & 58,4 & 85,3 & 80,2 & 79,2 & 75,7 \\
\hline из них: & & & & & \\
\hline $\begin{array}{l}\text { государственной } \\
\text { в том числе: }\end{array}$ & 3,5 & 2,5 & 2,2 & 2,4 & 1,1 \\
\hline $\begin{array}{l}\text { федеральной } \\
\text { собственности субъектов }\end{array}$ & 2,0 & 1,0 & 1,0 & 1,5 & 0,5 \\
\hline Российской Федерации & 1,5 & 1,5 & 1,2 & 0,9 & 0,6 \\
\hline муниципальной & 2,0 & 1,9 & 1,7 & 1,9 & 0,8 \\
\hline смешанной российской & 1,0 & 0,6 & 0,5 & 0,5 & 0,6 \\
\hline частной & 24,9 & 41,6 & 40,2 & 38,7 & 38,9 \\
\hline $\begin{array}{l}\text { населением за счет собственных } \\
\text { и привлеченных средств }\end{array}$ & 25,5 & 35,2 & 31,8 & 33,0 & 32,4 \\
\hline
\end{tabular}

\section{4. ВВОД В ДЕЙСТВИЕ ЖИЛЫХ ДОМОВ В расчете на 1000 человек населения}

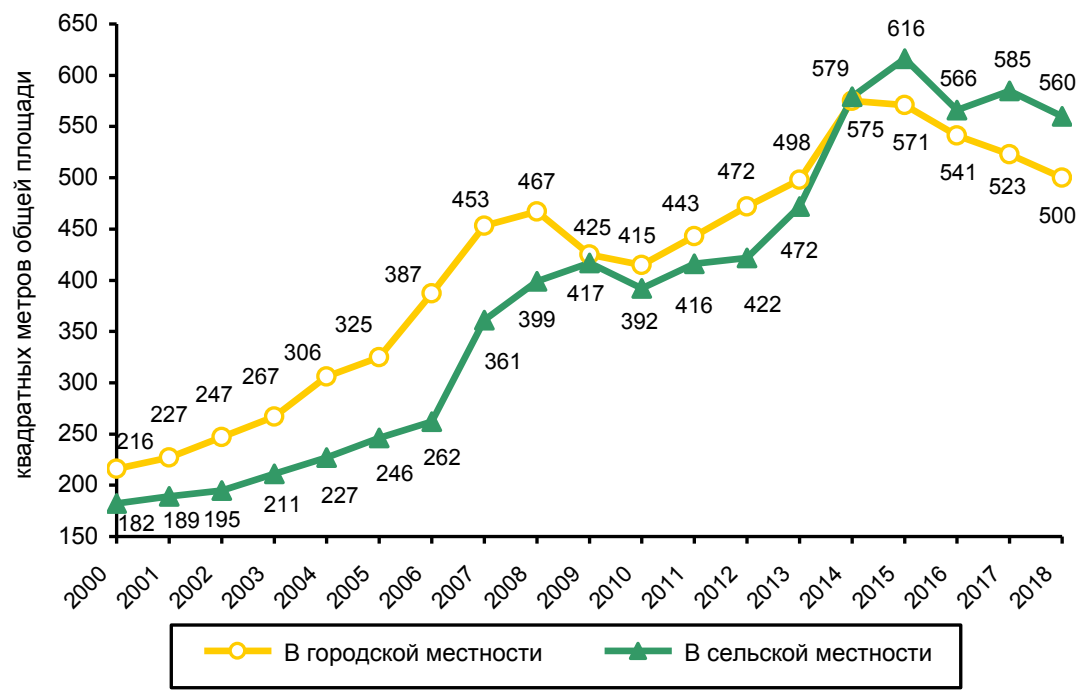




\section{5. ВВОД В ДЕЙСТВИЕ ЖИЛЫХ ДОМОВ}

В ГОРОДСКОЙ И СЕЛЬСКОЙ МЕСТНОСТИ

(миллионов квадратных метров общей площади жилых помещений)

\begin{tabular}{c|c|c}
\hline Годы & Bсего & $\begin{array}{c}\text { в том числе } \\
\text { населением за счет } \\
\text { собственных иривлеченных } \\
\text { средств }\end{array}$ \\
\hline 2010 & 43,7 & 12,7 \\
2015 & 62,0 & 16,3 \\
2016 & 58,8 & 14,9 \\
2017 & 57,2 & 15,5 \\
2018 & 54,7 & 14,7 \\
2010 & В сельской местности \\
2015 & 14,7 & 12,8 \\
2016 & 23,3 & 18,9 \\
2017 & 21,4 & 16,9 \\
2018 & 22,0 & 17,5 \\
\hline
\end{tabular}

\section{6. ТЕМПЫ РОСТА (СНИЖЕНИЯ) ВВОДА В ДЕЙСТВИЕ ЖИЛЫХ ДОМОВ}

(в процентах к предыдущему году)

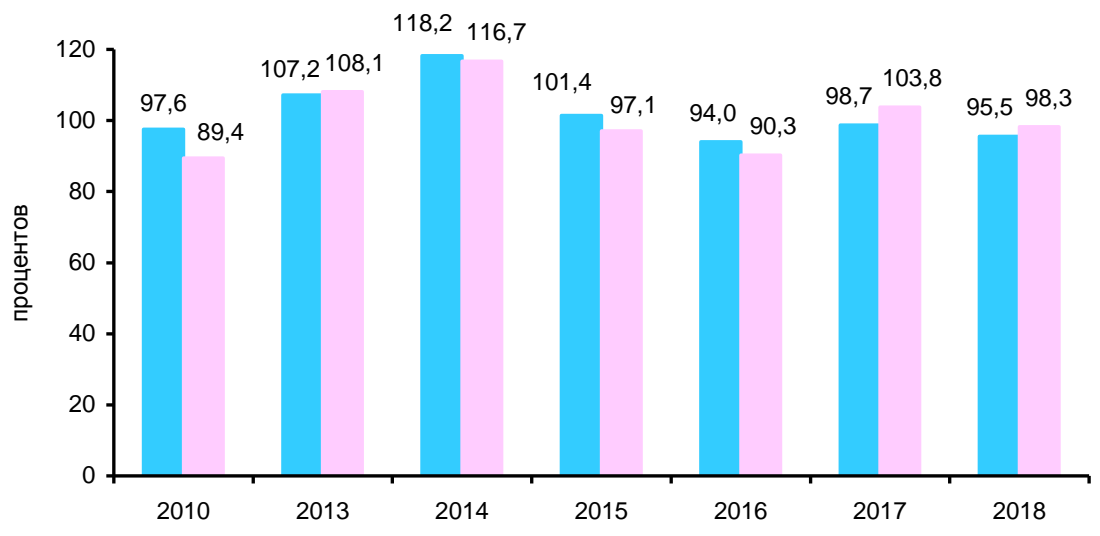

Введено всего

в том числе населением за счет собственных и привлеченных средств 


\section{7. СТРОИТЕЛЬСТВО ЖИЛЫХ ДОМОВ ПО ТИПАМ ЗДАНИЙ (БЕЗ ЖИЛЫХ ДОМОВ, ПОСТРОЕННЫХ ИНДИВИДУАЛЬНЫМИ ЗАСТРОЙЩИКАМИ) ${ }^{1)}$}

(тысяч квадратных метров общей площади жилых помещений)

\begin{tabular}{l|r|r|r|r}
\hline & \multicolumn{1}{|c|}{2015} & 2016 & \multicolumn{1}{c}{2017} & 2018 \\
\hline Жилые здания многоквартирные & 49325,1 & 48000,9 & 45830,0 & 42922,6 \\
$\quad$ из них: & & & \\
малоэтажные многоквартирные блокированные & 984,6 & 649,6 & 542,4 & 459,3 \\
$\begin{array}{l}\text { малоэтажные многоквартирные, состоящие } \\
\text { из блок-секций }\end{array}$ & 1368,6 & 1094,2 & 584,5 & 458,7 \\
$\begin{array}{l}\text { Жилые здания индивидуальные } \\
\text { (предназначенные для проживания одной семьи) }\end{array}$ & 587,2 & 302,0 & 242,8 & 159,3 \\
$\quad$ из них блокированные & 159,7 & 77,8 & 101,3 & 65,9 \\
Жилье экономического класса & & & \\
\hline
\end{tabular}

1) Данные по вводу в действие жилых домов по типам зданий приведены в том числе из общего ввода, отраженного в таблице № 4.1 .

2) С июня 2016 г. - по данным Минстроя России.

\section{8. ЧИСЛО ПОСТРОЕННЫХ КВАРТИР И ИХ СРЕДНИЙ РАЗМЕР}

\begin{tabular}{|c|c|c|c|c|c|}
\hline & 2010 & 2015 & 2016 & 2017 & 2018 \\
\hline & \multicolumn{5}{|c|}{ Всего } \\
\hline Число квартир, тыс. & 717 & 1195 & 1167 & 1139 & 1076 \\
\hline \multicolumn{6}{|l|}{$\begin{array}{l}\text { Из них квартиры по видам, в процентах } \\
\text { от общего ввода: }\end{array}$} \\
\hline однокомнатные & 34 & 43 & 46 & 46 & 47 \\
\hline двухкомнатные & 32 & 30 & 29 & 29 & 29 \\
\hline трехкомнатные & 23 & 18 & 17 & 16 & 16 \\
\hline четырехкомнатные и более & 11 & 9 & 8 & 9 & 8 \\
\hline \multirow[t]{2}{*}{ Их средний размер, м² общей площади } & 81,5 & 71,4 & 68,7 & 69,6 & 70,3 \\
\hline & \multicolumn{5}{|c|}{ Жилищно-строительными кооперативами } \\
\hline Число квартир, тыс. & 5 & 11 & 18 & 13 & 7 \\
\hline \multirow[t]{2}{*}{ Их средний размер, м² общей площади } & 69,1 & 54,9 & 55,4 & 61,3 & 57,5 \\
\hline & \multicolumn{5}{|c|}{$\begin{array}{l}\text { Населением за счет собственных } \\
\text { и привлеченных средств }\end{array}$} \\
\hline Число квартир, тыс. & 192 & 272 & 251 & 244 & 233 \\
\hline Их средний размер, м $^{2}$ общей площади & 132,6 & 129,6 & 126,7 & 135,1 & 139,1 \\
\hline
\end{tabular}




\section{9. СРЕДНЯЯ ФАКТИЧЕСКАЯ СТОИМОСТЬ СТРОИТЕЛЬСТВА ОДНОГО КВАДРАТНОГО МЕТРА ОБЩЕЙ ПЛОЩАДИ ЖИЛЫХ ПОМЕЩЕНИЙ ВО ВВЕДЕННЫХ В ЭКСПЛУАТАЦИЮ ЖИЛЫХ ДОМАХ ${ }^{1)}$}

(рублей)

\begin{tabular}{l|r|r|r|r|r}
\hline & 2010 & 2015 & 2016 & 2017 & 2018 \\
\hline Всего & $\mathbf{3 1 8 7 7}$ & $\mathbf{3 9 2 5 8}$ & $\mathbf{4 0 8 9 0}$ & $\mathbf{4 1 4 5 9}$ & $\mathbf{4 1 3 5 8}$ \\
в городах и поселках городского типа & 31844 & 39531 & 41131 & 41773 & 41658 \\
в сельской местности & 32391 & 36834 & 38857 & 38950 & 37553 \\
\hline
\end{tabular}

1) Жилые дома квартирного типа без пристроек, надстроек и встроенных помещений и без жилых домов, построенных индивидуальными застройщиками.

\subsection{0. ЖИЛЫЕ ДОМА, НАХОДЯЩИЕСЯ В НЕЗАВЕРШЕННОМ СТРОИТЕЛЬСТВЕ ${ }^{1)}$} (на конец года)

\begin{tabular}{l|c|c|c|c|c}
\hline & 2010 & 2015 & 2016 & 2017 & 2018 \\
\hline Число жилых домов, тыс. & 11,6 & 7,7 & 7,1 & 6,3 & 7,9 \\
Их общая площадь: & & & & & \\
млн м² & 29,7 & 34,7 & 37,3 & 37,5 & 52,9 \\
в процентах к предыдущему году & 87,6 & 96,0 & 107,4 & 100,5 & 141,0 \\
\hline
\end{tabular}

1) Без строящихся населением.

\subsection{1. ВВОД В ДЕЙСТВИЕ ОБЪЕКТОВ КОММУНАЛЬНОГО ХОЗЯЙСТВА}

(километров)

\begin{tabular}{c|c|c|c|c|c|c}
\hline Годы & $\begin{array}{c}\text { Водопровод- } \\
\text { ные сети } \\
\text { всего }\end{array}$ & $\begin{array}{c}\text { в том числе } \\
\text { в сельской } \\
\text { местности }\end{array}$ & $\begin{array}{c}\text { Газовые } \\
\text { сети - всего }\end{array}$ & $\begin{array}{c}\text { в том числе } \\
\text { в сельской } \\
\text { местности }\end{array}$ & $\begin{array}{c}\text { Канализа- } \\
\text { ционные } \\
\text { сети }\end{array}$ & $\begin{array}{c}\text { Тепловые } \\
\text { сети }\end{array}$ \\
\hline 2010 & 2234,4 & 1522,0 & 14016,7 & 11068,5 & 496,3 & 204,3 \\
2015 & 2697,0 & 1868,6 & 9680,1 & 7173,2 & 471,8 & 106,1 \\
2016 & 1675,2 & 1088,7 & 8724,0 & 6589,0 & 445,8 & 170,1 \\
2017 & 1397,0 & 932,2 & 7501,3 & 5749,2 & 437,8 & 213,8 \\
2018 & 1499,0 & 921,1 & 8043,4 & 6277,2 & 363,5 & 173,5 \\
\hline
\end{tabular}




\section{РЫнок жилья}

\subsection{2. ОЦЕНКА ДОМОХОЗЯЙСТВАМИ СОСТОЯНИЯ ЗАНИМАЕМОГО ИМИ ЖИЛОГО ПОМЕЩЕНИЯ ПО НАЛИЧИЮ И ЧИСЛУ ДЕТЕЙ \\ В ВОЗРАСТЕ до 18 лет}

(по итогам Комплексного наблюдения условий жизни населения; в процентах)

\begin{tabular}{|c|c|c|c|c|c|}
\hline & \multirow{3}{*}{$\begin{array}{c}\text { Все } \\
\text { домохозяй- } \\
\text { ства }\end{array}$} & \multicolumn{4}{|c|}{ в том числе домохозяйства } \\
\hline & & \multirow[t]{2}{*}{ без детей } & \multirow[t]{2}{*}{ с детьми } & \multicolumn{2}{|c|}{ из них } \\
\hline & & & & $\begin{array}{l}\text { с } 3 \text { и более } \\
\text { детьми }\end{array}$ & $\begin{array}{l}\text { с } 5 \text { и более } \\
\text { детьми }\end{array}$ \\
\hline $\begin{array}{l}\text { Все домохозяйства } \\
\text { из них домохозяйства, } \\
\text { указавшие на: }\end{array}$ & 100 & 100 & 100 & 100 & 100 \\
\hline недостаток тепла & 10,7 & 10,4 & 11,2 & 13,1 & 20,8 \\
\hline $\begin{array}{l}\text { недостаток солнечного } \\
\text { света }\end{array}$ & 7,5 & 7,3 & 7,8 & 8,9 & 2,3 \\
\hline $\begin{array}{l}\text { сырость (промерзание) } \\
\text { стен, полов }\end{array}$ & 8,2 & 7,7 & 9,1 & 12,6 & 14,4 \\
\hline $\begin{array}{l}\text { наличие насекомых } \\
\text { (грызунов) }\end{array}$ & 5,5 & 5,1 & 6,2 & 7,9 & 9,3 \\
\hline $\begin{array}{l}\text { шум, загрязнение воздуха, } \\
\text { пыль, сажа с улицы } \\
\text { (транспорт, предприятия, } \\
\text { магазины) }\end{array}$ & 13,4 & 13,0 & 14,0 & 11,8 & 14,9 \\
\hline 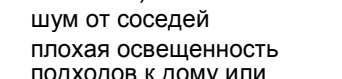 & 10,9 & 10,9 & 11,1 & 7,5 & 2,5 \\
\hline $\begin{array}{l}\text { подходов к дому или } \\
\text { в подъезде } \\
\text { нарушение общественного }\end{array}$ & 15,6 & 15,0 & 16,7 & 19,9 & 31,3 \\
\hline $\begin{array}{l}\text { порядка вблизи дома или } \\
\text { в подъезде }\end{array}$ & 5,4 & 5,1 & 5,9 & 5,6 & 0,0 \\
\hline $\begin{array}{l}\text { не испытываем } \\
\text { ничего из перечисленного }\end{array}$ & 58,9 & 59,9 & 56,8 & 55,6 & 51,1 \\
\hline $\begin{array}{l}\text { Из числа всех домохозяйств } \\
\text { оценили состояние своего } \\
\text { жилого помещения как: }\end{array}$ & & & & & \\
\hline отличное & 5,9 & 5,5 & 6,6 & 6,0 & 0,0 \\
\hline xорошеe & 42,8 & 41,8 & 44,8 & 38,1 & 41,7 \\
\hline удовлетворительное & 46,3 & 47,7 & 43,4 & 45,4 & 35,5 \\
\hline плохое & 4,4 & 4,4 & 4,4 & 8,3 & 18,6 \\
\hline очень плохое & 0,6 & 0,6 & 0,7 & 2,1 & 4,2 \\
\hline $\begin{array}{l}\text { Все домохозяйства } \\
\text { В том числе, указавшие, } \\
\text { что: }\end{array}$ & 100 & 100 & 100 & 100 & 100 \\
\hline $\begin{array}{l}\text { жилищные условия } \\
\text { в целом устраивают } \\
\text { испытывают потребность }\end{array}$ & 70,0 & 78,2 & 54,0 & 38,9 & 20,9 \\
\hline $\begin{array}{l}\text { в улучшении жилищных } \\
\text { условий }\end{array}$ & 29,6 & 21,4 & 45,7 & 61,1 & 79,1 \\
\hline не определено & 0,4 & 0,4 & 0,3 & 0,0 & 0,0 \\
\hline
\end{tabular}




\subsection{3. РАСПРЕДЕЛЕНИЕ ДОМОХОЗЯЙСТВ ПО НАМЕРЕНИЮ И ИСТОЧНИКАМ ДЕНЕЖНЫХ СРЕДСТВ ДЛЯ УЛУЧШЕНИЯ СвОИХ жилищныХ УслОВиЙ в 2018 г.}

(по итогам Комплексного наблюдения условий жизни населения; в процентах)

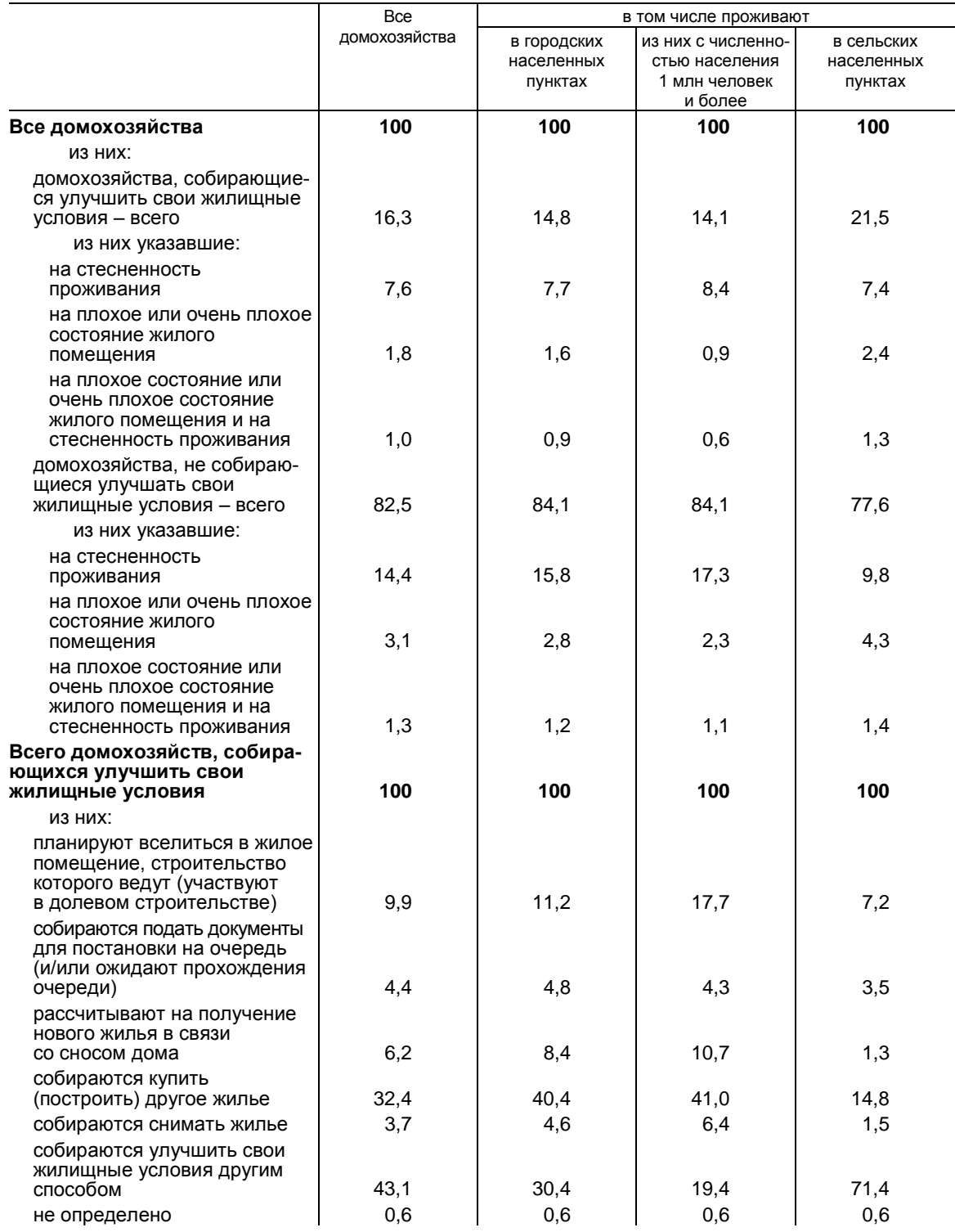


Продолжение табл. 4.13

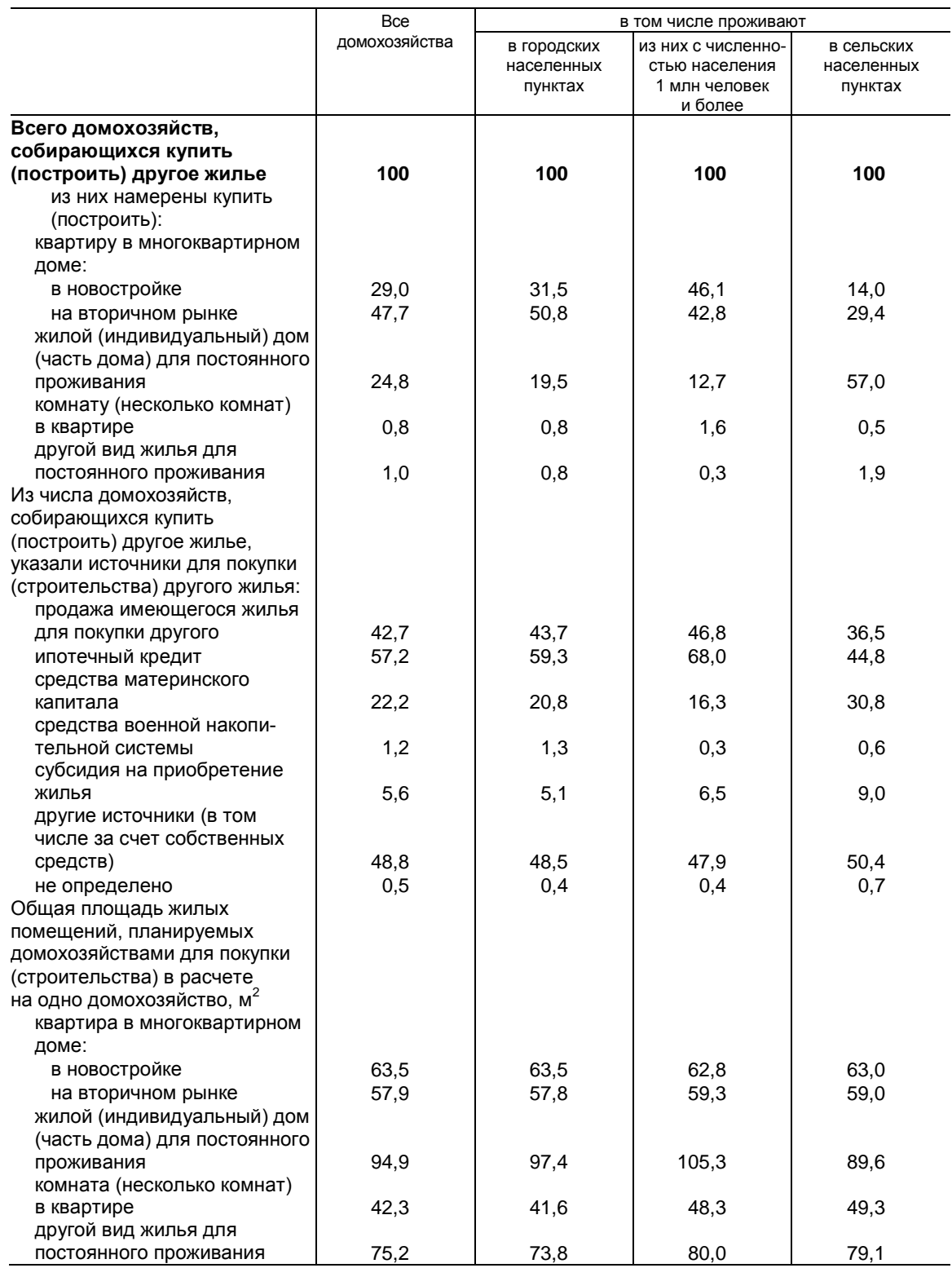




\subsection{4. ОЦЕНКА ДОМОХОЗЯЙСТВАМИ СОСТОЯНИЯ ЗАНИМАЕМОГО ИМИ ЖИЛОГО ПОМЕЩЕНИЯ В 2018 Г.}

(по итогам Комплексного наблюдения условий жизни населения; в процентах)

\begin{tabular}{|c|c|c|c|c|}
\hline & \multirow{2}{*}{$\begin{array}{c}\text { Все } \\
\text { домохозяйства }\end{array}$} & \multicolumn{3}{|c|}{ в том числе проживают } \\
\hline & & $\begin{array}{l}\text { в городских } \\
\text { населенных } \\
\text { пунктах }\end{array}$ & $\begin{array}{c}\text { из них с численно- } \\
\text { стью населения } \\
1 \text { млн человек } \\
\text { и более } \\
\end{array}$ & $\begin{array}{l}\text { в сельских } \\
\text { населенных } \\
\text { пунктах }\end{array}$ \\
\hline $\begin{array}{l}\text { Все домохозяйства } \\
\text { из них: }\end{array}$ & 100 & 100 & 100 & 100 \\
\hline домохозяйства, указавшие на: & & & & \\
\hline $\begin{array}{l}\text { недостаток тепла } \\
\text { недостаток солнечного }\end{array}$ & 10,7 & 10,7 & 8,1 & 10,6 \\
\hline $\begin{array}{l}\text { света } \\
\text { сырость (промерзание) }\end{array}$ & 7,5 & 8,3 & 10,1 & 4,9 \\
\hline стен, полов & 8,2 & 7,3 & 4,2 & 10,9 \\
\hline $\begin{array}{l}\text { наличие насекомых } \\
\text { (грызунов) }\end{array}$ & 5,5 & 4,9 & 2,8 & 7,2 \\
\hline $\begin{array}{l}\text { шум, загрязнение воздуха, } \\
\text { пыль, сажа с улицы } \\
\text { (транспорт, предприятия, } \\
\text { магазины) }\end{array}$ & 13,4 & 15,4 & 16,3 & 6,7 \\
\hline $\begin{array}{l}\text { шум от соседей } \\
\text { плохая освещенность } \\
\text { подходов к дому или }\end{array}$ & 10,9 & 12,8 & 16,8 & 4,8 \\
\hline $\begin{array}{l}\text { в подъезде } \\
\text { нарушение общественного } \\
\text { порядка вблизи дома или }\end{array}$ & 15,6 & 15,1 & 12,8 & 17,0 \\
\hline в подъезде & 5,4 & 6,5 & 6,5 & 1,8 \\
\hline $\begin{array}{l}\text { домохозяйства, указавшие } \\
\text { на все или на большинство } \\
\text { перечисленных недостатков }\end{array}$ & & & & \\
\hline $\begin{array}{l}\text { в жилом помещении } \\
\text { Из числа всех домохозяйств } \\
\text { оценили состояние своего } \\
\text { жилого помещения как: }\end{array}$ & 0,2 & 0,2 & 0,1 & 0,0 \\
\hline отличное & 5,9 & 6,2 & 6,6 & 4,9 \\
\hline хорошее & 42,8 & 44,1 & 44,5 & 38,7 \\
\hline удовлетворительное & 46,3 & 45,3 & 45,6 & 49,5 \\
\hline плохое & 4,4 & 3,8 & 2,8 & 6,2 \\
\hline очень плохое & 0,6 & 0,6 & 0,4 & 0,7 \\
\hline $\begin{array}{l}\text { Домохозяйства, указавшие } \\
\text { при оценке условий } \\
\text { проживания и состояния } \\
\text { своего жилища: }\end{array}$ & & & & \\
\hline $\begin{array}{l}\text { только на стесненность } \\
\text { проживания }\end{array}$ & 10,1 & 10,8 & 12,6 & 7,7 \\
\hline $\begin{array}{l}\text { на стесненность проживания } \\
\text { и на плохое или очень плохое } \\
\text { состояние своего жилого }\end{array}$ & & & & \\
\hline помещения & 0,3 & 0,2 & 0,2 & 0,6 \\
\hline $\begin{array}{l}\text { Все домохозяйства } \\
\text { в том числе, указавшие, что: } \\
\text { жилищные условия в целом }\end{array}$ & 100 & 100 & 100 & 100 \\
\hline $\begin{array}{l}\text { удовлетворяют } \\
\text { испытывают потребность в }\end{array}$ & 70,0 & 71,1 & 70,9 & 66,6 \\
\hline улучшении жилищных условий & 29,6 & 28,5 & 28,4 & 33,2 \\
\hline не определено & 0,4 & 0,4 & 0,6 & 0,2 \\
\hline
\end{tabular}


Продолжение табл. 4.14

\begin{tabular}{|c|c|c|c|c|}
\hline & \multirow{2}{*}{$\begin{array}{c}\text { Все } \\
\text { домохозяйства }\end{array}$} & \multicolumn{3}{|c|}{ в том числе проживают } \\
\hline & & $\begin{array}{l}\text { в городских } \\
\text { населенных } \\
\text { пунктах }\end{array}$ & \begin{tabular}{|c|} 
из них с численно- \\
стью населения \\
1 млн человек \\
и более \\
\end{tabular} & $\begin{array}{l}\text { в сельских } \\
\text { населенных } \\
\text { пунктах }\end{array}$ \\
\hline $\begin{array}{l}\text { Домохозяйства, проживаю- } \\
\text { щие в многоквартирных } \\
\text { домах (включая общежития) - }\end{array}$ & & & & \\
\hline $\begin{array}{l}\text { всего } \\
\text { из них: } \\
\text { домохозяйства указавшие на: }\end{array}$ & 100 & 100 & 100 & 100 \\
\hline $\begin{array}{l}\text { домохозяйства, указавшие на: } \\
\text { недостаток тепла }\end{array}$ & 11,7 & 11,1 & 8,2 & 16,9 \\
\hline $\begin{array}{l}\text { недостаток солнечного } \\
\text { света }\end{array}$ & 8,6 & 8,7 & 10,1 & 7,2 \\
\hline $\begin{array}{l}\text { сырость (промерзание) } \\
\text { стен, полов }\end{array}$ & 7,6 & 6,8 & 4,0 & 15,1 \\
\hline $\begin{array}{l}\text { наличие насекомых } \\
\text { (грызунов) }\end{array}$ & 4,8 & 4,6 & 2,7 & 6,4 \\
\hline $\begin{array}{l}\text { шум, загрязнение воздуха, } \\
\text { пыль, сажа с улицы } \\
\text { (транспорт, предприятия, } \\
\text { магазины) }\end{array}$ & 14,9 & 15,8 & 16,3 & 7,1 \\
\hline $\begin{array}{l}\text { шум от соседей } \\
\text { плохая освещенность } \\
\text { подходов к дому }\end{array}$ & 13,9 & 14,2 & 16,9 & 11,2 \\
\hline $\begin{array}{l}\text { или в подъезде } \\
\text { нарушение общественного }\end{array}$ & 15,4 & 14,7 & 12,6 & 21,2 \\
\hline $\begin{array}{l}\text { порядка вблизи дома } \\
\text { или в подъезде }\end{array}$ & 6,7 & 7,0 & 6,4 & 4,1 \\
\hline $\begin{array}{l}\text { домохозяйства, указавшие } \\
\text { на все или на большинство } \\
\text { перечисленных недостатков } \\
\text { в жилом помещении }\end{array}$ & 0,2 & 0,2 & 0,1 & 0,1 \\
\hline $\begin{array}{l}\text { Из числа домохозяйств, } \\
\text { проживающих в многоквар- } \\
\text { тирных домах (включая } \\
\text { общежития), оценили } \\
\text { состояние своего жилого } \\
\text { помещения как: }\end{array}$ & & & & \\
\hline отличное & 5,9 & 6,2 & 6,6 & 3,5 \\
\hline хорошее & 43,6 & 44,6 & 44,5 & 34,3 \\
\hline удовлетворительное & 46,1 & 45,2 & 45,6 & 55,1 \\
\hline плохое & 3,8 & 3,5 & 2,8 & 6,1 \\
\hline очень плохое & 0,6 & 0,6 & 0,4 & 1,1 \\
\hline $\begin{array}{l}\text { Домохозяйства, проживаю- } \\
\text { щие в многоквартирных } \\
\text { домах (включая общежития) } \\
\text { и указавшие при оценке } \\
\text { условий проживания } \\
\text { и состояния своего жилища: }\end{array}$ & & & & \\
\hline $\begin{array}{l}\text { только на стесненность } \\
\text { проживания }\end{array}$ & 11,1 & 11,4 & 12,6 & 8,5 \\
\hline $\begin{array}{l}\text { на стесненность проживания } \\
\text { и на плохое или очень плохое } \\
\text { состояние своего жилого } \\
\text { помещения }\end{array}$ & 0,2 & 0,2 & 0,2 & 0,3 \\
\hline
\end{tabular}


Продолжение табл. 4.14

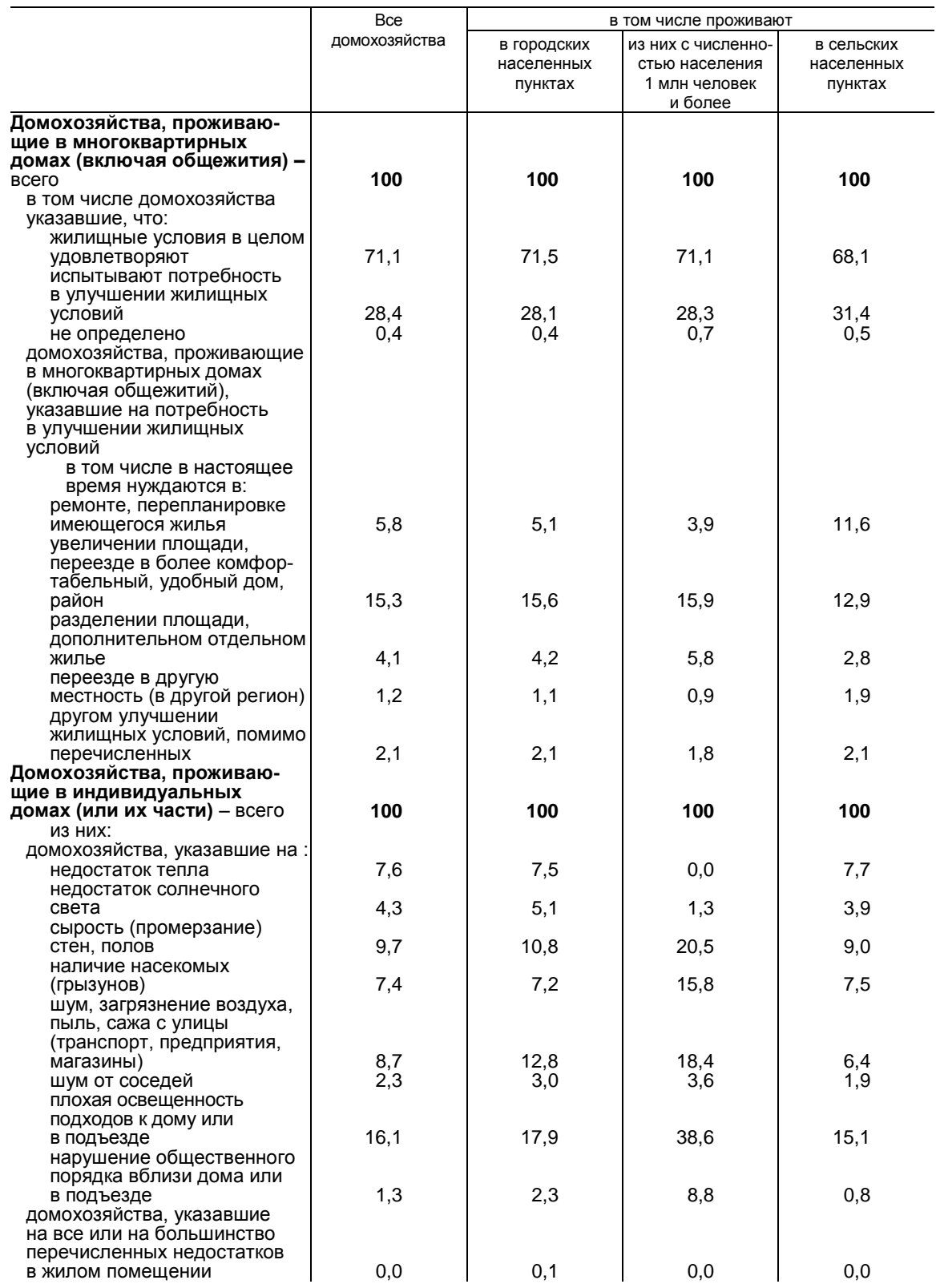


Продолжение табл. 4.14

\begin{tabular}{|c|c|c|c|c|}
\hline & \multirow{2}{*}{$\begin{array}{c}\text { Все } \\
\text { домохозяйства }\end{array}$} & \multicolumn{3}{|c|}{ В том числе проживают } \\
\hline & & $\begin{array}{l}\text { в городских } \\
\text { населенных } \\
\text { пунктах }\end{array}$ & \begin{tabular}{|c|} 
из них с численно- \\
стью населения \\
1 млн человек \\
и более \\
\end{tabular} & $\begin{array}{c}\text { в сельских } \\
\text { населенных } \\
\text { пунктах }\end{array}$ \\
\hline \multicolumn{5}{|l|}{$\begin{array}{l}\text { Из числа домохозяйств, } \\
\text { проживающих в индивиду- } \\
\text { альных домах (или их части), } \\
\text { оценили состояние своего } \\
\text { жилого помещения как: }\end{array}$} \\
\hline отличное & 5,9 & 6,6 & 4,7 & 5,5 \\
\hline хорошее & 40,7 & 40,5 & 46,8 & 40,8 \\
\hline удовлетворительное & 46,7 & 46,1 & 42,2 & 47,0 \\
\hline плохое & 6,2 & 6,2 & 6,3 & 6,2 \\
\hline очень плохое & 0,6 & 0,6 & 0,0 & 0,6 \\
\hline \multicolumn{5}{|l|}{$\begin{array}{l}\text { Домохозяйства, проживающие } \\
\text { в индивидуальных домах } \\
\text { (или их части) и указавшие } \\
\text { при оценке условий } \\
\text { проживания и состояния } \\
\text { своего жилища: }\end{array}$} \\
\hline $\begin{array}{l}\text { только на стесненность } \\
\text { проживания }\end{array}$ & 7,1 & 6,7 & 5,3 & 7,3 \\
\hline $\begin{array}{l}\text { на стесненность проживания } \\
\text { и на плохое или очень плохое } \\
\text { состояние своего жилого }\end{array}$ & & & & \\
\hline помещения & 0,7 & 0,6 & 0,0 & 0,7 \\
\hline $\begin{array}{l}\text { Домохозяйства, проживающие } \\
\text { в индивидуальных домах } \\
\text { (или их части) - всего }\end{array}$ & 100 & 100 & 100 & 100 \\
\hline $\begin{array}{l}\text { в том числе, домохозяйства } \\
\text { указавшие, что: }\end{array}$ & & & & \\
\hline $\begin{array}{l}\text { жилищные условия в целом } \\
\text { удовлетворяют }\end{array}$ & 66,8 & 68,4 & 57,4 & 65,9 \\
\hline $\begin{array}{l}\text { испытывают потребность в } \\
\text { улучшении жилищных условий }\end{array}$ & 33,1 & 31,5 & 42,6 & 34,0 \\
\hline $\begin{array}{l}\text { не определено } \\
\text { Домохозяйства, проживающие } \\
\text { в индивидуальных домах } \\
\text { (или их части), указавшие } \\
\text { на потребность в улучшении } \\
\text { жилищных условий }\end{array}$ & 0,1 & 0,1 & 0,0 & 0,1 \\
\hline $\begin{array}{l}\text { в том числе в настоящее } \\
\text { время нуждаются в: }\end{array}$ & & & & \\
\hline $\begin{array}{l}\text { ремонте, перепланировке } \\
\text { имеющегося жилья }\end{array}$ & 22,2 & 19,2 & 29,3 & 23,9 \\
\hline $\begin{array}{l}\text { увеличении площади, переез- } \\
\text { де в более комфортабельный, } \\
\text { удобный дом, район }\end{array}$ & 7,4 & 8,6 & 5,8 & 6,7 \\
\hline $\begin{array}{l}\text { разделении площади, } \\
\text { дополнительном отдельном }\end{array}$ & & & & \\
\hline жилье & 1,2 & 1,6 & 5,5 & 1,0 \\
\hline $\begin{array}{l}\text { переезде в другую местность } \\
\text { (в другой регион) }\end{array}$ & 0,8 & 0,7 & 1,9 & 0,8 \\
\hline $\begin{array}{l}\text { другом улучшении жилищных } \\
\text { условий, помимо } \\
\text { перечисленных }\end{array}$ & 1,6 & 1,4 & 0,0 & 1,6 \\
\hline
\end{tabular}




\subsection{5. ЖИЛИЩНЫЕ УСЛОВИЯ ДОМОХОЗЯЙСТВ, ИМЕЮЩИХ ДЕТЕЙ \\ В ВОЗРАСТЕ до 18 лет}

(по итогам Комплексного наблюдения условий жизни населения)

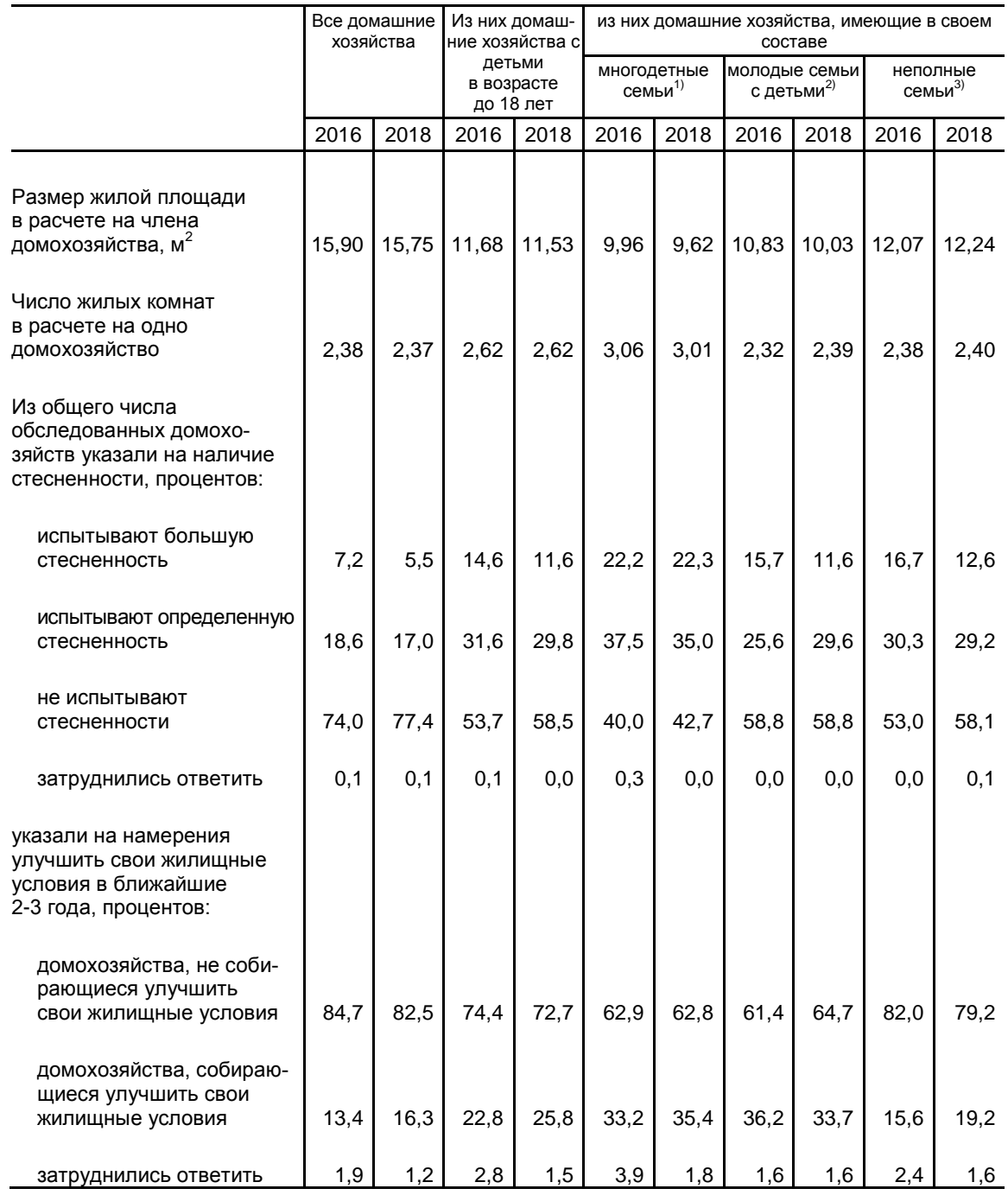

\footnotetext{
1) Многодетная семья - семья, имеющая в своем составе трех и более детей.

2) Молодая семья - возраст супругов от 18 до 25 лет.

${ }^{3)}$ Неполная семья - мать или отец, не состоящий в браке.
} 


\subsection{6. ПРЕДПОЛАГАЕМЫЕ ИСТОЧНИКИ ДЕНЕЖНЫХ СРЕДСТВ НА ПОКУПКУ (СТРОИТЕЛЬСТВО) ЖИЛЬЯ}

(по итогам Комплексного наблюдения условий жизни населения, в процентах к итогу)

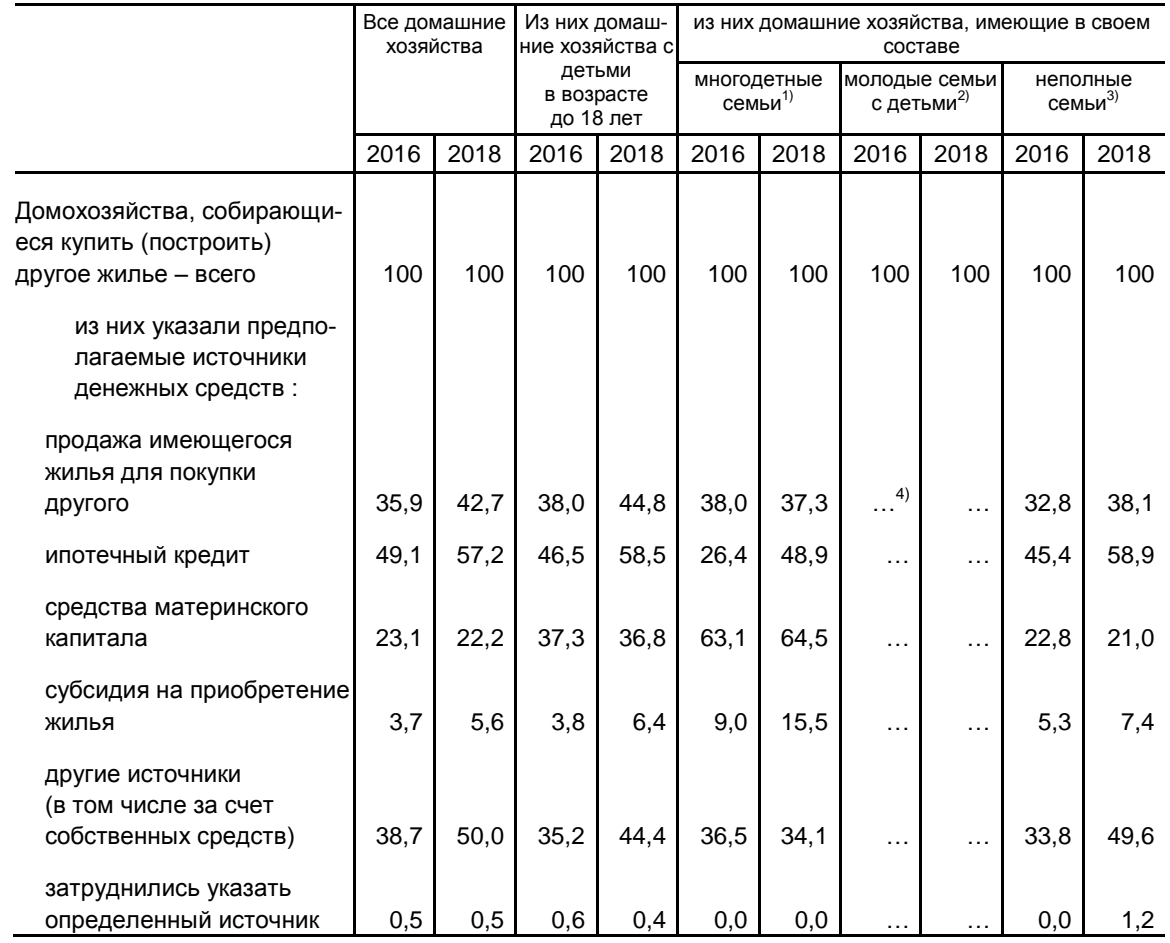

1) Многодетная семья - семья, имеющая в своем составе трех и более детей.

2) Молодая семья - возраст супругов от 18 до 25 лет.

3) Неполная семья - мать или отец, не состоящий в браке.

4) Здесь и далее отметка «...» (многоточие) означает, что число ответов респондентов (наблюдений) составляет менее 50.

\subsection{7. ПРИВАТИЗАЦИЯ ЖИЛИЩНОГО ФОНДА}

\begin{tabular}{l|r|r|r|r|r}
\hline & 2010 & 2015 & 2016 & 2017 & 2018 \\
\hline Число приватизированных жилых & & & & & \\
помещений за год, тыс. & 885 & 449 & 225 & 165 & 95 \\
Их общая площадь, млн м² & 41 & 21 & 10 & 7 & 4 \\
Удельный вес приватизированных жилых & & & & & \\
$\begin{array}{l}\text { помещений в общем числе жилых помещений, } \\
\text { подлежащих приватизации, процентов }\end{array}$ & 8 & 5 & 3 & 2 & 1 \\
\hline
\end{tabular}




\subsection{8.ЧИСЛО ЗАРЕГИСТРИРОВАННЫХ ПРАВ ГРАЖДАН И ЮРИДИЧЕСКИХ ЛИЦ НА ЖИЛЫЕ ПОМЕЩЕНИЯ НА ОСНОВАНИИ ДОГОВОРОВ КУПЛИ-ПРОДАЖИ}

(за год)

\begin{tabular}{l|r|r|r|r|r}
\hline & 2010 & 2015 & 2016 & 2017 & 2018 \\
\hline $\begin{array}{l}\text { Число зарегистрированных прав на жилые } \\
\begin{array}{l}\text { помещения на основании договоров } \\
\text { купли-продажи - всего, тыс. }\end{array}\end{array}$ & 2443 & 3203 & 3286 & 3302 & 3220 \\
$\quad \begin{array}{l}\text { в том числе гражданам Российской } \\
\text { Федерации }\end{array}$ & 2389 & 3120 & 3203 & 3223 & 3152 \\
$\begin{array}{l}\text { Общая площадь жилых помещений, на которые } \\
\text { зарегистрированы права на основании }\end{array}$ & & & & & \\
договоров купли-продажи, тыс. м² \\
$\begin{array}{l}\text { в том числе гражданам Российской } \\
\text { Федерации }\end{array}$
\end{tabular}

4.19. ЖИЛИЩНЫЕ КРЕДИТЫ, ПРЕДОСТАВЛЕННЫЕ КРЕДИТНЫМИ ОРГАНИЗАЦИЯМИ ФИЗИЧЕСКИМ ЛИЦАМ ${ }^{1)}$

(за год)

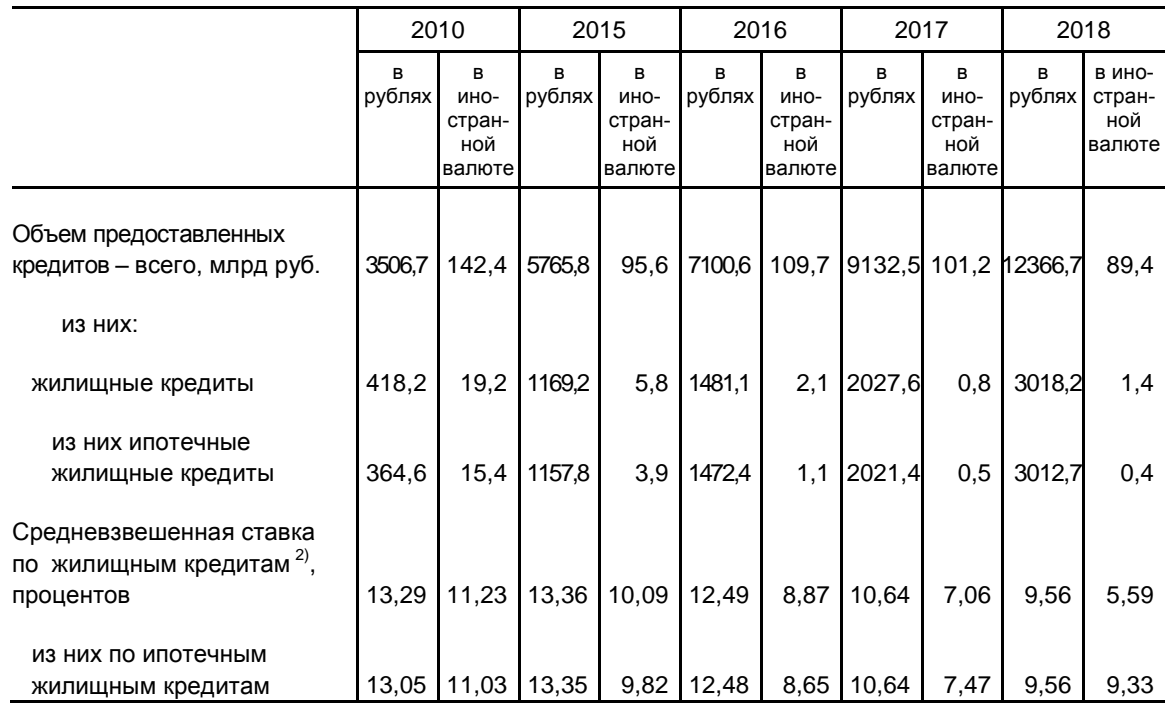

\footnotetext{
1) По данным Банка России.

2) По кредитам, выданным с начала года.
} 


\section{5. ИНВЕСТИЦИИ И ФИНАНСОВОЕ СОСТОЯНИЕ ЖИЛИЩНО-КОММУНАЛЬНОГО ХОЗЯЙСТВА}

\section{ИНВЕСТИЦИИ В ЖИЛИЩНО-КОММУНАЛЬНОЕ ХОЗЯЙСТВО}

\section{1. ИНВЕСТИЦИИ В ЖИЛЫЕ ЗДАНИЯ И ПОМЕЩЕНИЯ}

(в фактически действовавших ценах)

\begin{tabular}{l|r|r}
\hline & 2017 & 2018 \\
\hline Всего, млн руб. & 2177884 & 2237167 \\
в процентах от общего объема инвестиций в основной капитал & 13,6 & 12,7 \\
\hline
\end{tabular}

\section{2. ИНВЕСТИЦИИ В ОСНОВНОЙ КАПИТАЛ, НАПРАВЛЕННЫЕ}

НА РАЗВИТИЕ ВИДОВ ЭКОНОМИЧЕСКОЙ ДЕЯТЕЛЬНОСТИ, ОТНОСЯЩИХСЯ К КОММУНАЛЬНОМУ ХОЗЯЙСТВУ')

(в фактически действовавших ценах; миллионов рублей)

\begin{tabular}{|c|c|c|}
\hline & 2017 & 2018 \\
\hline $\begin{array}{l}\text { Распределение газообразного топлива по газораспределительным } \\
\text { сетям }\end{array}$ & 77755,3 & 93591,2 \\
\hline Распределение пара и горячей воды (тепловой энергии) & 8631,3 & 7740,6 \\
\hline Распределение воды для питьевых и промышленных нужд & 41333,4 & 45262,7 \\
\hline Сбор и обработка сточных вод & 40120,3 & 41705,9 \\
\hline Распределение электроэнергии & 28273,9 & 24310,6 \\
\hline
\end{tabular}

1) Без субъектов малого предпринимательства и объема инвестиций, не наблюдаемых прямыми статистическими методами.

\section{3. ИНДЕКСЫ ФИЗИЧЕСКОГО ОБЪЕМА ИНВЕСТИЦИЙ В ОСНОВНОЙ} КАПИТАЛ, НАПРАВЛЕННЫЕ НА РАЗВИТИЕ ВИДОВ ЭКОНОМИЧЕСКОЙ ДЕЯТЕЛЬНОСТИ, ОТНОСЯЩИХСЯ К КОММУНАЛЬНОМУ ХОЗЯЙСТВУ')

(в сопоставимых ценах; в процентах к предыдущему году)

\begin{tabular}{|c|c|c|}
\hline & 2017 & 2018 \\
\hline $\begin{array}{l}\text { Распределение газообразного топлива по газораспределительным } \\
\text { сетям }\end{array}$ & 117,1 & 116,4 \\
\hline Распределение пара и горячей воды (тепловой энергии) & 101,3 & 86,7 \\
\hline Распределение воды для питьевых и промышленных нужд & 77,4 & 106,0 \\
\hline Сбор и обработка сточных вод & 95,2 & 99,2 \\
\hline Распределение электроэнергии & 95,7 & 83,2 \\
\hline
\end{tabular}

1) Без субъектов малого предпринимательства и объема инвестиций, не наблюдаемых прямыми статистическими методами. 


\title{
ФИНАНСОВОЕ СОСТОЯНИЕ ОРГАНИЗАЦИЙ ЖИЛИЩНО-КОММУНАЛЬНОГО ХОЗЯЙСТВА
}

\author{
5.4. ОСНОВНЫЕ ФИНАНСОВЫЕ ПОКАЗАТЕЛИ РАБОТЫ \\ ОРГАНИЗАЦИЙ ПО ВИДУ ЭКОНОМИЧЕСКОЙ ДЕЯТЕЛЬНОСТИ \\ «УПРАВЛЕНИЕ ЭКСПЛУАТАЦИЕЙ ЖИЛОГО ФОНДА» в 2010 - 2016 гг. 1); 2)
}

\begin{tabular}{|c|c|c|c|}
\hline & 2010 & 2015 & 2016 \\
\hline $\begin{array}{l}\text { Сальдированный финансовый результат } \\
\text { (прибыль минус убыток), млн руб. }\end{array}$ & -2567 & -4249 & -2429 \\
\hline Сумма прибыли, млн руб. & 6008 & 9969 & 8825 \\
\hline $\begin{array}{l}\text { Удельный вес прибыльных организаций } \\
\text { в общем числе организаций, процентов }\end{array}$ & 57,6 & 72,0 & 72,1 \\
\hline Сумма убытка, млн руб. & 8575 & 14218 & 11254 \\
\hline $\begin{array}{l}\text { Удельный вес убыточных организаций } \\
\text { в общем числе организаций, процентов }\end{array}$ & 42,4 & 28,0 & 27,9 \\
\hline $\begin{array}{l}\text { Рентабельность проданных товаров, продукции } \\
(\text { работ, услуг) })^{3} \text {, процентов }\end{array}$ & $-5,3$ & 1,2 & $-0,4$ \\
\hline Рентабельность активов ${ }^{3)}$, процентов & $-1,0$ & $-1,1$ & $-0,9$ \\
\hline Коэффициент автономии (на конец года), процентов & 43,4 & 39,4 & 19,7 \\
\hline $\begin{array}{l}\text { Коэфффициент обеспеченности собственными } \\
\text { оборотными средствами (на конец года), процентов }\end{array}$ & 4,9 & 16,3 & $-14,1$ \\
\hline $\begin{array}{l}\text { Коэффиициент текущей ликвидности (на конец года), } \\
\text { процентов }\end{array}$ & 111,8 & 138,3 & 103,3 \\
\hline
\end{tabular}

1) В соответствии с Общероссийским классификатором видов экономической деятельности ОК 029-2007 (ОКВЭД-2007).

2) Без субъектов малого предпринимательства. По данным бухгалтерской отчетности.

3) Знак (-) означает убыточность.

\section{5. ОСНОВНЫЕ ФИНАНСОВЫЕ ПОКАЗАТЕЛИ РАБОТЫ ОРГАНИЗАЦИЙ ПО ВИДУ ЭКОНОМИЧЕСКОЙ ДЕЯТЕЛЬНОСТИ «УПРАВЛЕНИЕ ЭКСПЛУАТАЦИЕЙ ЖИЛОГО ФОНДА ЗА ВОЗНАГРАЖДЕНИЕ ИЛИ НА ДОГОВОРНОЙ ОСНОВЕ»);}

\begin{tabular}{|c|c|c|}
\hline & 2017 & 2018 \\
\hline $\begin{array}{l}\text { Сальдированный финанссовый результат } \\
\text { (прибыль минус убыток), млн руб. }\end{array}$ & -1787 & -3357 \\
\hline Сумма прибыли, млн руб. & 9551 & 7780 \\
\hline $\begin{array}{l}\text { Удельный вес прибыльных организаций } \\
\text { в общем числе организаций, процентов }\end{array}$ & 71,4 & 70,4 \\
\hline Сумма убытка, млн руб. & 11338 & 11137 \\
\hline $\begin{array}{l}\text { Удельный вес убыточных организаций } \\
\text { в общем числе организаций, процентов }\end{array}$ & 28,6 & 29,6 \\
\hline $\begin{array}{l}\text { Рентабельность проданных товаров, продукции } \\
(\text { (работ, услуг) })^{3)} \text {, процентов }\end{array}$ & 0,5 & $-0,1$ \\
\hline Рентабельность активов ${ }^{3)}$, процентов & $-0,6$ & $-1,0$ \\
\hline Коэфффициент автономии (на конец года), процентов & 12,9 & 7,0 \\
\hline $\begin{array}{l}\text { Коэфффициент обеспеченности собственными } \\
\text { оборотными средствами (на конец года), процентов }\end{array}$ & $-11,1$ & $-19,0$ \\
\hline $\begin{array}{l}\text { Коэфффициент текущей ликвидности (на конец года), } \\
\text { процентов }\end{array}$ & 108,0 & 103,5 \\
\hline
\end{tabular}

\footnotetext{
1) В соответствии с Общероссийским классификатором видов экономической деятельности ОК 029-2014 (ОКВЭД-2).

2) Без субъектов малого предпринимательства. По данным бухгалтерской отчетности.

3) Знак (-) означает убыточность.
} 


\section{8. СТРУКТУРА СУММАРНОЙ ЗАДОЛЖЕННОСТИ \\ ОРГАНИЗАЦИЙ ПО ВИДУ ЭКОНОМИЧЕСКОЙ ДЕЯТЕЛЬНОСТИ «УПРАВЛЕНИЕ ЭКСПЛУАТАЦИЕЙ ЖИЛОГО ФОНДА» В 2010 - 2016 гг. ${ }^{1)}$}

(в процентах к итогу)

\begin{tabular}{|c|c|c|c|}
\hline & 2010 & 2015 & 2016 \\
\hline $\begin{array}{l}\text { Суммарная задолженность по обязательствам - всего } \\
\text { в том числе: }\end{array}$ & 100 & 100 & 100 \\
\hline кредиторская задолженность & 88,8 & 93,6 & 79,8 \\
\hline задолженность по кредитам банков и полученным займам & 11,2 & 6,4 & 20,2 \\
\hline $\begin{array}{l}\text { Просроченная суммарная задолженность по обязательствам - } \\
\text { всего }\end{array}$ & 100 & 100 & 100 \\
\hline в том числе: & & & \\
\hline кредиторская задолженность & 96,3 & 99,4 & 99,6 \\
\hline задолженность по кредитам банков и полученным займам & 3,7 & 0,6 & 0,4 \\
\hline
\end{tabular}

${ }^{1)}$ В соответствии с Общероссийским классификатором видов экономической деятельности ОК 029-2007 (ОКВЭД-2007).

\section{9. СТРУКТУРА СУММАРНОЙ ЗАДОЛЖЕННОСТИ ОРГАНИЗАЦИЙ ПО ВИДУ ЭКОНОМИЧЕСКОЙ ДЕЯТЕЛЬНОСТИ «УПРАВЛЕНИЕ ЭКСПЛУАТАЦИЕЙ ЖИЛОГО ФОНДА ЗА ВОЗНАГРАЖДЕНИЕ ИЛИ НА ДОГОВОРНОЙ ОСНОВЕ»}

(в процентах к итогу)

\begin{tabular}{|c|c|c|}
\hline & 2017 & 2018 \\
\hline $\begin{array}{l}\text { Суммарная задолженность по обязательствам - всего } \\
\text { в том числе: }\end{array}$ & 100 & 100 \\
\hline кредиторская задолженность & 94,1 & 94,1 \\
\hline задолженность по кредитам банков и полученным займам & 5,9 & 5,9 \\
\hline $\begin{array}{l}\text { Просроченная суммарная задолженность по обязательствам - } \\
\text { всего }\end{array}$ & 100 & 100 \\
\hline \multicolumn{3}{|l|}{ в том числе: } \\
\hline кредиторская задолженность & 99,3 & 99,5 \\
\hline задолженность по кредитам банков и полученным займам & 0,7 & 0,5 \\
\hline
\end{tabular}

\footnotetext{
${ }^{1)}$ В соответствии с Общероссийским классификатором видов экономической деятельности ОК 029-2014 (ОКВЭД-2).
} 


\subsection{0. СТРУКТУРА КРЕДИТОРСКОЙ ЗАДОЛЖЕННОСТИ ОРГАНИЗАЦИЙ ПО ВИДУ ЭКОНОМИЧЕСКОЙ ДЕЯТЕЛЬНОСТИ «УПРАВЛЕНИЕ ЭКСПЛУАТАЦИЕЙ ЖИЛОГО ФОНДА» В 2010 - 2016 гг. ${ }^{1)}$}

(в процентах к итогу)

\begin{tabular}{l|r|r|r}
\hline & 2010 & 2015 & 2016 \\
\hline Кредиторская задолженность & 100 & 100 & 100 \\
$\quad$ из нее задолженность: & & & \\
поставщикам & 70,4 & 79,8 & 61,7 \\
по платежам в бюджет & 6,7 & 4,2 & 3,0 \\
в государственные внебюджетные фронды & 2,2 & 2,0 & 1,6 \\
Просроченная кредиторская задолженность & 100 & 100 & 100 \\
из нее задолженность: & & & \\
поставщикам & 76,7 & 82,0 & 90,1 \\
по платежам в бюджет & 9,1 & 3,1 & 3,3 \\
в государственные внебюджетные фонды & 4,8 & 2,1 & 2,7 \\
\hline
\end{tabular}

${ }^{1)}$ В соответствии с Общероссийским классификатором видов экономической деятельности ОК 029-2007 (ОКВЭД-2007).

\subsection{1. СТРУКТУРА КРЕДИТОРСКОЙ ЗАДОЛЖЕННОСТИ ОРГАНИЗАЦИЙ ПО ВИДУ ЭКОНОМИЧЕСКОЙ ДЕЯТЕЛЬНОСТИ «УПРАВЛЕНИЕ ЭКСПЛУАТАЦИЕЙ ЖИЛОГО ФОНДА ЗА ВОЗНАГРАЖДЕНИЕ ИЛИ НА ДОГОВОРНОЙ ОСНОВЕ»}

(в процентах к итогу)

\begin{tabular}{l|c|c}
\hline & 2017 & 2018 \\
\hline Кредиторская задолженность & 100 & 100 \\
из нее задолженность: & & 75,4 \\
поставщикам & 77,8 & 3,5 \\
по платежам в бюджет & 4,0 & 1,5 \\
в государственные внебюджетные фронды & 1,8 & 100 \\
Просроченная кредиторская задолженность & 100 & \\
из нее задолженность: & & 92,6 \\
поставщикам & 90,7 & 2,8 \\
по платежам в бюджет & 3,4 & 1,9 \\
в государственные внебюджетные фонды & 2,6 & \\
\hline
\end{tabular}

1) В соответствии с Общероссийским классификатором видов экономической деятельности ОК 029-2014 (ОКВЭД-2). 


\subsection{2. СТРУКТУРА ДЕБИТОРСКОЙ ЗАДОЛЖЕННОСТИ ОРГАНИЗАЦИЙ ПО ВИДУ ЭКОНОМИЧЕСКОЙ ДЕЯТЕЛЬНОСТИ «УПРАВЛЕНИЕ ЭКСПЛУАТАЦИЕЙ ЖИЛОГО ФОНДА» В 2010 - 2016 гг. ${ }^{1)}$}

(в процентах к итогу)

\begin{tabular}{|c|c|c|c|}
\hline & 2010 & 2015 & 2016 \\
\hline Дебиторская задолженность & 100 & 100 & 100 \\
\hline $\begin{array}{l}\text { из нее задолженность покупателей } \\
\text { из нее: }\end{array}$ & 68,9 & 83,2 & 77,6 \\
\hline $\begin{array}{l}\text { задолженность по полученным векселям } \\
\text { задолженность государственных заказчиков } \\
\text { по оплате за поставленную продукцию }\end{array}$ & $\begin{array}{l}0,0 \\
0,0\end{array}$ & 0,0 & $\begin{array}{l}0,0 \\
0,0\end{array}$ \\
\hline Просроченная дебиторская задолженность & 100 & 100 & 100 \\
\hline $\begin{array}{l}\text { из нее задолженность покупателей } \\
\text { из нее: }\end{array}$ & 83,9 & 91,4 & 92,8 \\
\hline $\begin{array}{l}\text { задолженность по полученным векселям } \\
\text { задолженность государственных заказчиков } \\
\text { по оплате за поставленную продукцию }\end{array}$ & $\begin{array}{l}0,0 \\
0,0\end{array}$ & 0,1 & $\begin{array}{r}- \\
0,1\end{array}$ \\
\hline
\end{tabular}

1) В соответствии с Общероссийским классификатором видов экономической деятельности ОК 029-2007(ОКВЭД-2007).

\subsection{3. СТРУКТУРА ДЕБИТОРСКОЙ ЗАДОЛЖЕННОСТИ ОРГАНИЗАЦИЙ ПО ВИДУ ЭКОНОМИЧЕСКОЙ ДЕЯТЕЛЬНОСТИ «УПРАВЛЕНИЕ ЭКСПЛУАТАЦИЕЙ ЖИЛОГО ФОНДА ЗА ВОЗНАГРАЖДЕНИЕ ИЛИ НА ДОГОВОРНОЙ ОСНОВЕ» ${ }^{1)}$}

(в процентах к итогу)

\begin{tabular}{|c|c|c|}
\hline & 2017 & 2018 \\
\hline Дебиторская задолженность & 100 & 100 \\
\hline из нее задолженность покупателей & 85,1 & 81,0 \\
\hline \multicolumn{3}{|l|}{ из нее: } \\
\hline задолженность по полученным векселям & 0,0 & 0,0 \\
\hline задолженность государственных заказчиков & & \\
\hline по оплате за поставленную продукцию & 0,0 & 0,0 \\
\hline Просроченная дебиторская задолженность & 100 & 100 \\
\hline из нее задолженность покупателей & 96,4 & 96,2 \\
\hline \multicolumn{3}{|l|}{ из нее: } \\
\hline задолженность по полученным векселям & - & 0,0 \\
\hline задолженность государственных заказчиков & & \\
\hline по оплате за поставленную продукцию & 0,0 & 0,0 \\
\hline
\end{tabular}

\footnotetext{
1) В соответствии с Общероссийским классификатором видов экономической деятельности ОК 029-2014 (ОКВЭД-2).
} 


\subsection{4. ФИНАНСОВЫЕ ВЛОЖЕНИЯ ОРГАНИЗАЦИЙ \\ ПО ВИДУ ЭКОНОМИЧЕСКОЙ ДЕЯТЕЛЬНОСТИ \\ «УПРАВЛЕНИЕ ЭКСПЛУАТАЦИЕЙ ЖИЛОГО ФОНДА» \\ B $2010-2016$ (r. ${ }^{1)}$}

\begin{tabular}{|c|c|c|c|}
\hline & 2010 & 2015 & 2016 \\
\hline Финансовые вложения - всего, тыс. руб. & 10069804 & 37144228 & 40159545 \\
\hline \multicolumn{4}{|l|}{ в том числе: } \\
\hline долгосрочные & 928629 & 699895 & 334307 \\
\hline в процентах к общему объему финансовых вложений & 9,2 & 1,9 & 0,8 \\
\hline краткосрочные & 9141175 & 36444333 & 39825238 \\
\hline в процентах к общему объему финансовых вложений & 90,8 & 98,1 & 99,2 \\
\hline
\end{tabular}

1) В соответствии с Общероссийским классификатором видов экономической деятельности ОК 029-2007 (ОКВЭД-2007).

\subsection{5. ФИНАНСОВЫЕ ВЛОЖЕНИЯ ОРГАНИЗАЦИЙ ПО ВИДУ ЭКОНОМИЧЕСКОЙ ДЕЯТЕЛЬНОСТИ «УПРАВЛЕНИЕ ЭКСПЛУАТАЦИЕЙ ЖИЛОГО ФОНДА ЗА ВОЗНАГРАЖДЕНИЕ ИЛИ НА ДОГОВОРНОЙ ОСНОВЕ»")}

\begin{tabular}{|c|c|c|}
\hline & 2017 & 2018 \\
\hline Финансовые вложения - всего, тыс. руб. & 54790198 & 78600736 \\
\hline \multicolumn{3}{|l|}{ в том числе: } \\
\hline долгосрочные & 227799 & 3789254 \\
\hline в процентах к общему объему финансовых вложений & 0,4 & 4,8 \\
\hline краткосрочные & 54562399 & 74811482 \\
\hline в процентах к общему объему финансовых вложений & 99,6 & 95,2 \\
\hline
\end{tabular}

\footnotetext{
1) В соответствии с Общероссийским классификатором видов экономической деятельности ОК 029-2014 (ОКВЭД-2).
} 


\section{6. РЕАЛИЗАЦИЯ ПРОГРАММ В СФЕРЕ ЖИЛИЩНО-КОММУНАЛЬНОГО ХОЗЯЙСТВА}

\section{1. ОСНОВНЫЕ ПОКАЗАТЕЛИ ГОСУДАРСТВЕННОЙ ПРОГРАММЫ «ОБЕСПЕЧЕНИЕ ДОСТУПНЫМ И КОМФОРТНЫМ ЖИЛЬЕМ И КОММУНАЛЬНЫМИ УСЛУГАМИ ГРАЖДАН РОССИЙСКОЙ ФЕДЕРАЦИИ ${ }^{1)}$}

(на конец года)

\begin{tabular}{l|r|r|r|r}
\hline & 2015 & 2016 & 2017 & 2018 \\
\hline $\begin{array}{l}\text { Коэффициент доступности жилья (соотношение средней } \\
\text { рыночной стоимости стандартного жилого помещения общей } \\
\text { площадью 54 м² и среднего годового денежного дохода семьи, } \\
\text { состоящей из 3 человек) }\end{array}$ & 2,7 & 2,6 & 2,6 & 2,7 \\
Количество выданных ипотечных кредитов ${ }^{2)}$, единиц & 699419 & 856521 & 1086940 & 1471809 \\
$\begin{array}{l}\text { Количество семей граждан, категории которых установлены } \\
\text { федеральным законодательством, улучшивших жилищные } \\
\text { условия, тыс. человек }\end{array}$ & 22,7 & 18,7 & 14,1 & 11,8 \\
$\begin{array}{l}\text { Численность граждан, переселенных из аварийного жилищного } \\
\text { фонда, тыс. человек }\end{array}$ & 161,4 & 169,7 & 179,1 & 72,4 \\
\hline
\end{tabular}

1) По данным Минстроя России.

2) По данным Банка России.

6.2. ОБЩАЯ ПЛОЩАДЬ КАПИТАЛЬНО ОТРЕМОНТИРОВАННЫХ
МНОГОКВАРТИРНЫХ ЖИЛЫХ ДОМОВ И ОБЩИЕ ЗАТРАТЫ
НА КАПИТАЛЬНЫЙ РЕМОНТ МНОГОКВАРТИРНЫХ ЖИЛЫХ ДОМОВ

\begin{tabular}{|c|c|c|c|c|c|}
\hline & 2010 & 2015 & 2016 & 2017 & 2018 \\
\hline $\begin{array}{l}\text { Общая площадь капитально отремонтированных } \\
\text { многоквартирных жилых домов - всего, тыс. м² } \\
\text { в том числе: }\end{array}$ & 29428,3 & 28280,9 & 16018,2 & 39501,5 & 33005,8 \\
\hline в городских поселениях & 27756,4 & 26951,0 & 15389,4 & 39072,8 & 32549,1 \\
\hline в сельских поселениях & 1672,0 & 1329,9 & 628,8 & 428,7 & 456,7 \\
\hline $\begin{array}{l}\text { Удельный вес общей площади капитально } \\
\text { отремонтированных жилых многоквартирных } \\
\text { домов от общей площади жилых помещений } \\
\text { многоквартирных жилых домов, процентов }\end{array}$ & 1,4 & 1,2 & 0,7 & 1,6 & 1,3 \\
\hline $\begin{array}{l}\text { Общие затраты на капитальный ремонт } \\
\text { многоквартирных жилых домов - всего, млн руб. } \\
\text { в том числе: }\end{array}$ & 107821,4 & 71712,7 & 128775,8 & 162100,3 & 190954,7 \\
\hline в городских поселениях & 98668,7 & 66558,0 & 119337,7 & 153808,4 & 176121,4 \\
\hline в сельских поселениях & 9152,7 & 5154,7 & 9438,1 & 8291,9 & 14833,4 \\
\hline
\end{tabular}




\section{3. ЧИСЛО МНОГОКВАРТИРНЫХ ЖИЛЫХ ДОМОВ, В КОТОРЫХ} ПРОВЕДЕН КАПИТАЛЬНЫЙ РЕМОНТ И ТРЕБУЮЩИХ КАПИТАЛЬНОГО РЕМОНТА

\begin{tabular}{|c|c|c|c|c|c|}
\hline & 2010 & 2015 & 2016 & 2017 & 2018 \\
\hline $\begin{array}{l}\text { Число многоквартирных жилых домов, } \\
\text { в которых проведен капитальный ремонт } \\
\text { за год } \\
\text { Число многоквартирных жилых домов, } \\
\text { требующих капитального ремонта } \\
\text { на конец года }\end{array}$ & $\begin{array}{r}54028 \\
282157\end{array}$ & $\begin{array}{r}25414 \\
272910\end{array}$ & $\begin{array}{r}36771 \\
157526 \\
\end{array}$ & $\begin{array}{r}39533 \\
150576 \\
\end{array}$ & $\begin{array}{r}43120 \\
139978 \\
\end{array}$ \\
\hline
\end{tabular}

\section{4. УЛУЧШЕНИЕ ЖИЛИЩНЫХ УСЛОВИЙ ПО ОТДЕЛЬНЫМ КАТЕГОРИЯМ ГРАЖДАН}

\begin{tabular}{|c|c|c|c|c|c|}
\hline & 2010 & 2015 & 2016 & 2017 & 2018 \\
\hline $\begin{array}{l}\text { Число семей, состоящих на учете в каче- } \\
\text { стве нуждающихся в жилых помещениях } \\
\text { (на конец года), тыс. }\end{array}$ & 2821,4 & 2612,4 & 2542,4 & 2458,3 & 2364,4 \\
\hline $\begin{array}{l}\text { В том числе: } \\
\text { семьи участников Великой Отечественной } \\
\text { войны }\end{array}$ & 10,1 & 2,0 & 1,2 & 0,8 & 0,8 \\
\hline многодетные семьи & 114,4 & 131,2 & 129,2 & 131,6 & 132,6 \\
\hline молодые семьи & 408,5 & 416,4 & 387,7 & 357,8 & 331,6 \\
\hline $\begin{array}{l}\text { семьи, проживающие в ветхом } \\
\text { и аварийном жилищном фонде }{ }^{2)}\end{array}$ & 245,6 & 177,0 & 167,1 & 140,8 & 120,9 \\
\hline $\begin{array}{l}\text { Число семей, получивших жилые } \\
\text { помещения и улучшивших жилищные } \\
\text { условия за год, тыс. }\end{array}$ & 243,9 & 134.9 & 128.6 & & \\
\hline $\begin{array}{l}\text { в том числе: } \\
\text { семьи участников Великой Отечественной } \\
\text { войны }\end{array}$ & 26,7 & 134,9 & 128,6 & 122,6 & 99,2 \\
\hline многодетные семьи & 4,5 & 5,5 & 6,0 & 5,0 & 4,4 \\
\hline молодые семьи ${ }^{1)}$ & 29,2 & 23,8 & 22,8 & 22,0 & 22,8 \\
\hline $\begin{array}{l}\text { семьи, проживающие в ветхом } \\
\text { и аварийном жилищном фонде } \mathrm{e}^{2)}\end{array}$ & 22,4 & 21,8 & 20,3 & 19,2 & 9,4 \\
\hline $\begin{array}{l}\text { Дети-сироты и дети, оставшиеся без } \\
\text { попечения родителей, лица из числа } \\
\text { детей-сирот и детей, оставшихся без } \\
\text { попечения родителей, получившие жилое } \\
\text { помещение, тыс. }\end{array}$ & $\ldots$ & $\ldots$ & $\ldots$ & 23,1 & 22,9 \\
\hline $\begin{array}{l}\text { Число семей, получивших жилые помеще- } \\
\text { ния и улучшивших жилищные условия, } \\
\text { в процентах от числа семей, состоящих } \\
\text { на учете в качестве нуждающихся в жилых } \\
\text { помещениях (к началу соответствующего } \\
\text { года) }\end{array}$ & 8,6 & 5,0 & 4,9 & 4,8 & 4,0 \\
\hline в том числе: & & & & & \\
\hline $\begin{array}{l}\text { семьи участников Великой Отечественной } \\
\text { войны }\end{array}$ & 174,3 & 48,5 & 51,9 & 36,3 & 27,6 \\
\hline многодетные семьи & 3,6 & 4,4 & 4,6 & 3,9 & 3,3 \\
\hline молодые семьи & 7,3 & 5,4 & 5,5 & 5,7 & 6,4 \\
\hline $\begin{array}{l}\text { семьи, проживающие в ветхом и аварий- } \\
\text { ном жилищном фонде }{ }^{2)}\end{array}$ & 8,3 & 11,3 & 11,5 & 11,5 & 6,6 \\
\hline
\end{tabular}

\footnotetext{
1) Молодая семья - возраст каждого из супругов либо одного родителя в неполной семье не превышает 35 лет.

2) 2018 г. - данные приведены по семьям, проживающим в аварийном жилищном фонде.
} 


\section{5. УЛУЧШЕНИЕ ЖИЛИЩНЫХ УСЛОВИЙ УЧАСТНИКОВ ВЕЛИКОЙ ОТЕЧЕСТВЕННОЙ ВОЙНЫ}

(семей)

\begin{tabular}{|c|c|c|c|c|c|c|c|c|c|c|}
\hline & \multicolumn{5}{|c|}{$\begin{array}{c}\text { Число семей, состоящих на учете } \\
\text { в качестве нуждающихся в жилых } \\
\text { помещениях (на конец года) }\end{array}$} & \multicolumn{5}{|c|}{$\begin{array}{c}\text { Число семей, получивших жилые } \\
\text { помещения и улучшивших жилищные } \\
\text { условия за год }\end{array}$} \\
\hline & 2010 & 2015 & 2016 & 2017 & 2018 & 2010 & 2015 & 2016 & 2017 & 2018 \\
\hline Семьи участников Великой & & & & & & & & & & \\
\hline $\begin{array}{l}\text { Отечественной войны } \\
\text { из них одиноких } \\
\text { участников Великой } \\
\text { Отечественной войны, } \\
\text { проживающих }\end{array}$ & 10086 & 2004 & 1196 & 845 & 768 & 26708 & 1536 & 1040 & 434 & 233 \\
\hline $\begin{array}{l}\text { в коммунальных квартирах } \\
\text { Семьи погибших (умерших) } \\
\text { инвалидов войны, } \\
\text { участников Великой } \\
\text { Отечественной войны } \\
\text { и ветеранов боевых }\end{array}$ & 219 & 40 & 17 & 13 & 2 & 943 & 52 & 15 & 8 & 4 \\
\hline $\begin{array}{l}\text { действий } \\
\text { Семьи военнослужащих, } \\
\text { проходивших военную } \\
\text { службу в воинских частях, } \\
\text { учреждениях, военно- } \\
\text { учебных заведениях, } \\
\text { не входивших в состав } \\
\text { действующей армии, } \\
\text { в период с } 22.06 .1941 \\
\text { по 3.09.1945 гг. не менее } \\
\text { шести месяцев; военно- } \\
\text { служащих, награжденных } \\
\text { орденами или медалями } \\
\text { сссР за службу в указан- }\end{array}$ & 31279 & 9591 & 6016 & 4255 & 3539 & 55487 & 6241 & 4882 & 2399 & 1066 \\
\hline ный период & 393 & 180 & 110 & 117 & 114 & 251 & 19 & 12 & 12 & 5 \\
\hline
\end{tabular}




\section{РЕФОРМА ЖИЛИЩНО-КОММУНАЛЬНОГО ХОЗЯЙСТВА}

\section{6. ОПЛАТА НАСЕЛЕНИЕМ ЖИЛИЩНО-КОММУНАЛЬНЫХ УСЛУГ}

(миллиардов рублей)

\begin{tabular}{|c|c|c|c|c|c|}
\hline & 2010 & 2015 & 2016 & 2017 & 2018 \\
\hline $\begin{array}{l}\text { Начислено жилищно-коммунальных } \\
\text { платежей населению } \\
\text { в том числе: }\end{array}$ & 1384,3 & 2126,6 & 2337,4 & 2501,1 & 2632,7 \\
\hline жилищных платежей & 297,2 & 550,5 & 646,8 & 724,2 & 761,0 \\
\hline $\begin{array}{l}\text { коммунальных платежей } \\
\text { из них: }\end{array}$ & 1087,0 & 1576,1 & 1690,5 & 1777,0 & 1871,7 \\
\hline водоснабжение & 107,0 & 134,0 & 143,0 & 150,4 & 158,6 \\
\hline водоотведение (канализация) & 84,9 & 100,5 & 106,9 & 112,6 & 120,4 \\
\hline электроснабжение & 229,7 & 387,2 & 413,5 & 441,9 & 466,0 \\
\hline отопление & 375,1 & 541,8 & 596,3 & 619,5 & 650,1 \\
\hline горячее водоснабжение & 141,5 & 170,2 & 174,7 & 182,9 & 192,7 \\
\hline газ сетевой & 135,3 & 228,8 & 243,4 & 255,4 & 262,4 \\
\hline $\begin{array}{l}\text { Фактически оплачено населением } \\
\text { жилищно-коммунальных платежей } \\
\text { в том числе: }\end{array}$ & 1289,1 & 1990,8 & 2190,4 & 2392,5 & 2511,4 \\
\hline жилищных платежей & 278,3 & 497,8 & 596,9 & 677,0 & 718,3 \\
\hline $\begin{array}{l}\text { коммунальных платежей } \\
\text { из них: }\end{array}$ & 1010,8 & 1493,0 & 1593,5 & 1715,5 & 1793,2 \\
\hline водоснабжение & 99,1 & 124,3 & 134,0 & 141,7 & 150,9 \\
\hline водоотведение (канализация) & 78,2 & 93,2 & 100,1 & 106,6 & 113,0 \\
\hline электроснабжение & 219,7 & 375,6 & 400,5 & 432,3 & 453,5 \\
\hline отопление & 343,6 & 506,9 & 552,9 & 597,4 & 617,8 \\
\hline горячее водоснабжение & 127,3 & 160,9 & 161,7 & 174,3 & 181,8 \\
\hline $\begin{array}{l}\quad \text { газ сетевой } \\
\text { Фактический уровень платежей насел } \\
\text { за жилое помещение и коммунальные } \\
\text { услуги }{ }^{1)} \text {, процентов }\end{array}$ & 129,8 & 219,0 & 231,8 & 249,1 & 256,4 \\
\hline
\end{tabular}

1) С учетом восполнения задолженности. 


\section{6. РАСХОДЫ КОНСОЛИДИРОВАННОГО БЮДЖЕТА РОССИЙСКОЙ ФЕДЕРАЦИИ НА ЖИЛИЩНО-КОММУНАЛЬНОЕ ХОЗЯЙСТВО ${ }^{1)}$}

\begin{tabular}{c|c|c|c}
\hline \multirow{2}{*}{ Годы } & \multirow{2}{*}{$\begin{array}{c}\text { Всего, } \\
\text { млрд руб. }\end{array}$} & $\begin{array}{c}\mid c \\
\text { Вт общего объема } \\
\text { расходов }\end{array}$ & к ВВП \\
\cline { 3 - 4 } 2010 & 1071,4 & 6,1 & 2,3 \\
2015 & 979,9 & 3,3 & 1,2 \\
2016 & 992,6 & 3,2 & 1,2 \\
2017 & 1209,9 & 3,7 & 1,3 \\
2018 & 1324,1 & 3,9 & 1,3 \\
\hline
\end{tabular}

1) По данным Федерального казначейства.

5.7. ЗАДОЛЖЕННОСТЬ ПО ФИНАНСОВЫМ ОБЯЗАТЕЛЬСТВАМ ОРГАНИЗАЦИЙ, ОСУЩЕСТВЛЯЮЩИХ ДЕЯТЕЛЬНОСТЬ ПО УПРАВЛЕНИЮ ЭКСПЛУАТАЦИЕЙ ЖИЛОГО ФОНДА

(миллионов рублей)

\begin{tabular}{|c|c|c|c|c|c|}
\hline & 2010 & 2015 & 2016 & 2017 & 2018 \\
\hline Суммарная задолженность по обязательствам & 127733 & 145699 & 234119 & 136541 & 148964 \\
\hline в том числе просроченная & 21807 & 22721 & 21647 & 19139 & 19627 \\
\hline \multicolumn{6}{|l|}{ Из суммарной задолженности: } \\
\hline кредиторская задолженность & 113390 & 136322 & 186944 & 128419 & 140132 \\
\hline в том числе просроченная & 20990 & 22592 & 21561 & 19005 & 19529 \\
\hline $\begin{array}{l}\text { задолженность по кредитам банков } \\
\text { и полученным займам }\end{array}$ & 14343 & 9377 & 47175 & 8122 & 8832 \\
\hline в том числе просроченная & 817 & 129 & 86 & 134 & 98 \\
\hline дебиторская задолженность & 108458 & 119369 & 127414 & 114593 & 121792 \\
\hline в том числе просроченная & 18101 & 20190 & 19684 & 21687 & 22693 \\
\hline
\end{tabular}




\section{7. СТРУКТУРА КОММУНАЛЬНЫХ ПЛАТЕЖЕЙ НАСЕЛЕНИЯ В 2018 Г.}

(в процентах)

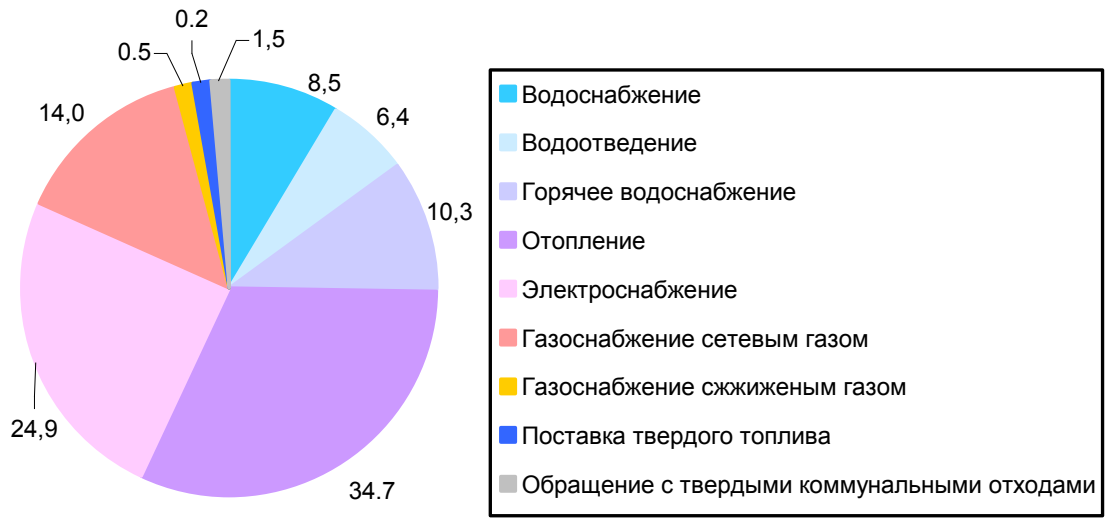

\section{8. УДЕЛЬНЫЙ ВЕС РАСХОДОВ НА ОПЛАТУ ЖИЛИЩНО-КОММУНАЛЬНЫХ УСЛУГ В ПОТРЕБИТЕЛЬСКИХ РАСХОДАХ ДОМАШНИХ ХОЗЯЙСТВ}

(по итогам выборочного обследования бюджетов домашних хозяйств; в процентах от общей суммы потребительских расходов)

\begin{tabular}{|c|c|c|c|c|c|}
\hline & 2010 & 2015 & 2016 & 2017 & 2018 \\
\hline & \multicolumn{5}{|c|}{ Все домашние хозяйства } \\
\hline \multirow{2}{*}{\multicolumn{6}{|c|}{$\begin{array}{l}\text { Расходы на оплату жилищно-коммунальных } \\
\text { услуг - всего }\end{array}$}} \\
\hline & 9,2 & 9,5 & 10,1 & 9,7 & 9,6 \\
\hline \multicolumn{6}{|l|}{ в том числе на оплату: } \\
\hline жилья & 1,2 & 1,6 & 1,6 & 1,6 & 1,6 \\
\hline электроэнергии & 1,2 & 1,4 & 1,4 & 1,4 & 1,4 \\
\hline газа & 0,9 & 1,0 & 1,0 & 0,9 & 0,9 \\
\hline центрального отопления & 2,2 & 2,1 & 2,2 & 2,2 & 2,2 \\
\hline воды и других коммунальных услуг & 3,7 & 3,4 & 3,8 & 3,5 & 3,5 \\
\hline & \multicolumn{5}{|c|}{ Домашние хозяйства в городской местности } \\
\hline \multirow{2}{*}{\multicolumn{6}{|c|}{$\begin{array}{l}\text { Расходы на оплату жилищно-коммунальных } \\
\text { услуг - всего }\end{array}$}} \\
\hline & 9,4 & 9,7 & 10,4 & 9,9 & 9,8 \\
\hline \multicolumn{6}{|l|}{ в том числе на оплату: } \\
\hline жилья & 1,3 & 1,7 & 1,8 & 1,7 & 1,6 \\
\hline электроэнергии & 1,2 & 1,3 & 1,3 & 1,3 & 1,3 \\
\hline газа & 0,5 & 0,6 & 0,6 & 0,6 & 0,6 \\
\hline центрального отопления & 2,4 & 2,3 & 2,5 & 2,4 & 2,4 \\
\hline \multirow[t]{2}{*}{ воды и других коммунальных услуг } & 4,0 & 3,8 & 4,2 & 3,8 & 3,9 \\
\hline & \multicolumn{5}{|c|}{ Домашние хозяйства в сельской местности } \\
\hline $\begin{array}{l}\text { Расходы на оплату жилищно-коммунальных } \\
\text { услуг - всего }\end{array}$ & 8,4 & 8,5 & 8,7 & 8,8 & 8,7 \\
\hline в том числе на оплату: & & & & & \\
\hline жилья & 0,9 & 1,0 & 1,0 & 1,1 & 1,2 \\
\hline электроэнергии & 1,7 & 1,9 & 1,9 & 2,0 & 2,0 \\
\hline газа & 2,5 & 2,5 & 2,7 & 2,6 & 2,6 \\
\hline центрального отопления & 1,4 & 1,3 & 1,2 & 1,2 & 1,1 \\
\hline воды и других коммунальных услуг & 1,9 & 1,9 & 1,9 & 1,9 & 1,9 \\
\hline
\end{tabular}




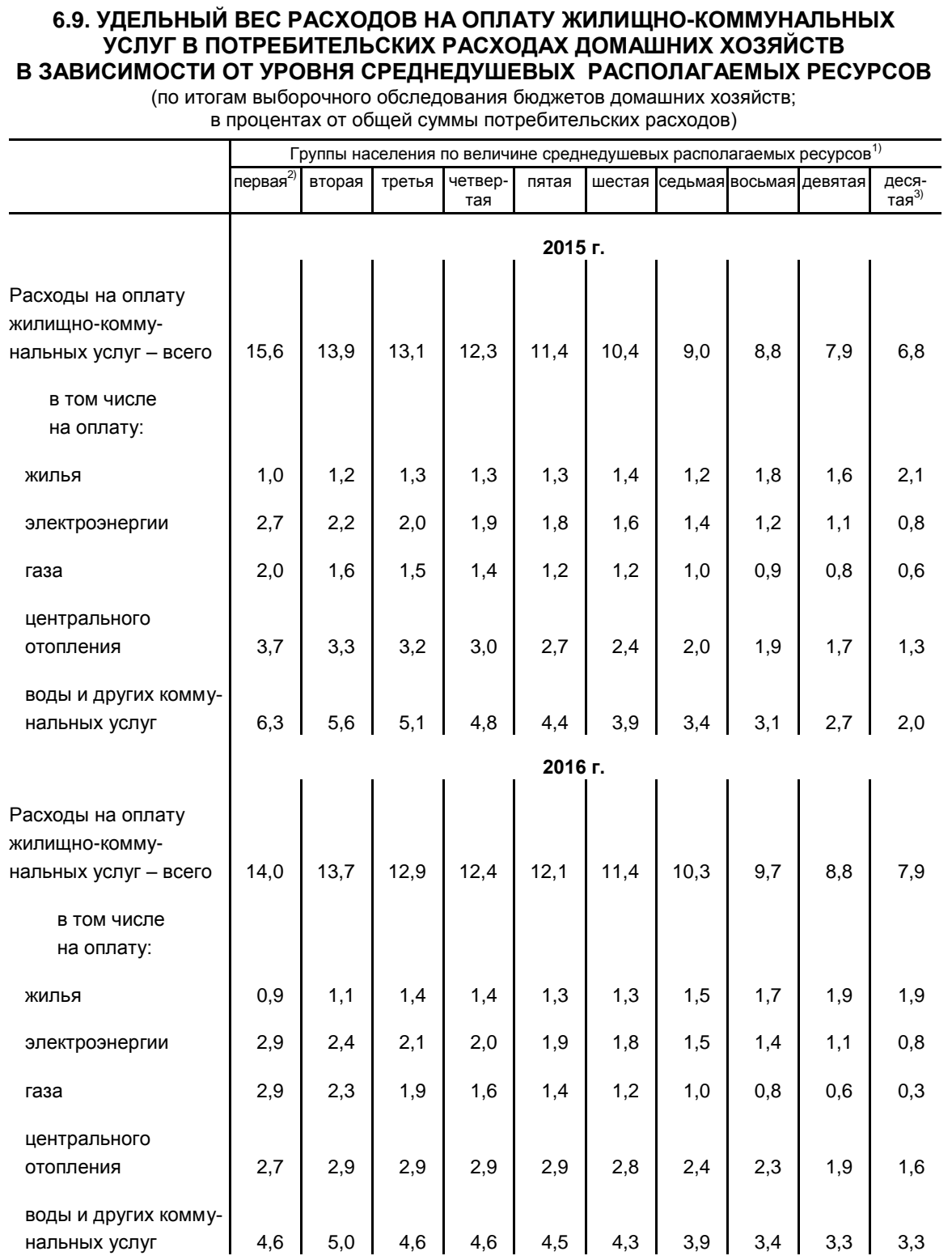


Продолжение табл. 6.9

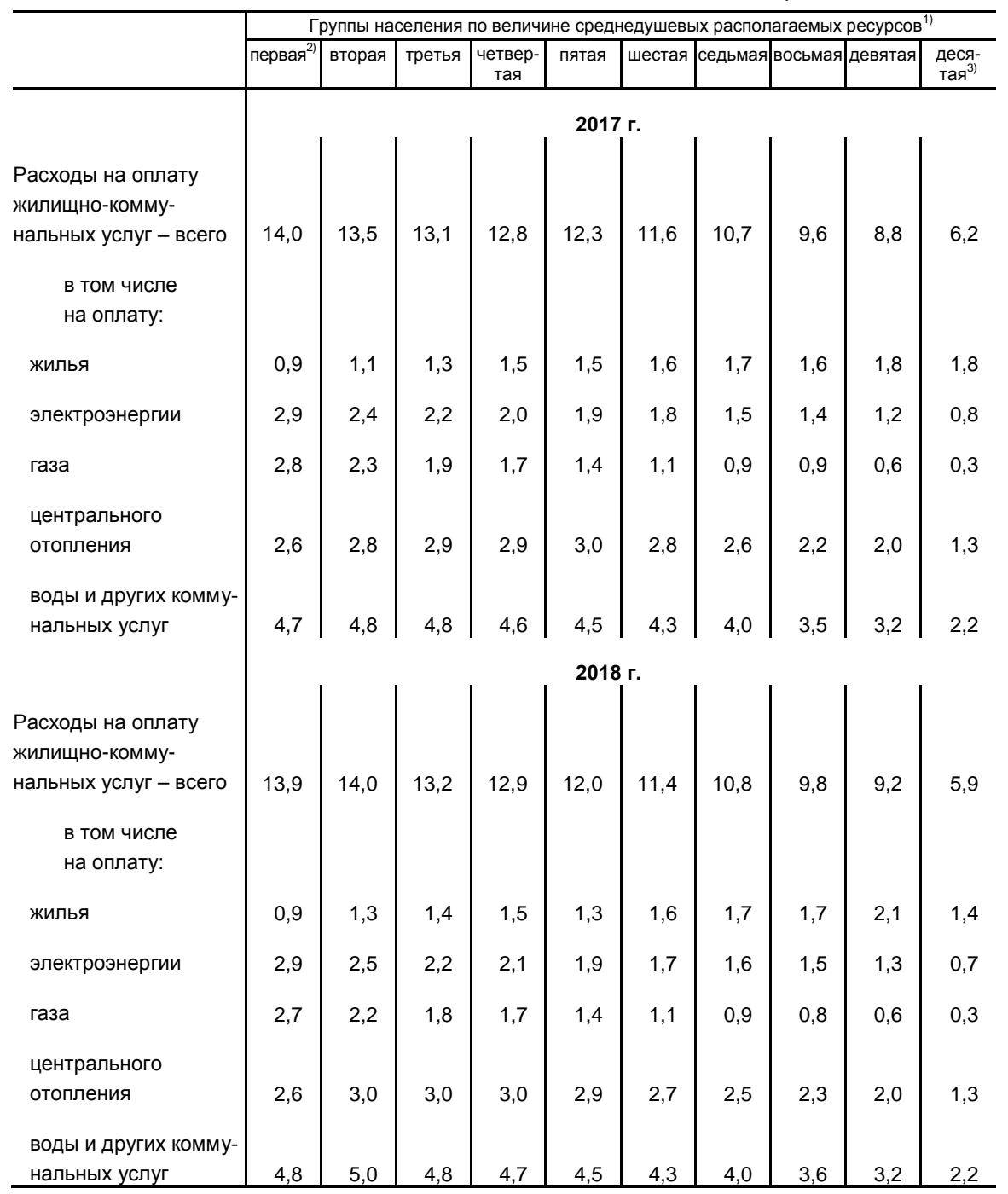

1) Располагаемые ресурсы домашних хозяйств представляют собой сумму средств (денежных и натуральных), которыми располагали домашние хозяйства для обеспечения всех своих расходов и создания сбережений в период обследования.

2) С наименьшими располагаемыми ресурсами.

3) С наибольшими располагаемыми ресурсами. 


\subsection{0. ИНДЕКСЫ ПОТРЕБИТЕЛЬСКИХ ТАРИФОВ НА ОТДЕЛЬНЫЕ ГРУППЫ И ВИДЫ ЖИЛИЩНО-КОММУНАЛЬНЫХ УСЛУГ}

(декабрь к декабрю предыдущего года; в процентах)

\begin{tabular}{|c|c|c|c|c|c|}
\hline & 2010 & 2015 & 2016 & 2017 & 2018 \\
\hline Все товары и услуги & 108,8 & 112,9 & 105,4 & 102,5 & 104,3 \\
\hline Жилищно-коммунальные услуги & 113,0 & 110,1 & 105,4 & 104,6 & 103,7 \\
\hline $\begin{array}{l}\text { жилищные услуги } \\
\text { из них: }\end{array}$ & 107,9 & 112,1 & 105,5 & 104,8 & 103,2 \\
\hline плата за жилье в домах государственного & & & & & \\
\hline $\begin{array}{l}\text { и муниципального жилищных фондов } \\
\text { содержание и ремонт жилья для граждан } \\
\text { собственников жилья в результате }\end{array}$ & 108,2 & 112,1 & 108,6 & 107,6 & 104,0 \\
\hline $\begin{array}{l}\text { приватизации, граждан собственников } \\
\text { жилых помещений по иным основаниям } \\
\text { услуги по организации и выполнению работ }\end{array}$ & 107,8 & 113,4 & 105,8 & 105,3 & 103,6 \\
\hline по эксплуатации домов ЖК, ЖСК, ТС ${ }^{1}$ & 108,9 & 114,2 & 105,7 & 105,2 & 103,1 \\
\hline взносы на капитальный ремонт, м² & & & & 104,9 & 103,8 \\
\hline $\begin{array}{l}\text { коммунальные услуги } \\
\text { из них: }\end{array}$ & 115,3 & 109,1 & 105,3 & 104,6 & 104,1 \\
\hline водоснабжение холодное, м³ & & 110,4 & 106,5 & 105,5 & 105,0 \\
\hline водоотведение, м³ & & 110,6 & 108,1 & 106,9 & 105,7 \\
\hline водоснабжение горячее, м³ & 115,5 & 109,6 & 105,9 & 105,5 & 104,4 \\
\hline отопление, Гкал & & 109,5 & 105,2 & 103,8 & 103,8 \\
\hline газ сетевой ${ }^{2)}$ & 117,8 & 107,3 & 101,1 & 104,3 & 103,0 \\
\hline газ сжиженный & 114,7 & 105,9 & 103,6 & 102,3 & 102,6 \\
\hline электроэнергия & 112,0 & 108,4 & 105,8 & 104,1 & 103,9 \\
\hline
\end{tabular}

1) 2015 - 2016 гг. - включая взнос на капитальный ремонт.

2) 2010 г. - газ сетевой, за месяц с человека.

\subsection{1. ИНДЕКСЫ ПОТРЕБИТЕЛЬСКИХ ТАРИФОВ}

(декабрь к декабрю предыдущего года)

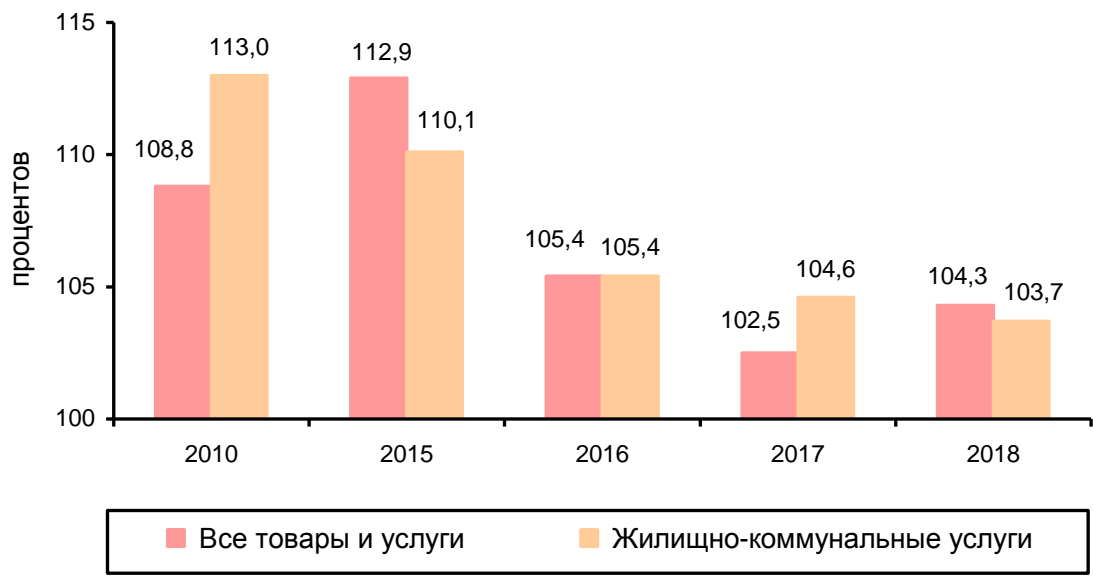




\subsection{2. СРЕДНИЕ ПОТРЕБИТЕЛЬСКИЕ ТАРИФЫ НА ОТДЕЛЬНЫЕ ВИДЫ ЖИЛИЩНО-КОММУНАЛЬНЫХ УСЛУГ}

(на конец года; рублей)

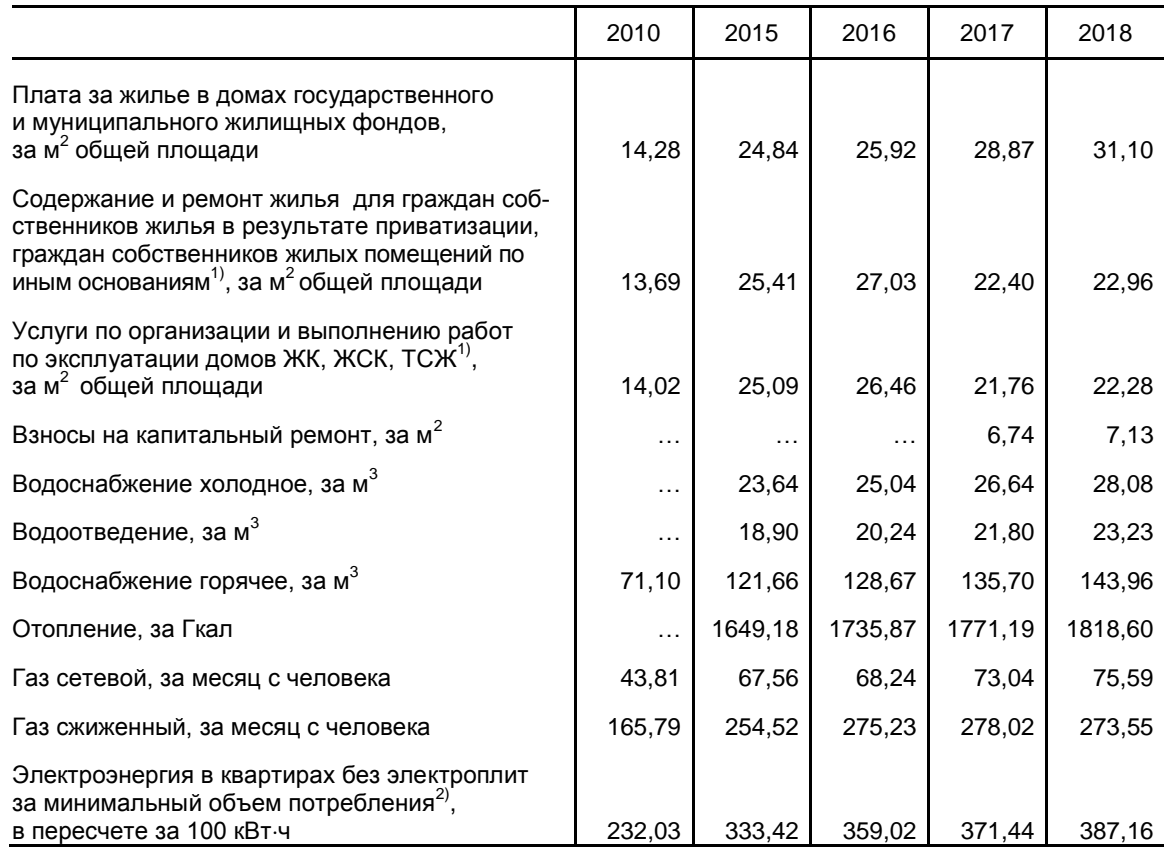

1) 2015 - 2016 гг. - включая взнос на капитальный ремонт.

2) 2010 г. - электроэнергия в квартирах без электроплит.

\subsection{3. РАСХОДЫ НА РЕАЛИЗАЦИЮ МЕР СОЦИАЛЬНОЙ ПОДДЕРЖКИ ГРАЖДАН ПО ОБЯЗАТЕЛЬСТВАМ СУБЪЕКТОВ РОССИЙСКОЙ ФЕДЕРАЦИИ И МУНИЦИПАЛЬНЫХ ОБРАЗОВАНИЙ НА ОПЛАТУ ЖИЛЬЯ И КОММУНАЛЬНЫХ УСЛУГ в 2018 г.}

(миллионов рублей)

\begin{tabular}{l|c|c|c}
\hline & Расходы - всего & \multicolumn{2}{|c}{ в том числе } \\
\cline { 3 - 4 } & & $\begin{array}{c}\text { в натуральной } \\
\text { форме }\end{array}$ & $\begin{array}{c}\text { в денежной } \\
\text { форме }\end{array}$ \\
\hline $\begin{array}{l}\text { Оплата жилого помещения } \\
\text { и коммунальных услуг }\end{array}$ & 134119,9 & 22195,5 & 111924,3 \\
Обеспечение жилыми помещениями & 19005,0 & 9847,2 & 9157,8 \\
Обеспечение топливом & 2838,2 & 11,6 & 2826,6 \\
Оплата и установка телефона & 6268,4 & 2,7 & 6265,7 \\
\hline
\end{tabular}




\subsection{4. ПРЕДОСТАВЛЕНИЕ ГРАЖДАНАМ СОЦИАЛЬНОЙ ПОДДЕРЖКИ ПО ОПЛАТЕ ЖИЛОГО ПОМЕЩЕНИЯ И КОММУНАЛЬНЫХ УСЛУГ}

\begin{tabular}{c|c|c|c}
\hline Годы & $\begin{array}{c}\text { Численность граждан, } \\
\text { пользующихся } \\
\text { социальной } \\
\text { поддержкой, } \\
\text { млн человек }\end{array}$ & $\begin{array}{c}\text { Объем средств, предусмотренных } \\
\text { на предоставление гражданам } \\
\text { социальной поддержки } \\
\text { по оплате жилого помещения } \\
\text { и коммунальных услуг, млрд руб. }\end{array}$ & $\begin{array}{c}\text { Среднемесячный размер } \\
\text { социальной поддержки } \\
\text { на одного пользователя, руб. }\end{array}$ \\
\hline 2010 & 37,5 & 214,5 & 477 \\
2015 & 36,7 & 287,7 & 654 \\
2016 & 36,0 & 290,8 & 674 \\
2017 & 35,1 & 292,5 & 695 \\
2018 & 34,8 & 298,1 & 715 \\
\hline
\end{tabular}

\subsection{5. СРЕДНЕМЕСЯЧНЫЙ РАЗМЕР СОЦИАЛЬНОЙ ПОДДЕРЖКИ} НА ОДНОГО ПОЛЬЗОВАТЕЛЯ

$$
\text { (рублей) }
$$

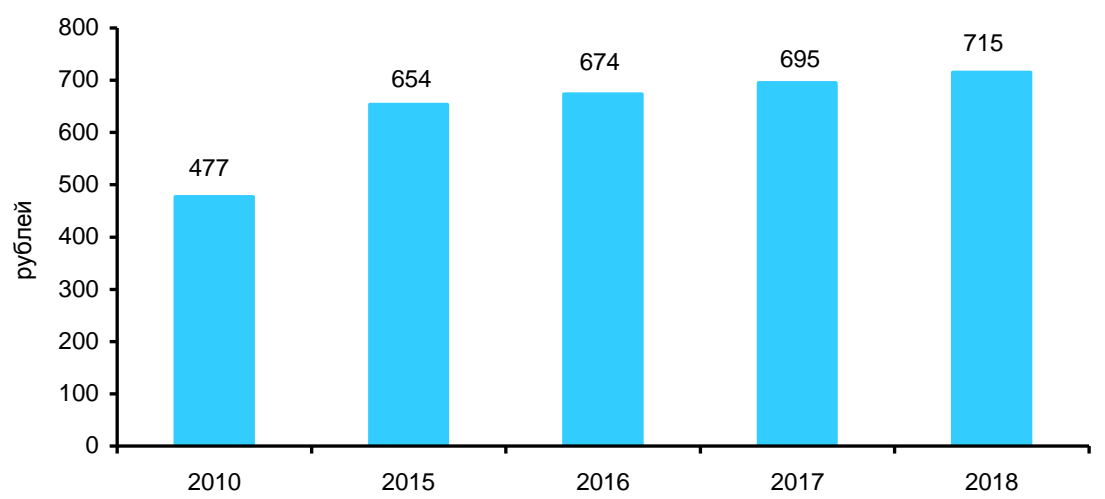

\subsection{6. ПРЕДОСТАВЛЕНИЕ ГРАЖДАНАМ СУБСИДИЙ НА ОПЛАТУ ЖИЛОГО ПОМЕЩЕНИЯ И КОММУНАЛЬНЫХ УСЛУГ}

\begin{tabular}{|c|c|c|c|c|c|}
\hline \multirow[t]{2}{*}{ Годы } & \multirow{2}{*}{$\begin{array}{l}\text { Число служб } \\
\text { субсидий }\end{array}$} & \multicolumn{2}{|c|}{ Число семей, получивших субсидии } & \multirow{2}{*}{$\begin{array}{c}\text { Общая сумма } \\
\text { начисленных } \\
\text { субсидий, } \\
\text { млрд руб. }\end{array}$} & \multirow{2}{*}{$\begin{array}{l}\text { Среднемесячный } \\
\text { размер субсидий } \\
\text { на семью, руб. }\end{array}$} \\
\hline & & млн & $\begin{array}{c}\text { в процентах } \\
\text { от общего числа } \\
\text { семей }^{1)}\end{array}$ & & \\
\hline 2010 & 2953 & 3,76 & 7,3 & 55,7 & 896 \\
\hline 2015 & 2543 & 3,35 & 6,0 & 62,7 & 1241 \\
\hline 2016 & 2492 & 3,34 & 6,0 & 68,8 & 1372 \\
\hline 2017 & 2502 & 3,19 & 5,7 & 70,3 & 1456 \\
\hline 2018 & 2495 & 3,04 & 5,4 & 68,7 & 1483 \\
\hline
\end{tabular}

1) 2015 - 2018 гг. - показатель рассчитан исходя из ориентировочной оценки числа семей, основанной на данных Всероссийской переписи населения 2010 года о среднем размере частных домохозяйств. 


\subsection{7. СРЕДНЕМЕСЯЧНЫЙ РАЗМЕР СУБСИДИЙ НА СЕМЬЮ \\ (рублей)}

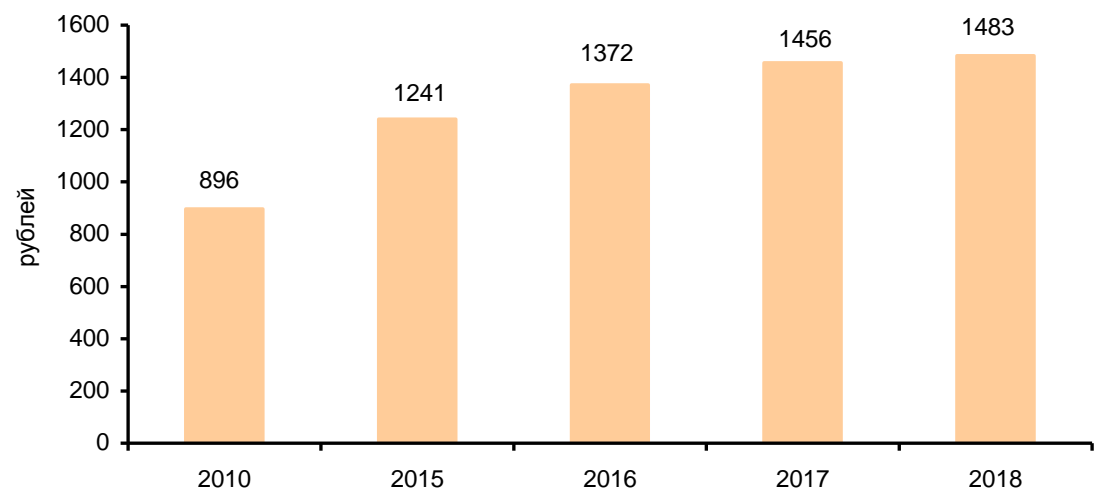

\section{ЭНЕРГОСБЕРЕЖЕНИЕ В ЖИЛИЩНО-КОММУНАЛЬНОМ ХОЗЯЙСТВЕ}

\subsection{8. ЗАТРАТЫ ОРГАНИЗАЦИЙ КОММУНАЛЬНОГО КОМПЛЕКСА НА МЕРОПРИЯТИЯ ПО ЭНЕРГОСБЕРЕЖЕНИЮ}

(на конец года; миллионов рублей)

\begin{tabular}{l|r|r|r|r|r}
\hline & 2010 & 2015 & 2016 & 2017 & 2018 \\
\hline $\begin{array}{l}\text { Затраты организаций водопроводных хозяйств } \\
\text { на мероприятия по энергосбережению }\end{array}$ & 1552,7 & 2523,0 & 2573,4 & 2560,8 & 2139,0 \\
$\begin{array}{l}\text { Затраты организаций канализационных хозяйств } \\
\text { на мероприятия по энергосбережению }\end{array}$ & 594,7 & 1770,8 & 1018,0 & 997,1 & 1147,2 \\
$\begin{array}{l}\text { Затраты организаций снабжающих теплоэнерги- } \\
\text { ей и горячей водой на мероприятия по энерго- } \\
\text { сбережению }\end{array}$ & 12185,4 & 18777,1 & 29769,7 & 27466,0 & 27885,1 \\
\hline
\end{tabular}

\subsection{9. ЭКОНОМИЯ, ПОЛУЧЕННАЯ ОРГАНИЗАЦИЯМИ КОММУНАЛЬНОГО КОМПЛЕКСА ОТ ПРОВЕДЕННЫХ МЕРОПРИЯТИЙ ПО ЭНЕРГОСБЕРЕЖЕНИЮ}

(на конец года; миллионов рублей)

\begin{tabular}{l|c|c|c|c|c}
\hline & 2010 & 2015 & 2016 & 2017 & 2018 \\
\hline $\begin{array}{l}\text { Экономия, полученная от проведенных меро- } \\
\text { приятий по энергосбережению организациями } \\
\text { водопроводных хозяйств }\end{array}$ & 405,0 & 494,6 & 503,6 & 582,9 & 498,6 \\
$\begin{array}{l}\text { Экономия, полученная от проведенных меро- } \\
\text { приятий по энергосбережению организациями } \\
\text { канализационных хозяйств }\end{array}$ & 150,7 & 171,4 & 231,0 & 211,5 & 380,7 \\
$\begin{array}{l}\text { Экономия, полученная от проведенных меро- } \\
\text { приятий по энергосбережению организаций } \\
\text { снабжающих теплоэнергией и горячей водой }\end{array}$ & 1823,1 & 4915,6 & 4124,8 & 4619,2 & 5630,1 \\
\hline
\end{tabular}




\subsection{0. ЧИСЛО МНОГОКВАРТИРНЫХ ДОМОВ И КВАРТИР, ОСНАЩЕННЫХ ПРИБОРАМИ УЧЕТА ПОТРЕБЛЯЕМЫХ КОММУНАЛЬНЫХ РЕСУРСОВ}






\subsection{1. ОБЪЕМ ОТПУСКА КОММУНАЛЬНЫХ УСЛУГ, СЧЕТ ЗА КОТОРЫЕ ВЫСТАВЛЕН ПО ПОКАЗАНИЯМ ПРИБОРОВ УЧЕТА ${ }^{1)}$}

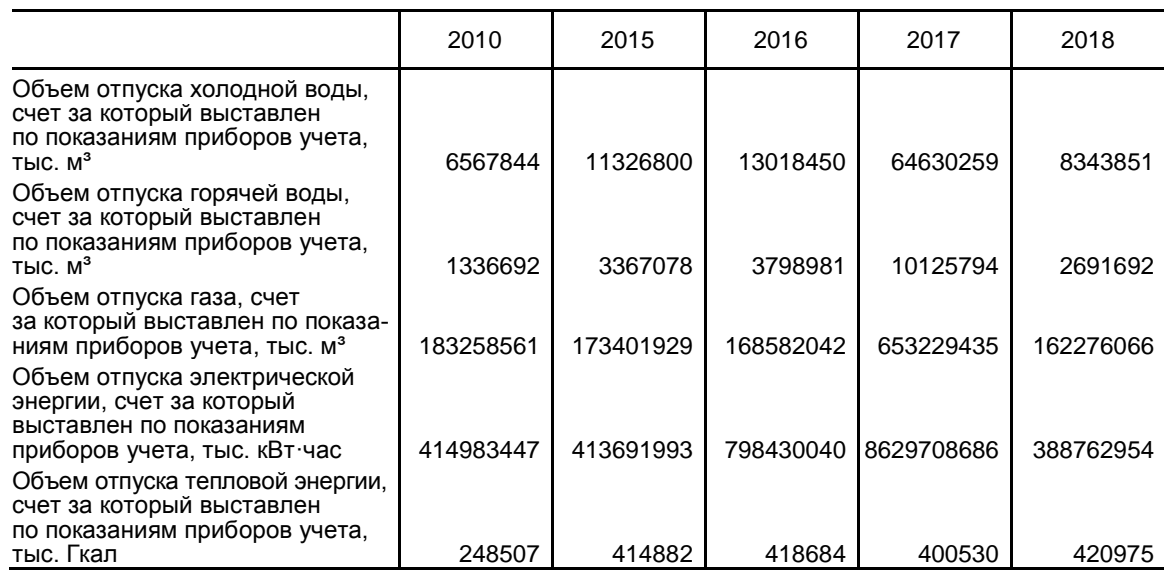

1) По данным Минстроя России.

\subsection{2. УДЕЛЬНЫЙ ВЕС ОБЪЕМА ОТПУСКА КОММУНАЛЬНЫХ УСЛУГ, СЧЕТ ЗА КОТОРЫЕ ВЫСТАВЛЕН ПО ПОКАЗАНИЯМ ПРИБОРОВ УЧЕТА, В ОБЩЕМ ОБЪЕМЕ ОТПУСКА КОММУНАЛЬНЫХ УСЛУГ}

(в процентах)

\begin{tabular}{|c|c|c|c|c|c|}
\hline & 2010 & 2015 & 2016 & 2017 & 2018 \\
\hline $\begin{array}{l}\text { Удельный вес объема отпуска } \\
\text { холодной воды, счет за который } \\
\text { выставлен по показаниям прибо- } \\
\text { ров учета, в общем объеме } \\
\text { отпуска холодной воды } \\
\text { Удельный вес объема отпуска } \\
\text { горячей воды, счет за который } \\
\text { выставлен по показаниям прибо- } \\
\text { ров учета, в общем объеме } \\
\text { отпуска горячей воды } \\
\text { Удельный вес объема отпуска } \\
\text { газа, счет за который выставлен } \\
\text { по показаниям приборов учета, } \\
\text { в общем объеме отпуска газа } \\
\text { Удельный вес объема отпуска } \\
\text { электрической энергии, счет за } \\
\text { который выставлен по показани- } \\
\text { ям приборов учета, в общем } \\
\text { объеме отпуска электрической } \\
\text { энергии } \\
\text { Удельный вес объема отпуска } \\
\text { тепловой энергии, счет за кото- } \\
\text { рый выставлен по показаниям } \\
\text { приборов учета, в общем объеме } \\
\text { отпуска тепловой энергии }\end{array}$ & 87,8 & 95,1 & 86,9 & 99,0 & 68,9 \\
\hline
\end{tabular}

1) По данным Минстроя России. 


\section{1. ИНДЕКСЫ ФИЗИЧЕСКОГО ОБЪЕМА ПЛАТНЫХ УСЛУГ НАСЕЛЕНИЮ}

(в сопоставимых ценах; в процентах к предыдущему году)

\begin{tabular}{|c|c|c|c|c|c|}
\hline & 2010 & 2015 & 2016 & 2017 & 2018 \\
\hline & \multicolumn{5}{|c|}{ Все оказанные услуги } \\
\hline Россия & 101,5 & 98,9 & 100,7 & 101,4 & 101,4 \\
\hline Азербайджан & 110,8 & 105,1 & 98,9 & 101,2 & 103,0 \\
\hline Армения & 103,4 & $\ldots$ & $\ldots$ & $\ldots$ & $\ldots$ \\
\hline Беларусь & 111,5 & 97,7 & 95,6 & 103,7 & 106,3 \\
\hline Республика Молдова & 103,9 & 101,2 & 100,6 & 99,6 & 110,9 \\
\hline США & $\ldots$ & $\ldots$ & $\ldots$ & $\ldots$ & $\ldots$ \\
\hline Таджикистан & 113,2 & 92,4 & 99,5 & 102,3 & 97,6 \\
\hline \multirow[t]{2}{*}{ Узбекистан } & 112,5 & 110,7 & 109,3 & $\ldots$ & $\cdots$ \\
\hline & \multicolumn{5}{|c|}{ Жилищно-коммунальные услуги } \\
\hline Россия & 104,7 & 98,7 & 100,2 & 103,4 & 100,7 \\
\hline Азербайджан & 95,4 & 103,5 & 100,9 & 101,2 & 103,3 \\
\hline Армения & 119,5 & $\ldots$ & $\ldots$ & $\ldots$ & $\ldots$ \\
\hline Беларусь ${ }^{1)}$ & 105,7 & 99,6 & 90,6 & 100,0 & 98,8 \\
\hline Республика Молдова²) & 106,6 & $\ldots$ & $\ldots$ & $\ldots$ & $\ldots$ \\
\hline США ${ }^{3)}$ & 104,1 & $\ldots$ & $\ldots$ & $\ldots$ & $\cdots$ \\
\hline Таджикистан & 71,1 & 100,8 & 104,5 & 109,8 & 150,8 \\
\hline \multirow[t]{2}{*}{ Узбекистан } & $\ldots$ & $\ldots$ & $\ldots$ & $\ldots$ & $\ldots$ \\
\hline & \multicolumn{5}{|c|}{ Бытовые услуги населению } \\
\hline Россия & 102,9 & 101,1 & 100,8 & 100,5 & 102,4 \\
\hline Азербайджан & 108,8 & 106,5 & 99,8 & 99,8 & 101,5 \\
\hline Армения & 118,7 & $\ldots$ & $\ldots$ & $\ldots$ & $\ldots$ \\
\hline Беларусь & 121,7 & 97,7 & 95,2 & 99,6 & 104,6 \\
\hline Республика Молдова ${ }^{2)}$ & $\ldots$ & $\ldots$ & $\ldots$ & $\ldots$ & $\ldots$ \\
\hline США & $\cdots$ & $\ldots$ & $\ldots$ & $\ldots$ & $\cdots$ \\
\hline Таджикистан & 116,0 & 93,7 & 90,1 & 102,2 & 100,6 \\
\hline Узбекистан & 108,5 & 116,1 & 114,5 & $\ldots$ & $\ldots$ \\
\hline
\end{tabular}

1) Без учета гостиниц и аналогичных средств размещения.

2) Предприятия.

3) Коммунальные услуги предприятиям, организациям и населению. 
7.2. ВВОД В ДЕЙСТВИЕ ЖИЛЫХ ДОМОВ

(миллионов квадратных метров общей площади)

\begin{tabular}{|c|c|c|c|c|c|}
\hline & 2010 & 2015 & 2016 & 2017 & 2018 \\
\hline Россия & 58,4 & 85,3 & 80,2 & 79,2 & 75,7 \\
\hline \multicolumn{6}{|l|}{ Европа } \\
\hline Беларусь & 6,6 & 5,1 & 4,3 & 3,8 & 4,0 \\
\hline Бельгия") & 5,1 & 4,3 & 7,8 & 8,1 & $\ldots$ \\
\hline Болгария & 1,2 & 0,7 & 0,8 & 0,7 & $\ldots$ \\
\hline Венгрия & 1,9 & 0,8 & 0,9 & 1,4 & 1,8 \\
\hline Германия²) & 19,0 & 27,2 & 29,1 & 29,8 & 29,6 \\
\hline Греция ${ }^{3)}$ & 3,9 & 0,5 & 0,6 & $\ldots$ & $\ldots$ \\
\hline Дания & 1,8 & 2,0 & 2,3 & 2,7 & $\ldots$ \\
\hline Латвия & 0,4 & 0,4 & 0,4 & 0,4 & ... \\
\hline Литва & 0,5 & 1,2 & 1,4 & 1,2 & $\ldots$ \\
\hline Норвегия ${ }^{4)}$ & 2,4 & 3,7 & 3,8 & 4,1 & $\ldots$ \\
\hline Польша & 14,4 & 14,7 & 15,4 & 16,5 & 16,7 \\
\hline Португалия ${ }^{4)}$ & 11,4 & 1,7 & 1,6 & 2,1 & $\ldots$ \\
\hline Республика Молдова & 0,5 & 0,6 & 0,5 & 0,7 & 0,6 \\
\hline Румыния & 6,0 & 5,1 & 5,6 & 5,7 & ... \\
\hline Словакия & 1,9 & $1,1^{2)}$ & $1,2^{2)}$ & $1,2^{2)}$ & $\ldots$ \\
\hline Словения") & 1,1 & 0,6 & 0,6 & 0,7 & $\ldots$ \\
\hline Украина & 9,3 & 11,0 & 9,4 & 10,2 & $8,7^{6)}$ \\
\hline Финляндия & 2,4 & 2,2 & 2,2 & 2,3 & $\ldots$ \\
\hline Франция ${ }^{1)}$ & 36,6 & 28,1 & 30,4 & 35,0 & $\ldots$ \\
\hline Чехия $^{2)}$ & 2,8 & 1,9 & 2,0 & 2,1 & $\cdots$ \\
\hline Эстония & 0,2 & 0,4 & 0,5 & 0,5 & $\ldots$ \\
\hline \multicolumn{6}{|l|}{ Азия } \\
\hline Азербайджан & 2,0 & 1,9 & 2,1 & 2,0 & 2,2 \\
\hline Армения & 0,5 & 0,3 & 0,2 & 0,2 & 0,3 \\
\hline Казахстан & 6,4 & 8,9 & 10,5 & 11,2 & 12,5 \\
\hline Киргизия & 0,7 & 1,2 & 1,2 & 1,5 & 1,3 \\
\hline Таджикистан & 1,0 & 1,3 & 1,2 & 1,2 & 1,2 \\
\hline Турция ${ }^{3)}$ & 90,5 & 107,9 & $\ldots$ & $\ldots$ & ... \\
\hline Узбекистан & 8,9 & 12,1 & 11,3 & 11,5 & 13,4 \\
\hline Япония ${ }^{1)}$ & 72,9 & 75,1 & 78,2 & 77,5 & $\ldots$ \\
\hline
\end{tabular}

1) Начатое строительство.

${ }^{2)}$ Жилая площадь.

3) Разрешенное строительство.

4) Исключая капитальный ремонт.

5) Разрешенное строительство, исключая реставрацию.

${ }^{6)}$ Новое жилищное строительство. 


\section{3. ЧИСЛО ПОСТРОЕННЫХ КВАРТИР}

(тысяч)

\begin{tabular}{|c|c|c|c|c|c|}
\hline & 2010 & 2015 & 2016 & 2017 & 2018 \\
\hline Россия & 717 & 1195 & 1167 & 1139 & 1076 \\
\hline Беларусь & 84,7 & 55,5 & 49,3 & 43,4 & 46.9 \\
\hline Бельгия ${ }^{1)}$ & 48,1 & 43,5 & 44,9 & 49,4 & $\ldots$ \\
\hline Болгария & 15,8 & 7,8 & 9,3 & 8,4 & $\ldots$ \\
\hline Венгрия & 20,8 & 7,6 & 10,0 & 14,4 & 17,7 \\
\hline Германия & 159,8 & 247,7 & 277,7 & 284,8 & 285,9 \\
\hline Греция 2) & 41,0 & 5,5 & 5,7 & $\ldots$ & $\ldots$ \\
\hline Дания & 11,1 & 14,6 & 19,2 & 23,4 & $\ldots$ \\
\hline Ирландия & 14,6 & 12,7 & 14,9 & 19,3 & $\ldots$ \\
\hline Испания & 257,4 & 45,6 & $\ldots$ & $\ldots$ & $\ldots$ \\
\hline Латвия & 1,9 & 2,2 & 2,2 & 2,3 & $\ldots$ \\
\hline Литва & 3,7 & 10,2 & 12,7 & 11,0 & $\ldots$ \\
\hline Нидерланды & 56,0 & $\ldots$ & $\ldots$ & $\ldots$ & $\ldots$ \\
\hline Норвегия ${ }^{3)}$ & 18,1 & 28,3 & 29,3 & 31,5 & $\ldots$ \\
\hline Польша & 135,8 & 147,7 & 163,3 & 178,3 & 185,1 \\
\hline Португалия & 38,3 & 7,2 & 6,8 & 8,7 & $\ldots$ \\
\hline Республика Молдова & 4,9 & 7,6 & 6,1 & 9,2 & 7,3 \\
\hline Румыния & 48,9 & 47,0 & 52,2 & 53,3 & $\ldots$ \\
\hline Словакия & 17,1 & 15,5 & 15,7 & 16,9 & $\ldots$ \\
\hline Словения ${ }^{4)}$ & 4,7 & 2,6 & 2,8 & 3,0 & $\ldots$ \\
\hline $\begin{array}{l}\text { Соединенное Королевство } \\
\text { (Великобритания) }\end{array}$ & 135,9 & 171,8 & 170,9 & 194,7 & \\
\hline Украина & 76,8 & 120,3 & 112,6 & 125,6 & $103,1^{5}$ \\
\hline Финляндия & 25,2 & 27,7 & 30,2 & 35,7 & ... \\
\hline Франция ${ }^{1)}$ & 414,5 & 336,7 & 369,1 & 430,2 & ... \\
\hline Чехия & 36,4 & 25,1 & 27,3 & 28,6 & $\ldots$ \\
\hline Швейцария & 40,2 & $\ldots$ & $\ldots$ & $\ldots$ & $\ldots$ \\
\hline Швеция & 16,6 & 30,3 & 42,4 & 42,6 & $\ldots$ \\
\hline Эстония & 2,3 & 4,0 & 4,7 & 5,9 & $\ldots$ \\
\hline \multicolumn{6}{|l|}{ Азия } \\
\hline Азербайджан & 17,6 & 16,2 & 14,6 & 15,4 & 16,5 \\
\hline Армения & 3,6 & 2,0 & 1,3 & 1,6 & 1,8 \\
\hline Казахстан & 54,7 & 78,7 & 89,3 & 100,8 & 113,5 \\
\hline Киргизия & 7,7 & 12,3 & 12,1 & 15,4 & 12,6 \\
\hline Таджикистан & 19,2 & 14,4 & 13,1 & 12,4 & 12,0 \\
\hline Турция ${ }^{2)}$ & 584,3 & 714,1 & $\ldots$ & $\ldots$ & $\ldots$ \\
\hline Узбекистан & 75,3 & 88,3 & 82,0 & 94,6 & 107,7 \\
\hline Япония ${ }^{1)}$ & 813,0 & 909,0 & 967,0 & 965,0 & $\ldots$ \\
\hline \multicolumn{6}{|l|}{ Америка } \\
\hline США ${ }^{6)}$ & 648,0 & 969,0 & 1061 & 1152 & . \\
\hline
\end{tabular}

\footnotetext{
1) Начатое строительство.

2) Разрешенное строительство.

3) Исключая капитальный ремонт.

4) Разрешенное строительство, исключая реставрацию.

5) Новое жилищное строительство.

${ }^{6)}$ Неполный охват.
} 


\section{4. СРЕДНИЙ РАЗМЕР ПОСТРОЕННЫХ КВАРТИР}

(квадратных метров общей площади)

\begin{tabular}{|c|c|c|c|c|c|}
\hline & 2010 & 2015 & 2016 & 2017 & 2018 \\
\hline Россия & 82 & 71 & 69 & 70 & 70 \\
\hline \multicolumn{6}{|l|}{ Европа } \\
\hline Беларусь & 78 & 91 & 87 & 87 & 85 \\
\hline Бельгия") & 105 & 99 & 174 & 164 & ... \\
\hline Болгария & 76 & 93 & 84 & 87 & ... \\
\hline Венгрия & 92 & 101 & 94 & 100 & 99 \\
\hline Германия²) & 119 & 110 & 105 & 104 & 104 \\
\hline Греция ${ }^{3)}$ & 95 & 99 & 102 & $\ldots$ & $\ldots$ \\
\hline Дания & 166 & 138 & 121 & 117 & ... \\
\hline Латвия & 201 & 198 & 169 & 169 & ... \\
\hline Литва & 140 & 115 & 111 & 113 & ... \\
\hline Норвегия ${ }^{4)}$ & 135 & 130 & 128 & 129 & ... \\
\hline Польша & 106 & 100 & 95 & 93 & ... \\
\hline Португалия ${ }^{4)}$ & 299 & 243 & 239 & 240 & $\ldots$ \\
\hline Республика Молдова & 111 & 80 & 85 & 76 & 76 \\
\hline Румыния & 123 & 109 & 108 & 106 & $\cdots$ \\
\hline Словакия & 114 & $71^{2)}$ & $74^{2)}$ & $70^{2)}$ & $\ldots$ \\
\hline Словения") & 231 & 236 & 225 & 226 & $\ldots$ \\
\hline Украина & 122 & 87 & 80 & 79 & $84^{6)}$ \\
\hline Финляндия & 96 & 80 & 72 & 66 & $\ldots$ \\
\hline Франция ${ }^{1)}$ & 88 & 84 & 82 & 82 & $\ldots$ \\
\hline Чехия ${ }^{2)}$ & 77 & 75 & 73 & 73 & $\ldots$ \\
\hline Эстония & 104 & 100 & 99 & 92 & $\cdots$ \\
\hline \multicolumn{6}{|l|}{ Азия } \\
\hline Азербайджан & 117 & 119 & 145 & 131 & 136 \\
\hline Армения & 144 & 140 & 155 & 129 & 158 \\
\hline Казахстан & 117 & 114 & 118 & 111 & 110 \\
\hline Киргизия & 95 & 100 & 103 & 95 & 104 \\
\hline Таджикистан & 54 & 88 & 91 & 94 & 97 \\
\hline Турция ${ }^{3)}$ & 155 & 151 & $\ldots$ & $\ldots$ & $\ldots$ \\
\hline Узбекистан & 118 & 137 & 138 & 121 & 124 \\
\hline Япония ${ }^{1)}$ & 90 & 83 & 81 & 80 & $\ldots$ \\
\hline
\end{tabular}

1) Начатое строительство

2) Жилая площадь.

3) Разрешенное строительство.

4) Исключая капитальный ремонт.

5) Разрешенное строительство, исключая реставрацию.

${ }^{6)}$ Новое жилищное строительство. 


\section{5. ЖИЛЫЕ ПОМЕЩЕНИЯ ПО ВИДАМ БЛАГОУСТРОЙСТВА}

(в процентах)

\begin{tabular}{|c|c|c|c|c|c|c|c|}
\hline & \multirow{2}{*}{ Год } & \multirow{2}{*}{$\begin{array}{c}\text { Жилые } \\
\text { помещения } \\
\text { - всего }\end{array}$} & \multicolumn{4}{|c|}{ из них оборудованные } & \multirow{2}{*}{$\begin{array}{c}\text { Удельный } \\
\text { вес собст- } \\
\text { венного } \\
\text { жилья в } \\
\text { общем } \\
\text { числе } \\
\text { жилых } \\
\text { помещений }\end{array}$} \\
\hline & & & $\begin{array}{c}\text { водопро- } \\
\text { водом }\end{array}$ & $\begin{array}{c}\text { ванной или } \\
\text { душем }\end{array}$ & $\begin{array}{c}\text { санузлом } \\
\text { со } \\
\text { смывным } \\
\text { бачком }\end{array}$ & $\begin{array}{l}\text { централь- } \\
\text { ным отоп- } \\
\text { лением }\end{array}$ & \\
\hline \multirow[t]{2}{*}{ Россия } & 2017 & 100 & 82,4 & 69,9 & $77,6^{1)}$ & $85,9^{2)}$ & 91,5 \\
\hline & 2018 & 100 & 82,9 & 70,5 & $78,3^{1)}$ & $86,3^{2)}$ & 91,8 \\
\hline \multicolumn{8}{|l|}{ Европа } \\
\hline Австрия & 2003 & 100 & 99,9 & 98,3 & 99,1 & 89,8 & $56,9^{3)}$ \\
\hline Беларусь & 2017 & 100 & 78,1 & 71,6 & $76,7^{1)}$ & 77,2 & 94,1 \\
\hline Болгария & 2004 & 100 & 87,6 & $\ldots$ & 67,1 & 12,7 & $\ldots$ \\
\hline Венгрия & 2018 & 100 & 96,8 & 93,7 & 93,2 & $\ldots$ & $\ldots$ \\
\hline Греция & 2001 & 100 & 98,1 & 92,3 & 92,6 & 56,3 & 74,3 \\
\hline Латвия & 2003 & 100 & 83,0 & 66,0 & 78,0 & 64,9 & 70,7 \\
\hline Литва & 2008 & 100 & 76,5 & 71,1 & 75,1 & 73,5 & $\ldots$ \\
\hline Нидерланды & 2002 & 100 & $\ldots$ & $\ldots$ & $\ldots$ & 90,2 & 54,2 \\
\hline Польша & 2017 & 100 & 96,8 & 91,4 & 93,7 & 82,3 & $\ldots$ \\
\hline Португалия & 2001 & 100 & 67,5 & 64,7 & $\ldots$ & 3,7 & 75,7 \\
\hline Республика Молдова & 2018 & 100 & 59,6 & 38,1 & $57,5^{1)}$ & 46,4 & 99,3 \\
\hline Словения & 2009 & 100 & $\ldots$ & 92,8 & $\ldots$ & 80,0 & $83,5^{4)}$ \\
\hline $\begin{array}{l}\text { Соединенное } \\
\text { Королевство } \\
\text { (Великобритания) }\end{array}$ & 2003 & 100 & 99,9 & 99,9 & 99,9 & 86,9 & 69,2 \\
\hline Украина ${ }^{5)}$ & 2017 & 100 & 61,8 & $\ldots$ & $59,8^{1)}$ & 69,1 & $\ldots$ \\
\hline Финляндия & 2017 & 100 & 99 & $\ldots$ & 98 & 95 & 56,8 \\
\hline Франция & 2002 & 100 & $\ldots$ & $99,2^{6)}$ & $\ldots$ & $82,8^{6)}$ & 56,0 \\
\hline Чехия & 2001 & 100 & 86,4 & 83,7 & 82,2 & 64,5 & 46,9 \\
\hline Эстония & 2005 & 100 & 84,0 & 66,8 & 74,3 & 58,7 & $\ldots$ \\
\hline \multicolumn{8}{|l|}{ Азия } \\
\hline Азербайджан & 2017 & 100 & 73,1 & 62,0 & $59,4^{1)}$ & 20,4 & 94,5 \\
\hline Армения & 2017 & 100 & 97,0 & 89,1 & $71,8^{1)}$ & 0,2 & 99,0 \\
\hline Казахстан & 2017 & 100 & 98,4 & 42,0 & $68,4^{1)}$ & 40,6 & 97,8 \\
\hline Киргизия & 2018 & 100 & 36,0 & 15,0 & $25,8^{1)}$ & 13,6 & 98,2 \\
\hline Таджикистан & 2014 & 100 & 22,4 & 18,7 & $19,6^{1)}$ & 10,1 & 97,5 \\
\hline Узбекистан & 2018 & 100 & 75,7 & $\ldots$ & $35,7^{3)}$ & 44 & $\ldots$ \\
\hline Япония & 2008 & 100 & $\ldots$ & 95,5 & 90,7 & $\ldots$ & $61^{7)}$ \\
\hline \multicolumn{8}{|l|}{ Америка } \\
\hline США & 2003 & 100 & 99,2 & 99,7 & 99,7 & 88,9 & 68,3 \\
\hline
\end{tabular}

1) Водоотведение (канализация).

2) Жилые помещения, оборудованные отоплением.

3) 2004 г.

4) $2002 r$.

5) По данным Интернет-сайта Государственной службы статистики Украины.

6) 1999 г.

7) 2000 r. 


\section{МЕТОДОЛОГИЧЕСКИЕ ПОЯСНЕНИЯ}

\section{СОСТОЯНИЕ ЖИЛИЩНОГО ФОНДА \\ Жилищный фонд}

Раздел содержит данные о жилищном фонде и его структуре, а также обеспеченности населения жильем.

Жилищный фонд - совокупность всех жилых помещений, находящихся на территории Российской Федерации.

Жилым помещением признается изолированное помещение, которое является недвижимым имуществом и пригодно для постоянного проживания граждан, отвечает установленным санитарным и техническим правилам и нормам, иным требованиям законодательства.

В составе жилищного фонда не учитываются дачи, летние садовые домики, спортивные и туристские базы, мотели, кемпинги, санатории, дома отдыха, пансионаты, дома для приезжих, гостиницы, казармы, кельи, железнодорожные вагончики и другие строения.

В соответствии со статьей 19 (п.2) Жилищного кодекса Российской Федерации учет жилищного фонда ведется по следующим формам собственности:

частный жилищный фонд - совокупность жилых помещений, находящихся в собственности граждан и в собственности юридических лиц;

государственный жилищный фонд - совокупность жилых помещений, принадлежащих на праве собственности Российской Федерации (жилищный фонд Российской Федерации), и жилых помещений, принадлежащих на праве собственности субъектам Российской Федерации (жилищный фонд субъектов Российской Федерации);

муниципальный жилищный фонд - совокупность жилых помещений, принадлежащих на праве собственности муниципальным образованиям.

Общая площадь жилого помещения состоит из суммы площади всех частей такого помещения, включая площадь помещений вспомогательного использования, предназначенных для удовлетворения гражданами бытовых и иных нужд, связанных с их проживанием в жилом помещении, за исключением балконов, лоджий, веранд и террас.

Виды жилых помещений. К жилым помещениям относятся: жилой дом, часть жилого дома; квартира, часть квартиры; комната.

Жилым домом признается индивидуально-определенное здание, которое состоит из комнат, а также помещений вспомогательного использования, предназначенных для удовлетворения гражданами бытовых и иных нужд, связанных с их проживанием в таком здании.

Квартирой признается структурно обособленное помещение в многоквартирном доме, обеспечивающее возможность прямого доступа к помещениям общего пользования в таком доме и состоящее из одной или нескольких комнат, а также помещений вспомогательного использования, предназначенных для удовлетворения гражданами бытовых и иных нужд, связанных с их проживанием в таком обособленном помещении.

Комнатой признается часть жилого дома или квартиры, предназначенная для использования в качестве места непосредственного проживания граждан в жилом доме или квартире.

\section{ЖИЛИЩНЫЕ УСЛОВИЯ НАСЕЛЕНИЯ}

\section{Обеспеченность населения жильем}

Общая площадь жилых помещений, приходящаяся в среднем на одного жителя, рассчитывается делением размера всего жилого фонда по состоянию на конец года на численность постоянного населения на эту же дату. 


\section{Благоустройство жилищного фонда}

Раздел содержит данные о благоустройстве жилищного фонда и благоустройстве населенных пунктов.

Благоустройство жилищного фонда. Жилищный фонд может быть оборудован:

- водопроводом, если внутри дома имеется распределительная сеть водопровода, в которую вода поступает централизованно из водопровода или артезианской скважины;

- водоотведением (канализацией), если внутри имеется канализационное устройство для стока хозяйственно-фекальных вод в уличную канализационную сеть или поглощающие колодцы, местный отстойник. Жилищный фонд, не оборудованный водопроводом, не может быть оборудован канализацией. При этом площадь, оборудованная канализацией, не должна превышать площади, оборудованной водопроводом;

- отоплением независимо от источника поступления тепла: от ТЭЦ, промышленной котельной, квартальной, групповой, местной котельной, АГВ, индивидуального котла заводского изготовления или котла, вмонтированного в отопительную печь или другими источниками тепла за исключением печного отопления;

- газом как сетевым (природным), так и сжиженным, включая газовые баллоны, при наличии установленной напольной газовой плиты или встраиваемой газовой варочной панели, а также централизованно к системам газоснабжения;

- горячим водоснабжением от специальных водопроводов, подающих в жилые помещения горячую воду для бытовых нужд проживающих, централизованно или от местных водонагревателей;

- ваннами (душем) независимо от способа поступления горячей воды (система горячего водоснабжения) централизованного, либо оборудованного местными водонагревателями (местной котельной, АГВ, индивидуального котла заводского изготовления или котла, вмонтированного в отопительную печь, газовой (дровяной) колонкой); площадь, оборудованная ваннами, но не имеющая канализации, не считается оборудованной данным видом;

- напольными электроплитами при наличии установленной напольной электрической плиты или встраиваемой электрической варочной панели.

Благоустройство населенных пунктов. Населенные пункты, имеющие централизованное водоснабжение и канализацию - города, поселки городского типа, сельские населенные пункты, в которых водопроводы и отдельные водопроводные сети отпускают воду населению и бюджетофинансируемым организациям, а канализации осуществляют централизованный отвод сточных вод из жилых домов и бюджетофинансируемых организаций.

\section{Состояние инфраструктуры жилищного хозяйства}

Основные фонды - произведенные активы, подлежащие использованию неоднократно или постоянно в течение длительного периода, но не менее одного года, для производства товаров, оказания рыночных и нерыночных услуг, для управленческих нужд организации, либо для предоставления другим организациям за плату во временное владение и пользование, или во временное пользование. К ним относятся здания, сооружения, машины, оборудование и транспортные средства, культивируемые биологические ресурсы и другие виды основных фондов.

Коэффициент обновления основных фондов - отношение стоимости основных фондов, введенных в действие в течение года, к их наличию на конец года по полной учетной стоимости, в процентах. Показатель отражает удельный вес вновь введенных за год основных фондов в общем объеме этих фондов. 
Коэффициент выбытия основных фондов - отношение ликвидированных за год основных фондов к их наличию на начало года по полной учетной стоимости, в процентах. Данный показатель, наряду с коэффициентом обновления, характеризует интенсивность процесса обновления основных фондов.

Износ основных фондов - частичная или полная утрата основными фондами потребительских свойств и стоимости в процессе эксплуатации, под воздействием сил природы и вследствие технического прогресса.

Степень износа основных фондов - отношение накопленного к определенной дате износа имеющихся основных фондов (разницы их полной учетной и остаточной балансовой стоимости) к полной учетной стоимости основных фондов на ту же дату, в процентах.

В табл. 3.11 - 3.16 информация приведена по данным формы № 11 «Сведения о наличии и движении основных фондов (средств) и других нефинансовых активов».

\section{СТРОИТЕЛЬСТВО И РЫНОК ЖИЛЬЯ}

\section{Строительство жилья и коммунальных объектов}

Раздел содержит статистические материалы, характеризующие состояние и динамику жилищного и коммунального строительства: ввод в действие жилых домов, объектов коммунального хозяйства.

Общая площадь жилых домов определяется как сумма площадей всех частей жилых помещений, включая площадь помещений вспомогательного использования, предназначенных для удовлетворения гражданами бытовых и иных нужд, связанных с их проживанием в жилом помещении, площадей лоджий, балконов, веранд, террас, подсчитываемых с соответствующими понижающими коэффициентами, а также жилых и вспомогательных помещений в построенных населением индивидуальных жилых домах. К помещениям вспомогательного использования относятся кухни, передние, холлы, внутриквартирные коридоры, ванные или душевые, туалеты, кладовые или хозяйственные встроенные шкафы. В домах-интернатах для престарелых и инвалидов, ветеранов, специальных домах для одиноких престарелых, детских домах к подсобным помещениям относятся столовые, буфеты, клубы, читальни, спортивные залы, приемные пункты бытового обслуживания и медицинского обслуживания.

В общую площадь введенных жилых домов не входит площадь вестибюлей, тамбуров, лестничных площадок, лифтовых холлов, общих коридоров, а также площадь в жилых домах, предназначенная для встроено-пристроенных помещений.

Число построенных квартир включает число квартир в законченных строительством жилых домах квартирного, гостиничного типа и общежитиях, квартиры в нежилых зданиях, а также в построенных населением индивидуальных жилых домах.

Средняя фактическая стоимость строительства 1 м $^{2}$ общей площади жилых помещений во введенных в эксплуатацию жилых зданиях определяется как сумма фактически произведенных застройщиками капитальных затрат, приходящихся на $1 \mathrm{~m}^{2}$ общей площади всех законченных строительством за год жилых домов (без пристроек, надстроек, встроенных помещений и без жилых домов, построенных индивидуальными застройщиками), независимо от даты начала строительства и степени комфортности, этажности, включая дома, строительство которых осуществлялось с нарушением нормативных сроков.

Данные по вводу в действие объектов коммунального хозяйства приведены за счет строительства и реконструкции. 


\section{Рынок жилья}

Раздел содержит статистические материалы о приватизации, продаже жилищного фонда и приобретении квартир на рынке жилья.

К сделкам с жилым фондом относятся: купля-продажа, наем, аренда, обмен, приватизация, дарение, наследование жилого фонда. Содержанием посреднических услуг в сделках с жилым фондом является: подбор вариантов, оформление всех необходимых для совершения сделки документов, консультирование юристами и агентами фрирм участников сделки по возникающим проблемам.

Комплексное наблюдение условий жизни населения организовано во исполнение постановления Правительства Российской Федерации от 27 ноября 2010 года № 946 «Об организации в Российской Федерации системы федеральных статистических наблюдений по социально-демографическим проблемам и мониторинга экономических потерь от смертности, заболеваемости и инвалидизации населения».

В 2011 году Комплексное наблюдение условий жизни населения проводилось органами государственной статистики во всех субъектах Российской Федерации по выборочному методу с охватом 10 тысяч домохозяйств и строилось на принципе их добровольного участия.

Комплексное наблюдение условий жизни населения осуществляется на основе личного опроса членов домашних хозяйств (респондентов) по месту их проживания в составе отобранного для наблюдения домохозяйства.

При проведении Комплексного наблюдения условий жизни населения личному опросу подлежат респонденты в возрасте 15 лет и старше, установленные в составе домохозяйства, за исключением лиц, отсутствующих на момент проведения опроса, и лиц, не имеющих возможности дать информацию за себя лично по состоянию здоровья, в силу преклонного возраста и т.п.

Начиная с 2014 года указанное наблюдение проводится один раз в 2 года с охватом 60 тысяч домохозяйств.

Задолженность по жилищным кредитам в рублях и иностранной валюте, предоставленным физическим лицам - остаток задолженности (включая просроченную) на начало года по кредитам, предоставленным кредитными организациями фризическим лицам-резидентам Российской Федерации на приобретение и обустройство земли под жилищное строительство (земельный кредит); для финансирования строительных работ (строительный кредит); на приобретение жилья.

Задолженность по ипотечным жилищным кредитам в рублях и иностранной валюте - остаток задолженности (включая просроченную) по жилищным кредитам, предоставленным физическим лицам под залог недвижимости в порядке, установленном Федеральным законом от 16.07.1998 № 102-Ф3 «Об ипотеке (залоге недвижимости)».

\section{ИНВЕСТИЦИИ И ФИНАНСОВОЕ СОСТОЯНИЕ ЖИЛИЩНО-КОММУНАЛЬНОГО ХОЗЯЙСТВА}

\section{Инвестиции в жилищно-коммунальное хозяйство}

Инвестиции в основной капитал - совокупность затрат, направленных на строительство, реконструкцию (включая расширение и модернизацию) объектов, которые приводят к увеличению их первоначальной стоимости, приобретение машин, оборудования, транспортных средств, производственного и хозяйственного инвентаря, бухгалтерский учет которых осуществляется в порядке, установленном для учета вложений во внеоборотные активы, инвестиции в объекты интеллектуальной 
собственности, культивируемые биологические ресурсы.

Инвестиции в основной капитал по жилищно-коммунальному хозяйству показаны исходя из назначения основных средств, т.е. той сферы деятельности, в которой они будут функционировать.

Инвестиции в основной капитал учитываются без налога на добавленную стоимость. Индексы физического объема инвестиций в основной капитал рассчитаны в сопоставимых ценах. В качестве сопоставимых приняты среднегодовые цены предыдущего года.

Прямые инвестиции - это категория трансграничных инвестиций, при которой резидент одной страны осуществляет контроль (более чем 50 \% голосов в управлении) или имеет значительную степень влияния (от $10 \%$ до $50 \%$ ) на управление предприятием, являющимся резидентом другой страны.

\section{Финансовое состояние организаций жилищно-коммунального хозяйства}

Сальдированный финансовый результат (прибыль минус убыток) - конечный финансовый результат, выявленный на основании бухгалтерского учета всех хозяйственных операций организаций. Представляет собой сумму прибыли (убытка) от продажи товаров, продукции (работ, услуг), основных средств, иного имущества организаций и доходов от прочих операций, уменьшенных на сумму расходов по этим операциям. Данные по сальдированному финансовому результату деятельности организаций приводятся без субъектов малого предпринимательства в фактически действовавших ценах, структуре и методологии соответствующих лет.

Финансовая устойчивость организаций характеризуется состоянием финансовых ресурсов, обеспечивающих бесперебойный расширенный процесс производства и продажи продукции на основе роста прибыли.

Основными показателями финансовой устойчивости организаций являются следующие коэффициенты: коэффициент автономии, характеризующий долю собственных средств в общей величине источников средств организаций и определяющий степень независимости от кредиторов; коэффициент обеспеченности собственными оборотными средствами, который рассчитывается как отношение собственных оборотных средств к фактической стоимости всех оборотных средств, находящихся в наличии у организаций.

Платежеспособность характеризует возможности организаций своевременно расплачиваться по своим обязательствам.

Одним из показателей платежеспособности организаций является коэффициент текущей ликвидности, рассчитываемый как отношение фактической стоимости находящихся в наличии у организаций оборотных средств к наиболее срочным обязательствам организаций в виде краткосрочных кредитов и займов, кредиторской задолженности.

Суммарная задолженность по обязательствам организаций включает кредиторскую задолженность, задолженность по кредитам банков и займам.

Кредиторская задолженность включает задолженность по расчетам с поставщиками и подрядчиками за поступившие материальные ценности, выполненные работы и оказанные услуги, в том числе задолженность, обеспеченную векселями выданными; задолженность по расчетам с дочерними и зависимыми обществами по всем видам операций; с рабочими и служащими по оплате труда, представляющую собой начисленные, но невыплаченные суммы оплаты труда; задолженность по отчислениям на государственное социальное страхование, пенсионное обеспечение и медицинское страхование работников организаций, задолженность по всем видам платежей в бюджет и внебюджетные фонды; задолженность организаций по платежам по обязательному и добровольному страхованию имущества и работников организаций и другим видам 
страхования, в которых организация является страхователем; авансы полученные, включающие сумму полученных авансов от сторонних организаций по предстоящим расчетам по заключенным договорам, а также штрафы, пени и неустойки, признанные организацией или по которым получены решения суда (арбитражного суда) или другого органа, имеющего в соответствии с законодательством Российской Федерации право на принятие решения об их взыскании, и отнесенные на финансовые результаты организаций.

Дебиторская задолженность включает задолженность по расчетам с покупателями и заказчиками за товары, работы и услуги, в том числе задолженность, обеспеченную векселями полученными; задолженность по расчетам с дочерними и зависимыми обществами; суммы уплаченных другим организациям авансов по предстоящим расчетам в соответствии с заключенными договорами; задолженность по расчетам с прочими дебиторами, включающая в себя задолженность финансовых и налоговых органов (в том числе по переплате по налогам, сборам и прочим платежам в бюджет); задолженность работников организации по предоставленным им ссудам и займам за счет средств этой организации или кредита (ссуды на индивидуальное и кооперативное жилищное строительство, приобретение и благоустройство садовых участков, беспроцентные ссуды молодым семьям на улучшение жилищных условий или обзаведение домашним хозяйством и др.); задолженность подотчетных лиц; поставщиков по недостачам товарно-материальных ценностей, обнаруженным при приемке; задолженность по государственным заказам, фредеральным программам за поставленные товары, работы и услуги, а также штрафы, пени и неустойки, признанные должником или по которым получены решения суда (арбитражного суда) или другого органа, имеющего в соответствии с законодательством Российской Федерации право на принятие решения об их взыскании, и отнесенные на финансовые результаты организации.

Просроченная задолженность - задолженность, не погашенная в сроки, установленные договором.

Финансовые вложения организаций - инвестиции организации в государственные и муниципальные ценные бумаги, ценные бумаги других организаций, в том числе долговые ценные бумаги, в которых дата и стоимость погашения определена (облигации, векселя); вклады в уставные (складочные) капиталы других организаций (в том числе дочерних и зависимых хозяйственных обществ); предоставленные другим организациям займы; депозитные вклады в кредитных организациях; дебиторская задолженность, приобретенная на основании уступки права требования, вклады организации-товарища по договору простого товарищества и пр.

Накопленные финансовые вложения - объем накопленных фринансовых вложений, произведенных юридическим лицом с начала их вложения с учетом их изъятия и выбытия в отчетном периоде

Финансовые вложения, осуществленные организацией, в зависимости от срока погашения займов и кредитов подразделяются на долгосрочные и краткосрочные.

Долгосрочные финансовые вложения - вложения, осуществленные на срок более одного года с намерением получения доходов (дивидендов): инвестиции организации в доходные активы (ценные бумаги) других организаций, уставные (складочные) капиталы других организаций, созданных на территории Российской Федерации или за ее пределами, государственные ценные бумаги (облигации и другие долговые обязательства) и т.п., а также предоставленные организацией другим организациям займы. 
Краткосрочные финансовые вложения - вложения на срок не более одного года, осуществленные с намерением получения доходов (дивидендов): в дочерние и зависимые организации, инвестиции организации в ценные бумаги других организаций, государственные ценные бумаги, и т.п., а также предоставленные другим организациям займы на срок не более одного года и пр.

В таблицах приведены данные о ведомственной отчетности Министерства финансов Российской Федерации по статье «Жилищно-коммунальное хозяйство».

Бюджет - форма образования и расходования денежных средств, предназначенных для фринансового обеспечения задач и функций государства и местного самоуправления.

Бюджетная система Российской Федерации - основанная на экономических отношениях и государственном устройстве Российской Федерации, регулируемая законодательством Российской Федерации совокупность федерального бюджета, бюджетов субъектов Российской Федерации, местных бюджетов и бюджетов государственных внебюджетных фондов.

Консолидированный бюджет - свод бюджетов бюджетной системы Российской Федерации на соответствующей территории (за исключением бюджетов государственных внебюджетных фондов) без учета межбюджетных трансфертов между этими бюджетами.

Консолидированный бюджет Российской Федерации образуют федеральный бюджет и свод консолидированных бюджетов субъектов Российской Федерации (без учета межбюджетных трансфертов между этими бюджетами).

Бюджет субъекта Российской Федерации (региональный бюджет) - предназначен для исполнения расходных обязательств субъекта Российской Федерации. Бюджет субъекта Российской Федерации и свод бюджетов муниципальных образований, входящих в состав субъекта Российской Федерации (без учета межбюджетных трансфертов между этими бюджетами), образуют консолидированный бюджет субъекта Российской Федерации.

Доходы бюджета - поступающие в бюджет денежные средства, за исключением средств, являющихся в соответствии с Бюджетным кодексом Российской Федерации источниками финансирования дефицита бюджета.

Расходы бюджета - выплачиваемые из бюджета денежные средства, за исключением средств, являющихся в соответствии с Бюджетным кодексом Российской Федерации источниками финансирования дефицита бюджета.

Расходы бюджетной системы Российской Федерации на жилищнокоммунальное хозяйство - финансирование мероприятий в области жилищного и коммунального хозяйства. 


\section{РЕАЛИЗАЦИЯ ПРОГРАМ В СФЕРЕ ЖИЛИЩНО-КОММУНАЛЬНОГО ХОЗЯЙСТВА}

\section{Реформа жилищно-коммунального хозяйства}

Выборочное обследование бюджетов домашних хозяйств проводится органами государственной статистики во всех субъектах Российской Федерации по выборочному методу, охватывает около 48,5 тыс. домашних хозяйств и строится на принципе их добровольного участия.

Для формирования выборочной совокупности домашних хозяйств применяется двухступенчатая случайная выборка, построенная по территориальному принципу, обеспечивающая получение репрезентативных итогов обследования в целом по России (по населению в целом и по основным социально-экономическим группам) и по субъектам Российской Федерации (по населению в целом).

Конечной единицей отбора является домохозяйство, представляющее собой совокупность лиц, проживающих в одном жилом помещении или его части, как связанных, так и не связанных отношениями родства, совместно обеспечивающих себя всем необходимым для жизни, полностью или частично объединяя и расходуя свои средства. Домохозяйство может состоять из одного человека, проживающего самостоятельно.

Программа обследования основывается на ведении в домохозяйстве записей о текущих расходах и опросе (интервьюировании) членов домохозяйства по окончании учетного периода обследования.

Потребительские расходы домашних хозяйств являются частью денежных расходов, которые направляются на приобретение потребительских товаров и услуг. В их составе не учитываются расходы на покупку произведений искусства, антиквариата и ювелирных изделий, приобретенных в качестве капиталовложений, оплату материалов и работ по строительству и капитальному ремонту жилых или подсобных помещений, являющихся инвестициями.

Субсидии на оплату жилого помещения и коммунальных услуг являются адресным видом социальной помощи и предоставляются гражданам органами исполнительной власти субъектов Российской Федерации и органами местного самоуправления в случае, если их расходы на оплату жилого помещения и коммунальных услуг, рассчитанные исходя из размера регионального стандарта нормативной площади жилого помещения, используемой для расчета субсидий, и размера регионального стандарта стоимости жилищно-коммунальных услуг, превышают величину, соответствующую максимально допустимой доле расходов граждан на оплату жилого помещения и коммунальных услуг в совокупном доходе семьи.

Расходы субъектов Российской Федерации на реализацию мер социальной поддержки отдельных категорий граждан - средства по расходным обязательствам субъекта Российской Федерации, предусмотренные законом о бюджете субъекта Российской Федерации и финансируемые из бюджета субъекта Российской Федерации и бюджетов муниципальных образований. Направленные на эти цели средства федерального бюджета не учитываются.

Социальная поддержка по оплате жилого помещения и коммунальных услуг предоставляется в соответствии с действующим законодательством определенным категориям граждан, в том числе совместно с ними проживающим членам их семей (если это предусмотрено соответствующим данной категории граждан законодательством) в виде скидки к начисленной сумме платежа за жилое помещение и коммунальные услуги или в виде денежной выплаты гражданину через банковские счета, организации связи или иным способом.

\section{МЕЖДУНАРОДНЫЕ СРАВНЕНИЯ}

В разделе по странам СНГ использована информация, предоставленная Межгосударственным статистическим комитетом Содружества Независимых Государств. 


\title{
ЖИЛИЩНОЕ ХОЗЯЙСТВО в РОССИИ. 2019
}

Статистический сборник

\author{
Ответственные за выпуск: \\ Н.С. Бугакова \\ И.В. Воронина \\ М.В. Максимова \\ Тел: (495) 607-4071 \\ $632-9224$ \\ $632-9225$
}

Компьютерная верстка Главного межрегионального центра обработки и распространения статистической информации Федеральной службы государственной статистики

Подписано 17.12.2019 г. 